\title{
V 1-1
}

\section{インドシアニングリーン蛍光法を利用し完全切除し得た肝芽睡 肺転移の 1 例}

○金田 真吏、長野 裕充、河合 宏、栃井 大輔、栃井 祥子、須田 隆、星川 康 藤田保健衛生大学 呼吸器外科

【はじめに】小児肝芽腫は一般に抗癌剤感受性が低く、完全切除の可否が予後に大きく影響する。多発肺転移を 有する症例でも原発巣および肺転移巣の完全切除後長期生存の報告が散見される。肝芽腫肺転移巣の切除にお いては、とりわけ触知困難な小病巣をいかに同定するかが重要とされている。今回、肝芽腫細胞への ICG（イ ンドシアニングリーン) 集積を利用した蛍光法により、小病巣を確実に同定し完全切除し得た症例を経験した ので報告する。【症例】 1 歳 2 か月女児。母親の妊娠高血圧症候群のため在胎 28 週 5 日で出生。出生体重 1053 $\mathrm{g}$ 。身長 $69 \mathrm{~cm}$ 、体重 $8.7 \mathrm{~kg}$ 。4 日間持続する $38 \sim 40$ 度の発熱のため近医より当院小览科紹介。腹部膨満、AFP 440690 ( $\leqq 20 \mathrm{ng} / \mathrm{dl})$ 、造影 CT 上、肝右葉前区〜左葉を占める巨大な腫瘍を認め、肝芽腫と診断。化学療法 （CITI）を開始したが、腫瘍増大し多発肺転移が出現。CITA 2 コースの後 ITEC 3 コース施行し AFP は 9413 $\mathrm{ng} / \mathrm{ml}$ まで低下した。胸部 CT 上、肺野に 7 つの小結節を認めた(左舌区, 2 ; 左下葉 $\mathrm{S} 10,2$; 右中葉, 1 ; 右 下葉 S10, 2)。原発巣は非常に大きく、切除後生体肝移植を要する可能性があるため、肺転移巣が完全切除さ れたことを確認後、原発巣の手術を行う方針が選択された。手術は両側開胸肺部分切除術を施行。両肺下葉 $\mathrm{S}$ 10 の結節それぞれ 1 つずつは触診により同定できず、ICG 蛍光法により同定し切除することができた。術後第 3 病日まで人工呼吸管理を要したが軽快。術後第 12 病日化学療法を再開。胸部 CT 上、肺腫瘍遺残、新たな肺 転移巣出現を認めず。術後第 42 病日 肝 3 区域切除により原発巣を完全切除した。肝芽腫肺転移切除に掞ける 小転移巣同定法として ICG 蛍光法は有用である。 


\section{1-2}

\section{単孔式剣状突起下アプローチによる一期的両側肺転移巣切除を 施行した一例}

○河合 宏、須田 隆、星川 康、栃井 祥子、栃井 大輔、金田 真吏、長野 裕充 藤田保健衛生大学 呼吸器外科学

両側肺転移に対する手術は、両側側胸部アプローチにより行われるが、胁間神経障害がほぼ必発である。単 孔式剣状突起下アプローチによる両側肺切除は、胁間神経障害をきたすことなく一期的に両側肺にアプローチ できる低侵襲手術法である。今回我々は、肝細胞癌の多発両側肺転移に対して単孔式剣状突起下アプローチに よる一期的両側肺転移巣切除を施行した一例を報告する。症例は、33 歳の女性。2014 年肝細胞癌に対し拡大後 区域切除が施行された。2015 年 12 月原発巣の局所再発と両側多発肺転移を指摘され、肝動注化学療法により 局所再発巣のコントロールと多発肺転移の縮小が得られたが、経過観察中に多発肺転移巣の再増大を認めたた め、切除の方針とした。胸部 CT 上、右肺 $\mathrm{S} 6$ に径 $5 \mathrm{~mm}$ 、左肺 $\mathrm{S} 1+2$ に径 $5 \mathrm{~mm}$ 、左肺底部に径 $15 \mathrm{~mm}$ の結節 影を認めた。手術は、剣状突起下に約 $3 \mathrm{~cm}$ の縦切開を行った。 $8 \mathrm{cmH} 20$ の圧で $\mathrm{CO} 2$ を縦隔内に送気、両側の縦 隔胸膜を切開し両側開胸した。すべての腫瘍は臓側胸膜直下にあったため、モニター視とソラココットンによ る触診で、腫瘍の局在同定が可能であった。右肺 S6 腫瘍の切除にやや難啮したが、手術台を傾けるなどの工夫 により、それぞれステイプラーを用いて肺部分切除を施行できた。術後第 3 病日に合併症なく退院となった。 近年、剣状突起下からの単孔式肺葉切除も報告されている。肺切除のための剣状突起下アプローチは、側胸部 アプローチではほほ必発である肋間神経障害を避けることができるため、さらに重要な術式となる可能性があ る。今後、手術の操作性の改善が望まれる。 


\section{1-3}

\section{肺門前方からアプローチし胸腔鏡下に舌区+S8 区域切除をし 得た中咽頭癌肺転移の 1 例}

○佐伯 祐典'、後藤 行延? 、荒木 健太郎? 、上田 翔'、北沢 伸祐?、鈴木 久史?、小林 尚寛? 菊池 慎二'、市村 秀夫'、佐藤 幸夫'、大和 万里子? 、坂下 信悟?、野口 雅之' 1筑波大学 呼吸器外科、2筑波大学 病理診断科

舌区域切除術において、分葉不全で葉間から肺動脈にアプローチが困難な場合、肺門前方からのアプローチ が必要になるが、視野展開に難渋する。今回、左肺 S4 と S8 にまたがる腫瘍に対し、葉間からのアプローチが 困難であったが、胸腔鏡下に肺門前方からのアプローチで良好な視野にて舌区 $+\mathrm{S} 8$ 区域切除を施行し得た 1 例を経験したので報告する。

【症例】 67 歳男性。6 3 歳時に中咽頭癌に対して前医にて放射線化学療法施行し CR が得られていた。フォロー の PET/CT で左肺 S4 と S8 にまたがる結節影を認め、肺転移再発が疑われた。本人の希望により手術の方針と なった。胸腔鏡下舌区 $+\mathrm{S} 8$ 区域切除術施行。葉間にまたがる腫瘍で、葉間からのアプローチが困難であったた め、肺門前方よりアプローチした。V4+5、A4+5(縦隔型)、舌区域気管支の順に処理し、葉間へ到達。上大区 と舌区の区域間は過分葉があり、それに沿って自動縫合器で区域間を作成し上舌区間を分離した。続いて舌区 を尾側へ脱転し、A8、B8、V8 を処理し、B8 断端から送気し区域間を描出し自動縫合器で区域間を作成し、舌 区 $+S 8$ 区域切除を完了した。術後経過良好で術後 7 日目に退院となった。病理結果は扁平上皮癌で中咽頭癌の 肺転移に矛盾しない所見であった。 


\section{1-4}

\section{両側続発性気胸に対し両側同時胸腔鏡下手術時に発生した火災 の 1 例}

○江里口 大介1、中嶋 英治'、高橋 秀暢 $、$ 三浦 弘之'、池田 徳彦²

'東京医科大学八王子医療也ン夕一呼吸器外科、 2 東京医科大学 呼吸器外科学分野

【はじめに】術中の火災は、患者に致命的な障害を与える可能性がある。呼吸器外科手術では分離肺換気で高濃 度酸素を用いるため、電気メスやレーザー装置使用時、火災には注意が必要である。今回、我々は両側同時胸 腔鏡下手術を施行時に発生した火災を経験したので報告する。【症例】70 代、男性。呼吸困難を主訴に両側続 発性気胸と診断、加療目的で入院となった。胸腔ドレナージ施行後も両側の肺漏が遷延し、両側同時胸腔鏡手 術の方針とした。肺漏が著明だった左側を先行し問題なく終了、次いで右側の手術へと移行した。右肺は分離 肺換気下でも緊満した肺囊胞が中央に存在し、視野の確保が困難であった。切除予定の肺囊胞であったため、 電気メスで囊胞壁を焼灼し孔を開け、縮ませて視野の確保を試みた途端にソラコポートが然焼した。直ちに ポートを抜去し、患者に障害は来さなかった。その後は問題無く手術は終了し、術後経過も良好、第 21 病日に 退院となった。【考察】胸腔鏡下手術では、緊満した肺襄胞が存在する場合、視野、手術の妨げになる。切除す る肺囊胞であれば縮ませて術野を確保する場合があるが、術前挿管時に高濃度酸素で換気をしており、緊満し た肺囊胞内にも高濃度酸素が存在する可能性に留意すべきである。本症例では両側気胸の手術で対側施行後で あり、片側手術中に分離肺換気のために対側肺の肺囊胞に高濃度酸素が充満し、また肺漏により胸腔内にも高 濃度酸素が充満していた可能性があった。こうした状況での電気メス使用によりソラコポートに発火したと考 えられた。結語】肺囊胞を破り縮ませる際には電気メスの使用は避け、針や剪刀、尖刃を用いるべきである。 


\section{1-5}

\section{自然気胸手術におけるネオベールシート+サージセルシート貼 付法の有用性}

○渡邊 拓弥、横田 圭右、深井一郎

$J A$ 三重厚生連鈴鹿中央総合病院 呼吸器外科

自然気胸に対する手術成績向上には、ステイプラーライン近傍からのブラ新生による再発予防が重要な因子 となる。その対策として、酸化セルロースシート (サージセルシート) やポリグリコール酸シート（PGA シー ト、ネオベールシート)の貼付が普及している。両者とも臓側胸膜の肥厚を促す目的で使用されるが、ポリグ リコール酸シートは炎症をより強く惹起し、吸収されるまでの時間が、酸化セルロースシートよりもはるかに 長いため、臟側胸膜の肥厚をより強く促し、ブラ新生を抑制する力はより強い。しかし、その性質が故に壁側 胸膜との強固な癒着をもたらし、再手術の際には操作を困難にする要因にもなる。一方、酸化セルロースシー トは胸壁との癒着をほとんど生じない。当科は、両者の利点を加味するため、ポリグリコール酸シート貼付し、 それに重ねて酸化セルロースシートを置いている。再発率は約 $1.6 \%$ であり、良好な成績を得ている。再手術 を要した症例では胸膜の十分な肥厚を得ていた上に、胸壁との癒着は皆無であった。ポリグリコール酸シート のみで対処された症例の再発時所見も供覧し、本法の有用性を報告する。 


\section{1-6}

\section{気腫性肺に対してリンフォースカートリッジを使用した 20 例 の検討}

○渡邊 譲、井上 卓哉、松村 勇輝、管野 隆三 福島赤十字病院

気腫性肺は肺が脆弱なため、肺切除を行った際に術後の気漏遷延が懸念される。エンド GIA トライステープ ルリンフォースカートリッジは自動縫合器にポリグリコール酸（PGA）を材料とした吸収性縫合補強材があら かじめ装着されており、脆弱な肺組織においてステープルライン全体を補強し、組織の裂傷による気漏防止が 期待できるデバイスである。当院では 2015 年 6 月より気腫性肺を合併した 20 例の肺切除にリンフォースカー トリッジを使用した。症例の内訳は続発性気胸が 12 例、巨大ブラが 3 例、肺癌が 5 例であった。年齢は平均 65 歳（31-92 歳)、男性 19 例、女性 1 例、喫煙指数は平均 887 （110-1800）であった。カートリッジの平均使 用個数は 1.6 個 (1-3 個)、平均手術時間は 90.2 分 (49-236 分) であった。術後に気漏を認めたのは 3 例で、 1 例は保存的に停止し、もう 1 例は再開胸したところリンフォース使用部位とは別の部分からの気漏であった。 もう 1 例は術後 2 日目に胸膜癒着術を施行し気漏が停止した。術後平均在院日数は 12.8 日（4-35 日）であっ た。術後の観察期間は 1 ヶ月 -1 年 5 ヶ月（中央值 1 年 2 ケ月）で現在までに全例で気漏の再発を認めていな い。また、巨大ブラの 1 例はブラの基部が肺動脈に近接しており、一部ブラ壁でステープリングして切除した が、術後に気漏を認めず、退院後も再発なく経過している。気腫性肺を合併した肺切除に対してエンド GIA トライステープルリンフォースカートリッジは有用なデバイスと考えられる。 


\section{1-7}

\section{気瘻部位の特定における Dynamic Volume Scan の有用性}

○小澤 広輝'、大井 諭'、伊藤 靖1、松下 晃三²、鈴木 一也 ${ }^{2}$

磐田市立総合病院 呼吸器乳腺外科、 ${ }^{2}$ すすかけセントラル病院 呼吸器外科

【はじめに】高齢者や様々な合併症を持った気胸において, 治療に難渋する例が多い. Dynamic Volume Scan が気瘻部位の特定において有用であった症例を報告する.【症例】 80 歳, 男性. 体動困難を主訴に当院へ救急 搬送された. 精查の結果, 両側気胸, 縦隔気腫, 間質性肺炎, 高 CRP 血症で, 呼吸器内科に入院となった. 気 胸は軽度であったため, 胸腔ドレナージは施行されずに経過観察となっていたが, 第 2 病日に右気胸の悪化を 認めたため, 胸腔ドレナージを施行された. エアリークの改善が全くないため, 当科にコンサルトとなった. 第 14 病日に胸腔造影と Dynamic Volume Scan を行い, 右 S2 のブラからエアリークを認めた. 第 19 病日に局 所麻酔下胸腔鏡下右肺囊胞被覆術を施行した. 2 ポートで手術を施行した. 多数の癒着を認めたが, 術前の画 像検査で原因部位と考えた位置まで到達することができ，エアリークを認めた．PGA sheetと Bolheal を使用 し, 重層的に被覆した，被覆を行うと，術中の視野確保が困難になるほどに，肺の拡張傾向を認める様になっ た，術後は順調にドレーンを抜去することができ，右気胸の再発を起こすことは無かった。しかし，間質性肺 炎や高 CRP 血症の遷延などによって全身状態が日ごとに悪化し, 第 32 病日に急変し, 永眠となった.【考察】 Dynamic Volume Scan によって, 立体的に病変を把握する助けになった，それによって，有効なポート位置の 選択や手術時間の短縮につながり、全身状態不良の患者さんに対しても手術アプローチの可能性が拡がると考 えられた，画像を供覧しながら報告する． 


\title{
V1-8
}

\section{巨大気腫性肺囊胞に対する遷延性気漏防止のための手技一'Ta- chosuture' technique一の応用}

\author{
○竹内 千枝、西田 達、三上 厳、藤井 祥貴
}

石切生喜病院 呼吸器外科

【緒言】Tachosuture’ technique は、肺切除の際に生じた胸膜欠損部にシート状生物学的組織接着剂 (TachoSil) を貼付した後、吸収糸で肺への縫着を追加することにより、シートの脱落を防ぎ、術後の遷延性気漏を回避す るための手技である [Gen Thorac Cardiovasc Surg, in press]。今回我々は、巨大気腫性肺囊胞に対しても同手 技が有効であった症例を経験したので、ビデオで供覧する。【症例】54 歳女性。長引く咳嗽を主訴に近医受診、 胸部 CTにて気胸を伴う左巨大気腫性囊胞を指摘され、当科紹介となった。紹介時に自然閉鎖が得られ気胸は 改善していたが、左胸痛を繰り返していたため、待機的手術として、3カ月後に完全鏡視下手術(Thoracoscopic surgery：TS）を行った。術前呼吸機能は、VC 2.891，\%VC 112.0\%, FEV1 2.371, FEV1\% 79.0\%であった。 【手技】片側倒立させた対面式モニターを設置し、4 力所のポート（15mm）でTSを行った。まず巨大襄胞を 切開して内腔を確認した後、囊胞壁の天床部分を切除して囊胞底面を露出し、囊胞底面全体に TachoSil を貼付 した。その際、切り残した囊胞壁や周囲の健常組織にもシートが及ぶようにサイズを調整した。調整したTachoSil を残存囊胞壁と健常組織にまでかかるように貼付した後、5-0 PDS-II で縫着した。水封試験で気漏がな いことを確認し TS を終了。術後は気漏を認めず、1POD に胸腔ドレーン抜去、5POD に退院となった。【結語】 ‘Tachosuture’ technique は、巨大気腫性肺囊胞に対しても簡便で有効な手技である。 


\section{V2-1}

\section{壁側・䁍側胸膜の全面癒着を認めた悪性胸膜中皮腫に対する胸 膜切除/肺剥皮術の一例}

○伊藤 謙作 ${ }^{1} 、$ 田川 哲三1、木下 郁彦1、増野 智章?、藤崎 秀明?、重永 武彦? 、本廣 昭 1 '大分赤十字病院 呼吸器外科、 ${ }^{2}$ 大分赤十字病院 呼吸器内科

63 歳男性。検診胸写異常にて当院受診、胸部 CTにて左胸水、胸膜肥厚を認めた。胸膜生検にて悪性胸膜中 皮腫 (上皮型、cT1N0M0 stageIA) と診断され、術前導入化学療法 (シスプラチン+ペメトレキセド 3 コース) を施行した。左胸水は減少したが胸膜肥厚は著変なくSDの判定であった。胸膜切除/肺剥皮術の方針として手 術に臨んだ。左後側方切開、第 7 肋骨切離を行い胸膜外腔へ至り、胸膜外剥離を進めた。壁側胸膜は胸壁への 浸潤を認めず、剥離は比較的容易であった。胸腔鏡検查時のポート部は胸壁全層で切離した。心膜の一部およ び横隔膜腱中心は剥離できず合併切除を行った。壁側胸膜の剥離を完了後、臓側胸膜の剥離を行うために壁側 胸膜を切開し胸腔内に至ったが、胸腔内で全面癒着を認めた。壁側・臓側胸膜の癒着を剥離するのは困難で あったため、癒着したまま下葉 S8 りり臓側胸膜の剥離を進めた。下葉の剥離は容易であったが、上葉の剥離は 困難で、度々肺実質を損傷した。舌区の一部は剥離不能であったため肺部分切除を行った。全肺の臓側胸膜剥 離を完了したのち、肺損傷部を可及的に縫合修復し、フィブリン糊および PGA シートをVA 法にて肺損傷部 に貼付した。胸垫ドレーンを 2 本留置し手術を終了した。術後は軽度リークを認めるのみですぐに消失、術後 6 日で胸腔ドレーンを抜去した。重篤な術後合併症なく術後 25 日で療養転院した。臟側胸膜剥離を行う際に、 壁側胸膜を切開し胸腔内側より臓側胸膜にアプローチすることで剥離を容易に行える。本症例では壁側・臓側 胸膜が全面癒着していたが、二層が接着したまま操作することで比較的容易に剥離できたことをどデオにて供 覧する。 


\section{V2-2}

\section{同時発見された右悪性胸膜中皮腫と左肺癌に対し、右胸膜切除/ 肺剥皮術と VATS 左上区切除を行った 1 例}

○今西 直子、由良 讶希子、小林 健一、松宮 弘喜、金山 雅俊、名部 裕介、平良 彰浩、 篠原 伸二、桑田 泰治、竹中 賢、岡 壮一、近石 泰弘、平井 文子、田嶋 裕子、黒田 耕志、 田中 文啓

産業医科大学 第2外科

表題のような症例報告はなく、本症例が 1 例目と思われる。胸膜切除/肺剥皮術 Pleurectomy/Decortication (P/D) は、胸膜肺全摘 Extra Pleural Pneumonectomy（EPP）と比較して、肺瘦に関連するもの以外の重大な 合併症は少なく、肺機能を温存できることから、近年、選択される機会が増えている。【症例】69才男性、ア スベストの職業暴露あり。呼吸苦にて受診し、CT で右胸水と胸膜肥厚、左上区 GGO を認め、胸腔鏡及び気管 支鏡にて、右悪性胸膜中皮腫と左肺腺癌と診断された。切除希望にて当院紹介。【手術】VATS 左上区切後 28 日目に、右 $\mathrm{P} / \mathrm{D}$ を施行した。第 4 肋間アプローチ、心膜横隔膜合併切除再建、奇静脈合併切除、胸壁合併切除 (生検ポート部への腫瘍浸潤、第 7.8 肋骨) となった。満足な $\mathrm{P} / \mathrm{D}$ が行えなければ $\mathrm{EPP}$ へ術式変更する予定で あり、主肺動脈をターニケットでクランプしつつ、臟側胸膜の剥皮を行った。これにより、EPP となった場合 の心負荷への耐性を確認するとともに、肺実質からの出血コントロールに役立ったと思われる。手術時間 6 ： 30、出血量 $1600 \mathrm{ml}$ (胸水含む)、 $\mathrm{RBC}$ 輸血 4 単位【経過】肺㾞は漸減消失し POD10 全ドレーン抜去、POD30 退院した。前医にて術後化学療法 CDDP+PEM を6クール施行したのち、明らかな再発なく経過観察中であ る。【病理】悪性胸膜中皮腫 二相性 pT3N0M0, 高分化肺腺癌 pTlbN0M0【まとめ】本症例では、P/D の選 択により対側肺癌に手術のチャンスが生じ、また肺癌を胸腔鏡下に手術することで、两側胸郭の広範な破壊を 回避した。P/D と区域切除はいずれも肺血管床の温存に寄与した。 


\section{V2-3}

\section{後側方切開後の難治性肩甲骨下膿瘍に対する既離断広背筋を用 いた筋弁充填術}

○泉 信博、月岡 卓馬、小松 弘明、岡田 諭志、戸田 道仁、原 幹太朗、伊藤 龍一、花田 庄司、 西山 典利

大阪市立大学医学部 呼吸器外科

【背景】肩甲骨下膿瘍の原因としては胸腔内感染症，肩甲骨骨髄炎，後側方切開による胸部手術後の創感染また はガーゼ遺残によるものが知られており，その治療法は切開排膿や壊死物質の除去とされている. しかし肩甲 骨が骨性胸郭上を滑る特性を持つことから, 肩甲骨下に一定の空間が生じた場合, 肩甲骨下膿瘍は難治性にな ると考えられる. 今回難治性肩甲骨下膿瘍に対し, 後側方切開で過去に切断した広背筋で筋弁を作成し, 前鋸 筋下経由で肩甲骨下に充填し良好な結果を得た症例を経験したので報告する.【症例】症例は 74 歳男性。脳梗 塞子防のため抗血小板薬内服中. 2001 年に右肺上葉扁平上皮癌に対し、放射線療法（60Gy）拈よび化学療法 $(\mathrm{CDDP}+\mathrm{VP}-16: 2$ コース) 施行後、後側方開胸にて右肺上葉 sleeve 切除術施行。以降再発なく経過していた が、2011 年原因不明の肩甲骨下膿瘍 (血腫)に対し膿瘍切除掞よび肋間縫合糸・第 3 骨片除去術を施行. 一時 期軽快していたが, 2014 年血腫が再発し, 膿瘍择爬術施行. 以降感染を併発しドレーン留置, 洗浄拉よびデブ リードマンを繰り返した，画像診断では肩甲骨下に死腔を認め，難治性の原因と考えた．再発後 1 年目で広背 筋弁充填による根治術を施行した，術中に indocyanine green 蛍光血管造影による広背筋弁の血流評価を行 い, 離断部末梢も血流が維持されていることを確認した，術後 1 年経過し再発を認めていない.【結語】 14 年前に離断した広背筋を筋弁として肩甲骨下に充填し, 肩甲骨下膿瘍を治癒せしめた，肩甲骨下膿瘍に対する 2 回の手術をビデオで供覧する. 


\title{
V2-4
}

\section{肺温存術を行った一側胸腔全体を占拠する Chronic expand- ing hematoma $の 1$ 例}

\author{
$\bigcirc$ 三和 健、城所 嘉輝、窪内 康晃、万木 洋平、若原 誠、荒木 邦夫、谷口 雄司、中村 廣繁 \\ 鳥取大学医学部附属病院胸部外科
}

症例は 40 代男性、主訴は胸部異常影。2011 年の検診で左胸水貯留を指摘されるも無症状で受診せず。呼吸 困難増強し、2015 年の検診でも指摘され呼吸困難も強く前医受診。精査で左胸腔を占拠する腫瘤を認め、当院 内科紹介。SFT などを疑いエコーガイド下生検を予定するもエコーでは血流が豊富で生検は危険と判断され た。MRIにて慢性膨張性血腫 (Chronic expanding hematoma)を疑われて当科紹介となる。胸部 CT で左胸腔 内を占拠する $26 \times 16 \mathrm{~cm}$ の腫瘤を認め、左肺は縦隔側に圧排され、完全な無気肺となり、MRIでは T2 強調で モザイクパターンを呈し、左鎖骨下動脈の angiography で腫瘤の濃染や腫瘤に連続する異常血管は認めず。 FDG-PET では有意な集積は認めなかった。左胸腔内慢性膨張性血腫の診断で手術を施行した。手術は術中の 血行動態や出血時の迅速な心囊へのアプローチを考慮して胸骨正中切開でアプローチ、セルセーバーをスタン バイした。腫瘤は壁が肥厚し、強固に壁側胸膜、肺と癒着していた。内部の血腫を適宜吸引除去しながら第 4 肋間、第 8 肋間開胸を追加して剥離を進め、左肺との瘉着を剥離して肺を温存して腫瘤を完全に切除した。手

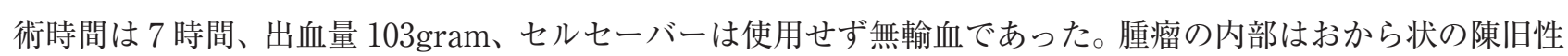
血腫が充満し、病理組織所見は器質化血腫で、腫瘍性病変は認めなかった。呼吸機能の改善を認め術後 1 年再 発なく経過観察中である。比較的稀な Chronic expanding hematoma の 1 切除例を経験したので、若干の文献 的考察を含めて報告する。 


\section{V2-5}

\section{胸腔鏡下に Total performance system を用いて切除した 傍骨性脂肪腫の一例}

○多々川 貴一、吳 哲彦、大久保 友人、喜田 裕介、横田 直哉、藤原 敦史、新居 和人、 松浦 奈都美、垂水 晋太郎、中島 成泰、中野 貴之、劉 大革、横見瀬 裕保

香川大学 呼吸器乳腺内分泌外科

【はじめに】診断未確定の胁骨腫瘍の手術において、近年胸腔鏡下での切除報告も散見されるが、TPSを用い た切除例は稀である。【症例】 33 歳男性。検診 X 線にて右上肺野に腫瘤影を指摘された。CT では右第 3 肋間 に $26 \mathrm{~mm}$ の胸腔内に突出する結節性病変を認め、 2 年間の観察で約 $0.5 \mathrm{~cm}$ の増大を認めたため切除目的に当院 紹介となった。骨シンチグラフィでは皮質の肥厚・破壊像は否定的であった。緩徐に増大している経過から傍 骨性脂肪腫を疑い、診断確定・治療のために胸腔鏡下で摘出手術を施行した。手術は仰臥位で 4 ポートを設置

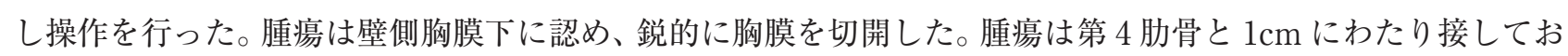
り剥離は困難であった。TPS を術者ポートから直線的に挿入し、腫瘍から $2 \mathrm{~cm}$ のマージンを設けて第 3,4 肋骨を切除、最終的に腫瘍と一塊にして摘出した。病理所見では成熟した脂肪細胞が増殖し、辺縁は骨組織で 覆われていたことより傍骨性脂肪腫と診断された。【考察】傍骨性脂肪腫は全脂肪腫の $0.5 \%$ 以下とされる稀な 腫瘍であり、胁骨に発生するものはさらに稀である。肋骨切除を伴う手術は、道具の煩雑さや手技の困難さか ら通常開胸手術で行われることが多い。TPS とは整形外科領域の手術で使用される電動式骨手術装置であ る。先端のデバイスを交換することで様々な大きさの骨切除に対応可能である。今回我々は TPSを用いること で、胁骨部分切除を伴う胸壁腫瘍摘出術を胸腔鏡下に完遂することができた。若干の文献的考察を加えて報告 する。 


\section{V2-6}

\section{甲状腺癌の胸骨柄および両側鎖骨頭転移の切除再建}

○西山 典利'、泉 信博'、月岡 卓馬 '、小松 弘明'、岡田 諭志'、戸田 道仁?、原 幹太朗? 伊藤 龍一'、花田 庄司 ${ }^{2}$

'大阪市立大学医学部 呼吸器外科、2東住吉森本病院 呼吸器外科

症例 : 63 歳、女性

既往歴：特記事項なし

現病歴： 22 年来、甲状腺腫大を指摘されていたが放置。 2 年前から増大傾向にあり、2016 年 4 月に前医を受診 した。超音波検查で甲状腺がんの頚部リンパ節転移、胸骨転移が疑われ、前澒部腫瘤、胸骨腫瘤からの穿刺吸 引細胞診でいずれも class V, papillary carcinoma と診断された。手術加療目的に当院に紹介され、CTでは甲 状腺右葉を圧排し、前澒部リンパ節、胸骨柄、両側鎖骨頭に一塊となった径約 $97 \mathrm{~mm}$ の転移性腫瘍を認めた。

手術 : 2016 年 7 月、甲状腺全摘出、頚部リンパ節郭清、胸骨柄、両側鎖骨頭合併切除、右内頸静脈部分合併切 除を施行した（乳腺内分泌外科、呼吸器外科、形成外科合同。手術時間 11 時間 56 分、出血 $780 \mathrm{ml}$ 、輸血 560 ml。呼吸器外科手術は 3 時間 46 分。）胸骨鎖骨の欠損は約 $10 \times 10 \mathrm{~cm}$ で、再建は GORE-TEX DUALMESH で胸骨鎖骨頭欠損部を補填 $(2-0$ Ethibond) したのち、有茎広背筋皮弁を被覆充填した。術後、人工呼吸管理 等は要さず、特に合併症もなく術後 14 日目に軽快退院した。

上肢機能 : 退院時は上肢挙上を 90 度までに制限していたが、外来にてリハビリを継続し、リハビリ開始後 2 か月程度で可動域制限はなくなるまでに回復した。

考察：胸壁補填には、有茎筋（皮）弁、胁骨、人工 Mesh 等が用いられるが、本症例のごとく、鎖骨を含めた 補填には強度の強い Dual Mesh は非常に有効であった。これまで当科では同様の胸骨欠損に Dual Mesh を 3 例に使用したが、いずれも感染等の合併症はなく、有用な材料であると思われた。 


\section{V2-7}

\section{成人漏斗胸に対し腹直筋有茎胸骨䧽転術を施行し心機能・ ADL の改善を認めた 1 例}

$\bigcirc$ 黒田 鮎美、福田 章浩、中道 徹、橋本 昌樹、多久和 輝尚、松本 成司、近藤 展行、長谷川 誠紀 兵庫医科大学 呼吸器外科

【はじめに】漏斗胸は心肺機能障害を呈するような高度な変形例は少なく、美容的、精神的な側面から手術適応 (相対的適応) となることが多い。また、心肺機能の改善を認めたとする報告も散見するが、多くは小児症例や Marfan 症候群の心臓との同時手術例であり、成人漏斗胸に対する手術で心機能、ADL が向上したとする報告 は少ない。【症例】39 歳男性。X 年 1 月 DOE 出現。9 月近医で心雑音を指摘、心エコーで severe MR と診断さ れた。11月当院心臓血管外科へ紹介となったが、当院検查では MR は軽度で、僧帽弁修復術では症状の改善を 見込めない可能性が高いと判断された。胸骨左縁で LEVINE3 度の収縮期雑音を聴取し、漏斗胸による右室流 出路狭窄の疑いとして 12 月当科へ紹介となった。術前 CT で Haller index $=4.38$ 、心電図で不完全右脚ブロッ クを認め、心エコーで mild MR を認めた。たこの頃には DOE のため休職し、長時間の立位保持も困難であっ た。 $\mathrm{X}+1$ 年 2 月、腹直筋有茎胸骨眽転術施行。術直後は症状の改善にそしかったが、術 4 日目の CT で心臓と 胸壁の接する距離の短縮を認め、Haller index は 3.42 に改善し、心電図で不完全右脚ブロックは認めなかっ た。3か月後の心エコーで MR は trivialに改善した。その後自覚症状も徐々に改善し、8 月月後には $10 \mathrm{~km}$ ランニングができるまで回復し、心エコーでも MR を認めなくなった。【まとめ】成人、非 Marfan の漏斗胸に 対し腹直筋有茎胸骨僠転術を施行し自覚症状の改善を認めた症例を経験した。手術ビデオ、術中の胸骨圧迫解 除時の径食道エコーを供覧し症例を提示する。 


\section{V3-1}

\section{第 4 胸椎浸潤肺癌に対する全椎体合併右上葉切除術}

$\bigcirc$ 蒲原 涼太郎、山崎 直哉、土谷 智史、松本 桂太郎、宮崎 拓郎、畑地 豪 長崎大学 腫瘍外科

椎体浸潤肺癌は、症例を選択した上で完全切除が可能であれば、長期生存が期待できることが報告されてい る。今回、第 4 胸椎浸潤肺癌に対して、導入化学放射線療法後に、第 3-5 全椎体合併切除・再建を伴う右上葉 切除術を施行した 1 例を経験した。若干の文献的考察を加えて報告する。症例は 49 歳女性。20XX 年 10 月背 部痛出現。20XX+1 年 1 月前医受診。CT において、気管および食道の背側かつ第 3-5 胸椎の腹側に長径 $4.9 \mathrm{~cm}$ の軟部腫瘤影を認め、さらに第 4 胸椎椎体内浸潤が疑われた。EBUS-TBNA で多形癌が検出された。肺と接し ていること、TTF-1 陽性であることから、縦隔型肺癌が疑われた。PET-CT では、既知病変に FDG の集積立 進を認め、その他に悪性病変を疑う所見はなかった。 $20 X X+1$ 年 2 月当院呼吸器内科紹介受診。臨床的に縦隔 型肺癌（cT4N0M0 stageIIIA）の診断で、術前導入化学放射線療法後に手術を行う方針とした。TS-1+CDDP 2 コースおよび放射線療法 $(40 \mathrm{~Gy} / 20 \mathrm{Fr})$ 完遂後の CT では、新病変の出現なく、効果判定は $\mathrm{SD}(4.9 \rightarrow 4.5 \mathrm{~cm}$; 縮小率 $8.2 \%$ ）であった。術前に血管造影を施行し、胁間動脈から分岐する腫瘍への栄養動脈塞栓術を施行し

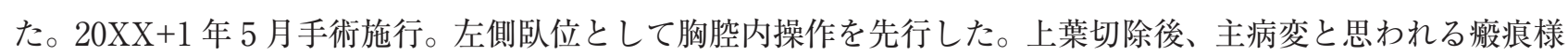
組織を椎体以外の組織から剥離して閉胸した。腹臥位に体位変換し、整形外科医師主導で第 3-5 椎体全切除お よび椎体固定術を施行した。手術時間 13 時間 01 分。出血量 $2805 \mathrm{ml}$ 。最終病理診断は瘏痕組織のみ(Ef 3 )。術 後は問題となる合併症は認めなかった。術後 27 日目に転院 (自宅退院は術後 56 日目)。術後 6 か月経過時した 点で無再発経過観察中である。 


\section{V3-2}

\section{胸壁浸潤を有する右上葉扁平上皮癌切除後の大腿竻膜を用いた 眴壁再建}

\section{○村 徹、清水 恵}

聖隷浜松病院 呼吸器外科

複数の肋骨浸潤を伴う非小細胞肺癌手術例では胸壁再建を要する場合が多く、多くの再建法が報告されてい る。しかし頻用される人工素材では術後感染がしばし問題となり、患者側に感染のリスクがある場合はその使 用は困難である。自己組織として各種筋弁の他に大腿筋膜も有用なオプションとされており、その有用性とし て遊離組織として使用可能であることや感染に強く強度も十分なこと、採取が簡便であること等が報告されて いる。今回我々は管理不良の糖尿病を合併した胸壁浸潤肺癌に対して大腿筋膜による胸壁再建を行った症例を 経験したので、その手技について報告する。症例は 70 歳男性。右背部痛の精査で撮影された胸部レントゲンで 右上葉の腫瘤影を指摘された。既往に糖尿病があり、近医でピオグリタゾンの内服治療を受けていたが $\mathrm{HbA}$ $1 \mathrm{c}=7.9 \%$ と管理不良であった。画像上病変は右上葉背側に存在し、第 5 、第 6 肋骨への浸潤を疑った。精査の 結果、扁平上皮癌（cT3（CW） NOM0）と判明し手術の方針となった。当院整形外科により腹臥位で第 4 - 第 6 横突起/肋骨頭切除後に左側臥位とし、右胸壁切除 (第 3 肋間筋 - 第 7 肋間筋) / 上葉切除/リンパ節郭清 ND $2 \mathrm{a}-1$ 施行。更に同体位で右大腿部に皮膚切開を加え、 $22 \times \mathrm{cm}$ 四方の大腿筋膜を採取し、これを用いて胸壁再 建を行い手術を終了した。術後経過は順調で第 15 病日に退院となった。術後約 1 ケ月で右大腿部術創が離開し たが保存的に軽快した。現在術後 8 ケ月を経て再発あるいは胸部創への感染兆候無く外来通院経過観察中であ る。大腿笳膜を用いた胸壁再建の実際について手術動画を用いて供覧する。 


\section{V3-3}

\section{導入化学放射線療法後に広範胸壁合併切除を伴う右上葉切除術}

○宮島 正博、高橋 有毅、鶴田 航大、植 龍之輔、多田 周、三品 泰二郎、渡辺 敦 札幌医科大学 呼吸器外科

【背景】高い線量の放射線照射は局所効果には優れるものの、組織の肥厚や凂着が起きるため、血管の剥離や系 統的なリンパ節郭清が困難になることが多く注意が必要である。今回、導入療法後手術を行った胸壁合併切除 を伴う右上葉切除術を経験したのでビデオを供覧する。【症例】71歳、男性。右側胸背部痛を主訴に来院。CT で右上葉に長径 $80 \mathrm{~mm}$ で第 $3 ， 4 ， 5 ， 6$ 肋骨に浸潤を伴う腫瘤影を指摘され、気管支鏡検查で肺扁平上皮癌の 診断となった。右肺癌 c-T3N1M0 c-stage3A で、まず放射線化学療法を施行した。CDDP+S1 を3 コース、肺 野、肺門部照射 60Gyにより腫癔、リンパ節の縮小を認め、手術治療目的に当科紹介となった。手術】第 7 肋間前腋窝線にポートを作成、胸胿内を観察、上葉と胸壁、縦隔に広範な瘾着を認めた。第 5 肋間に $13 \mathrm{~cm}$ の皮切を置き開胸、まず肺門部処理を行った。葉間、A2、V1-3、A1+3 の順に処理を進め、気管支を切断。胸 壁は第 3 肋骨から第 6 肋骨まで浸潤が疑われ胸望内より margin を確認、胁骨を切断した。上葉と胸壁を一塊 とし摘出し迅速診断で胸壁断端の陰性を確認した。その後に縱隔リンパ節を郭清した。さらに、傍心膜脂肪組 織による気管支断端被覆を施行した。最後に、胸壁欠損部をGoreTex patch を用い再建した。手術時間 5 時間 25 分、出血 $800 \mathrm{ml}$ 。病理結果は Ef3，yp-TONOM0 であった。術後経過に特に問題を認めず術後 19 日目に自宅 退院した。[考察]導入療法後の胸壁合併切除を伴う肺切除は、胸垫内瘉着や肺内の繊維化により難易度が増す が、胸脉鏡の併用やエナジーデバイスを適宜使用するなどの工夫により、安全に手術を行うことができた。 


\section{V3-4}

\section{右上葉 SSTに対 し、術前化学放射線 療法後Trans- manubrial approach にて右鎖骨下動眽合併切除を施行した 1 例}

○市川 智博、青景 圭樹、上田 琢也、勝又 信哉、沖 智成、大森 智一、仲宗根 尚子、後藤 真輝、 関原 圭吾、三好 智裕、菱田 智之、坪井 正博

国立がん研究センタ一東病院

症例は 61 歳男性。右肩峰痛、末梢の痺れを主訴に精查され右肺尖部腫瘤を認めた。右上葉腺癌 cT4(鎖骨下 動脈浸潤) N0M0 stage IIIA の診断にて、術前導入化学放射線療法として、CDDP+TS-1，66Gy を施行した。 腫瘍は長径 $4 \mathrm{~cm}$ から $2 \mathrm{~cm}$ まで縮小を認めたが、画像上右鎖骨下動脈浸潤は残存していた。手術は、Transmanubrial approach で開始した。上大静脈から右腕頭静脈・総頸静脈・鎖骨下静脈をテーピングし、鎖骨下動 脈の中枢及び末梢を確保した。静脈の 3 点合流部は腫瘍に背側から圧排されていたが、剥離可能であった。椎 骨動脈を結紮切離し、鎖骨下動脈を切除、8mm リング付き人工血管で再建した。腕神経叢から腫瘍瘷痕を剥離 し、前方からのアプローチで第 1 肋骨および第 2 肋骨を椎体から横突起を含めて合併切除し、胸腔内に落とし 込んだ。前方を閉創し、左側臥位に体位変換して後側方第 4 肋間開胸で上葉切除、リンパ節郭清を施行し、手 術終了した。手術時間は 567 分、出血は $1161 \mathrm{~g}$ であった。病理診断は右上葉肺腺癌 ypT4N0M0 stage IIIA, Ef 2 であり、完全切除を得た。術後経過は問題なく自宅退院し、現在外来経過観察中である。 


\section{V3-5}

\section{右 wedge 上葉切除を施行するも結果的に内腔の変形が全くみ られなかた手術}

$\bigcirc$ 奥村 栄、加藤 大喜、園田 智明、水室 直哉、平田 佳史、野間 大督、一瀬 淳二、松浦 陽介、 中尾 将之、文 敏景、中川 健 がん研究会有明病院呼吸器センター 外科

症例は、44 歳・男性。右上葉末梢（S2）のブラに隣接した最大径 $45 \mathrm{~mm}$ の肺腺癌で臨床病期は T2aN0M0$1 \mathrm{~B}$ であった。手術は、第 5 肋間開胸の後側方切開 (胸腙内観察後)。上葉気管支背側に腫瘍が近接しており、 通常の気管支切離は不可と判断して、上縦隔の郭清後に右 wedge 上葉切除を施行した。上幹頭側と中間幹側の 切離部を決定して wedge 切除を施行したが、膜様部でやや未梢側が長めとなる切離になってしまった。吻合 は、気管支軟骨の最媣部からの糸かけ (4-0PDS) を行い、順次結紮を施行。通常は中枢側の気管支軟骨が末梢 の膜様部に 1 針だけ縫合となっているが、末梢側の膜様部が長めになっていたこともあり、中枢側の気管支と 末梢の膜様部の吻合が 4 針となった。念のため、心膜脂肪織で吻合部の前壁を被覆した。術後 6 日目の気管支 鏡検查では、wedge 切除の場合に通常確認される分岐部側の変形 (たぐれこみ) が全くなかった。吻合部を確 認するとらせん状に吻合されていた。若年で気管支軟骨が柔らかいこととこのらせん状の吻合にて結果的に内 腔の変形を全くおこさなかった推察している。 


\section{V3-6}

\section{第 1 助軟骨胸骨付着部および左腕頭静脈に浸潤した左上葉肺癌 に対する前方アプローチ}

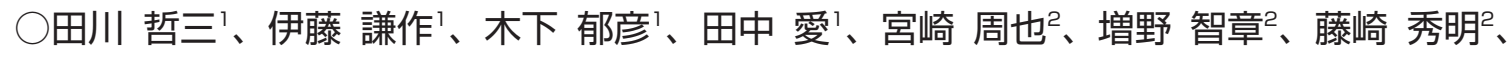
重永 武彦? 、本廣 昭

'大分赤十字病院 呼吸器外科、 ${ }^{2}$ 大分赤十字病院 呼吸器内科

【背景】前方胸壁に浸潤する肺尖部胸壁浸潤癌はアプローチ法の選択が難しい。第 1 肋軟骨胸骨付着部は transmanubrial approach (TMA) における切除部位であるが、同部に浸潤した肺癌に対してのアプローチ法を供覧 する。【症例】 68 歳男性、体重減少を主訴に近医を受診し、左肺上葉に $60 \mathrm{~mm}$ の充実性腫瘤を認め、左第 1 肋軟骨胸骨付着部から第 2 肋軟骨、左内胸動脈、縦隔脂肪織への浸潤を認めた。扁平上皮癌 (cT4N0M0, cStageIIIA）の診断により導入放射線化学療法（CDDP+S-1、RT 40Gy）を施行し、28\%の縮小（SD）を認め手術と なった。手術】仰臥位にて左鎖骨上から胸部正中へ皮膚切開し、胸骨を胸骨切痕から左第 2 肋間へ L 字型に切 開した。左第 2 肋骨を腫瘍浸潤部の遠位で切離し、左第 1 肋骨、胁軟骨上縁にて鎖骨下筋、肋鎖䩲帯を切離、 胸鎖関節を温存しながら胸骨左半側を第 1 肋軟骨胸骨付着部で横切し、最後に第 1 胁骨を鎖骨下静脈より正中 で切離して骨性胸郭 (胸骨左半側、左第 1,2 肋軟骨, 肋骨) を合併切除した。左腕頭静脈は腫瘍浸潤を認め合 併切除した。その後、皮膚切開㧍よび胸骨正中切開を第 4 肋間まで延長し、左第 4 肋間開胸を追加して hemiclamshell 型の approach とし、左肺上葉切除術を行った。胸骨は胸鎖関節部と第 2 肋間以下をワイヤーにて閉

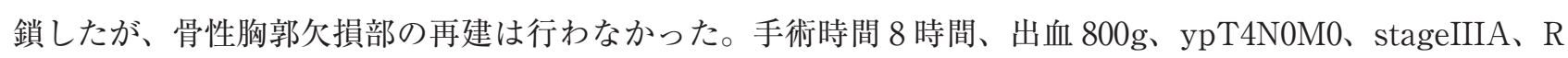
0、Ef1bであった。術後は喀痰貯留に対してミニトラックを挿入したが、経過良好で術後 20 日で療養転院と なった。【結論】胸鎖関節を温存しながら左第 1 肋軟骨胸骨付着部および左腕頭静脈を合併切除し、左肺上葉切 除術を完遂した。 


\section{V4- 1}

\section{CA 19-9 が高値を示し、アスペルギルスの不顕性感染を認めた CPAM の切除例}

○喜納 五月1、長阪 智1、酒井 絵美?、有本 斉仁?、横手 芙美?、松原 寛知 ${ }^{2}$ '国立国際医療研究センター 呼吸器外科、 ${ }^{2} 山$ 梨大学医学部付属病院 第二外科

症例は 40 歳代女性。 20 年前から左肺囊状気管支拡張症との診断。 1 年前に腹水が出現し、精査にて腹膜癌の 診断。腹膜癌に対し、前医で手術施行。腹水、腹膜播種病変を認め、两側卵巣切除+子宮全摘十播種性病変切除、 大網切除術を施行。術後化学療法 TC 3 コース施行。術前高值だったCA125 は正常化したが、CA19-9 がさ らに上昇した。PET CT で明らかな再発・転移は指摘できなかった。その後 TC+Bevを行ったが、CA19-9 は $1128 \mathrm{U} / \mathrm{ml}$ まで上昇した。原因検索として消化管検索 GS, CS 行ったが、異常所見はなかった。化学療法中 に左肺囊胞が感染し、抗生剂治療を行った。左肺囊胞感染の治療は 8 年前にも行っていた。今回繰り返すブラ (CPAM) 内感染のコントロール目的に手術を施行した。造影剂アレルギーがあるため、術前画像検査は単純 CT のみであった。手術は胸腔鏡下でアプローチ。術中切除区域肺から膿汁が流出。囊胞周囲の癒着剥離にや や難渋したが、完全胸腔鏡下に左 S1+2 区域切除術を施行した。術後 CA19-9 は急速に正常域に戻ったが、術 中の膿汁培養からアスペルギルスが検出され、ITCZ の内服治療を開始した。病理組織診断は CPAM1 型 (CCAM I 型)であった。腹膜癌術後の化学療法中にCA19-9 が上昇し、アスペルギルスの不顕性感染を認めた $\mathrm{CPAM}$ の 1 例を経験した。霊胞性肺疾患では気道上皮由来の腫瘍マーカーが非特異的に、悪性疾患と鑑別を要 する程の高值をとり得ることを念頭において診断を進めることが必要であると考えられた。 


\section{V4-2}

\section{肺結核術後の肺アスペルギルス症による致死的喀血に対して残 存肺全摘を施行し救命した 1 例}

$\bigcirc$ 藤永 卓司、池田 政樹、萩原 清彦、村田 祥武

国立病院機構長良医療セン夕一 呼吸器外科

肺アスペルギルス症は時に致死的な気道内出血を起こしうる。今回我々は大喀血により人工呼吸管理となっ た症例に左肺全摘術を施行し、救命し得た症例を経験したので報告する。症例は 65 歳女性、44 歳の時に多剤 而性肺結核にて左上葉切除術を施行、その後肺 MAC 症、肺アスペルギルス症を合併し、当院呼吸器内科に通 院していた。時々血痰を認めるも止血剤にて経過していたが、 $201 X$ 年 11 月コップ半分程度の喀血があり、入 院となった。入院後に大量喀血し、気管内挿管、人工呼吸管理となった。フォガティーカテーテルで左主気管 支からの出血をブロックしつつ気管支動脈塞栓術が施行された。2 日後出血なく、抜管となるも間もなく、咳 嗽とともに大量喀血し窒息、再抻管となった。再度気管支動脈塞栓術を行うも左主気管支からの血液の流出が 止まらず、手術目的で当科紹介となった。手術所見：右側臥位、皮膚切開は後側方切開で前鋸筋と広背筋は有 茎筋弁として温存した。第 $4,5,9$ 肋骨を切除し胸腔内に至ったが、全面に強固な瘉着を認めた。心囊内で血 管処理を行い、広範囲心膜とともに左残肺全摘を施行した。最初に準備した筋弁を用いて気管支断端被覆と死 腔閉鎖を行い、胸郭成形を追加して手術を終了した。手術時間は 9 時間 20 分、出血量は $3100 \mathrm{ml}$ であった。術 中摘出した菌塊からは Asp.fumigatus と Steno.maltophilia が検出された。術後抗生剂投与とともにファンギゾ ンによる胸腔洗浄を行った。術後 69 日目に独歩退院となった。現在、再燃なく経過している。術中ビデオを供 覧する。 


\section{V4-3}

\section{結核性左主気管支狭窄、左上葉荒茬肺に対し左上葉管状切除・ 再建を施行した 1 例}

○村 通孝、高濱 誠、中嶋 隆、水口 真二郎、井上 英俊、大橋 拓矢、山本 良二 大阪市立総合医療セン夕ー 呼吸器外科

【はじめに】肺結核においては、治療後も気道変形・狭窄を来し、無気肺、荒黄肺を形成することがある。今回 抗結核薬治療後 7 年経過して左主気管支狭窄および左上葉荒黄肺を呈した症例に対し、左開胸による左上葉管 状切除、気道再建を行った症例を経験したのでビデオを供覧する。【症例】 49 歳、男性。42 歳時に肺結核治療 歴あり。数年前より咳嗽を認めており、喘鳴、呼吸困難が増強するため近医受診。胸部 CT で左上葉の荒囬肺、 左主気管支の狭窄が認められ、結核性気管支狭窄症と診断した。気管支鏡検查では左主気管支は入口部から狭 小化を認めており、上葉枝は入口部から閉塞していたが、下葉枝は開存していた。【手術】左後側方切開第 4 肋間開胸でアプローチ。まず左上葉荒黄肺を上葉気管支レベルで切離し摘出。左主気管支をテーピングし、気 管分岐部まで剥離を行い、さらに気管をテーピング、剥離を行い受動した。左主気管支の変形、狭窄部位を確 認し、上下葉枝分岐部を含めた約 $3.5 \mathrm{~cm}$ 長の最狭窄部を切除。中枢側の狭小気管支壁を拡張するよう下葉枝と 口径を合わせ、5-OPDSII で結節縫合による端々吻合、再建を行った。手術時間 5 時間 58 分、出血量 $130 \mathrm{ml}$ 【経過】術後喘鳴、呼吸困難の自覚症状は消失し、気管支鏡検査では吻合部狭窄なく、中枢側の狭窄も引き延ば されるように気道が確保されていた。 


\title{
V4-4
}

\section{胸囲結核に対する 1 手術症例}

\author{
○鍵本 篤志、柴田 諭
}

独立行政法人国立病院機構東広島医療セン夕一＼cjkstart呼吸器外科

【症例】 76 歳男性【現病歴】大腸癌に対する術前検查目的にCT を撮影したところ、右胸壁から肝臟にかけて 腫瘤を認めた。CT ガイド下に穿刺を行ったところ排膿があり、抗酸菌培養検査で結核菌が同定されたため胸 囲結核と診断された。大腸癌に対する手術を施行した後にINH+RFP+EB+PZA による治療を開始したが、膿 瘍増大傾向であったため外科的加療に関して当科紹介受診となった。【既往歴】 50 年前に肋骨カリエスにて手 術歴あり。【手術】皮下組織を剥離し膿瘍の表面を覆う前鋸筋を通して $12 \mathrm{Fr}$.のアスピレーションキットを挿入 した。膿瘍内から排膿・洗浄した後に切除のメルクマールとするためにインジゴ色素を注入した。膿瘍は肋間 筋を貫きダンベル状に胸腔内へ達していたため、第 7、8、9 肋骨を部分的に切除した。胸腔内では肺との癒着 を認めたためこれを剥離した。また、横隔膜を貫通していたため合併切除し、肝臓と膿瘍間の線維性癒着を剥 離し膿瘍を摘出した。横隔膜の欠損部を縫合閉鎖し、広背筋で胸壁を再建し手術を終了した。【考察】胸囲結核 では手術の有無に関わらず肺結核に準じた内服加療を行うが、本症例のように抗結核薬の内服加療を 3 力月 行っても反応性が無い場合や胸腔内病変を認める場合は外科的加療を考慮するべきとされている。また、胸壁 内を不規則に膿瘍が広がっている場合があり、再発を予防するためにも完全切除する必要がある。本症例では 完全切除を得るためにインジゴにて切除範囲を明確にする工夫を行った。結語】外科的治療を行った胸囲結核 の 1 例を経験した。内科的治療に抵抗性であった場合は、完全切除を目指した外科治療を考慮する。 


\section{V4-5}

\section{部分切除または stapling のみによる区域間切離が困難な巨大 良性囊胞性腫瘤に対する左 S10 区域切除}

$\bigcirc$ 藤原 俊哉、中村 龍二、荒木 恒太、岡田 真典、西川 仁士、松浦 求樹 広島市立広島市民病院＼cjkstart呼吸器外科

【緒言】近年，末梢性小型肺癌に対して積極的に区域切除が行われ、肺癌診療ガイドラインでも区域切除を行う ことを考慮してもよい (グレード C1) とされている. 区域切除は呼吸器外科医にとって、普遍的に行い得なけ ればならない術式と考えてよい。ただし、切除区域によって難易度は異なり, 底区域領域は比較的困難な領域 であると考える. その理由として, 肺底静脈の variation が多く同定しづらいこと, それに伴い肺動脈や気管支 の同定に肺静脈を指標にしづらいことが挙げられる，良性疾患については、より肺を温存することが肝要であ り、肺温存術式が要求される. 今回, $10 \mathrm{~cm}$ を超える巨大な囊胞性腫瘤に対して左 S 10 切除を行った. 【症例】 44 歳, 女性．契煙歴なし．6か月前より、左胸痛を自覚するようになった。4 か月前、健診を受診した際に、 左下肺の異常陰影を指摘された。2 か月前、当院を受診し、CT にて左下葉に巨大な囊胞性腫瘤を指摘された。 PET では有意な FDG 集積を認めなかった，肺分画症などの良性疾患を疑い，造影 CT を行ったが、明らかな 異常血管は描出されなかった。肺囊胞性疾患として手術の方針とした. 聴診三角に $4 \mathrm{~cm}$ の小切開をおき、ハイ ブリッドVATSによる左S10 区域切除を行った。病理では肉芽腫であり、抗酸菌検査で M.avium を検出し た。【考察】腫瘍を取り残すことなく、切除するには部分切除あるいは区域間を stapling のみで切離するのは不 可能であると考えられたため、肺癌に対するリンパ流郭清を念頭においた区域切除手技に倣って、S10区域切 除を施行した。手術手技を供覧する。【結語】巨大な䨝胞性腫㢚に対して解剖学的左 S10 切除を行った. 


\section{V4-6}

\section{臓器移植後に発症した肺膿瘍に対してドレナージ術を施行した 2 例}

○山本 陽子、新谷 康、谷口 聖治、久能 英法、神崎 隆、川村 知裕、舟木 壮一郎、南 正人、 奥村 明之進

大阪大学大学院医学系研究科 呼吸器外科

【背景】臓器移植後の免疫抑制治療は、移植臓器の拒絶反応を抑制するためには必須の治療である。一方で易感 染性から重篤な呼吸器感染症を発症しうる。今回、当院で臟器移植後に発症した肺膿瘍に対してドレナージ術 を施行した 2 例を経験したので報告する。【症例 1】56 歳男性。1 型糖尿病、糖尿病性腎症にて脳死膵腎同時移 植術施行された。術後 5 年目に左重症肺炎を発症し、抗菌薬治療が開始されたが肺炎随伴性胸水貯留を認め胸 腔ドレナージを行った。胸腔ドレーンょりエアーリーク出現し CT にて左下葉に空洞性病変を認めた。肺膿 瘍、肺膿瘍穿破による膿胸と診断し緊急手術の方針とした。【症例 2】63 歳男性。B 型劇症肝炎にて脳死分割肝 移植施行された。術後 1 力月目に左肺に空洞性病変を認め、血性痰および対側肺に浸潤影が出現した。肺膿瘍 および肺胞出血？同病変からの出血？と考え緊急手術の方針とした。手術及び術後経過】開胸時いずれの症例 でも膿瘍部と胸壁に癒着を認めなかった。肺膿瘍周囲臓側胸膜に巾着縫合をかけ、同部位に $24 \mathrm{Fr}$ トロッカーカ テーテルを挿入した。さらに周辺の肺実質と胸壁を固定し、トロッカーカテーテルが胸壁から最短で膿瘍腔へ 達するように外瘻化した。胸水・肺膿瘍の培養結果は陰性であった。術後ドレナージと抗菌薬加療を継続し呼 吸状態と炎症反応の改善を認め、術後 2 ヶ月目にトロッカーカテーテルを細径化した上で抜去し、2例とも再 燃を認めなかった。【とめ】臓器移植後、免疫抑制剂内服中に発症した肺膿瘍に対して膿瘍腔を外瘻化するこ とにより治癒した 2 例を経験した。ステロイド治療などにより胸腔内の癒着がなく、外瘻化には工夫が必要で ある。 


\section{V5- 1}

\section{気管支楔状切除 (deep wedge 法) を用いて右上葉の温存が可 能であった肺癌の一例}

○富岡 泰章、戸矢崎 利也、上田 雄一郎、後藤 正司、中川 達雄 天理よろづ相談所病院 呼吸器外科

【はじめに】肺癌手術に際し、病巣が中枢に及ぶ場合は呼吸機能を温存する目的で気管支形成術が考慮される。 管状切除術はより確実な切離マージンが確保できるが、気管支を完全に離断するため吻合部の阻血が懸念され る。一方、 deep wedge 法は気管支の連続性が保たれるため、吻合部血流が維持されると共に、吻合面も合わせ やすく、手技的にはより簡便である。今回 2nd carina 近傍に浸潤した肺癌に対し deeep wedge 法を用いて右上 葉の温存が可能であった一例を経験したので報告する。【症例】 82 歳、男性。咳嗽・血痰を主訴に近医を受診。 CT で右中間気管支幹から下幹を閉塞する腫瘍を認め当院に紹介となった。CT で右中間気管支幹から下幹起 始部を閉塞する約 $5 \mathrm{~cm}$ の分葉状腫瘤を認めた。気管支鏡では中間気管支幹を閉塞する隆起性病変を認め、2nd carina 近傍の粘膜が発赤し浸潤が疑われた $(\mathrm{cT} 2 \mathrm{aN} 1 \mathrm{M} 0)$ 。手術は第 4 肋間前方腋窩開胸で右中下葉切除（R2 b)を行った。気管支の切離は、 deep wedge に切り込み、内腔を確認しながら 2nd carina から距離をとるよう に上葉気管支へ切り込み、これと合わさる主気管支側はやや長め残し吻合しやすくした。術中迅速病理検査で 切離断端は陰性であり、4-0 吸収糸モノフィラメントで最深部より 2 方向から連続縫合を行い、合流部で結紮 した。吻合部は遊離心膜脂肪織で被覆した。術後気管支鏡所見では、吻合部の狭窄はなく粘膜色調は良好であっ た。deep wedge 法は気管支の創傷治癒の面、吻合が比較的容易であることから有用な術式であると考えられ る。これまで当院において行った deep wedge 法による気管支形成術 8 症例に関しても合わせて報告する。 


\section{V5-2}

\section{根治的放射線化学療法後に施行した ycT4 (椎骨) NO 肺癌に対 する左肺上葉切除術＋椎骨合併切除術}

○吉田 周平、松本 勲、古山 和憲、田中 雄亮、齋藤 大輔、懸川 誠一、田村 昌也、竹村 博文 金沢大学 先進総合外科

【はじめに】椎骨浸潤を伴う肺癌に対しては, 集学的治療により完全切除が可能であれば予後の改善が期待でき る.【症例】 47 歳, 男性. 左背部痛を主訴に紹介医受診. 左肺上葉に約 $4 \mathrm{~cm}$ の腫瘤あり, 第 2 胸椎および第 2 ・ 3 肋骨に浸潤がみられ cT4 (椎骨) N2M0 左上葉肺癌（NSCLC）と診断された。前医にて根治的放射線化学療 法として weekly CBDCA（AUC2)+PTX (40mg/m2) および同時放射線療法（66Gy）施行し，その後地固め として CBDCA (AUC4) +PTX $(60 \mathrm{mg} / \mathrm{m} 2)$ を2 コース施行. 原発巣および縦隔リンパ節の縮小が得られ (ycT 4NOM0), サルベージ手術としての完全切除が可能と判断され手術目的に当科紹介, 椎骨合併切除を伴う左肺 上葉切除術の方針とした。【術中所見】右側臥位とし後側方 $20 \mathrm{~cm}$ の皮虐切開をおき第 4 肋間開胸. 腫瘍は S1 +2 に存在し第 2 胸椎浸潤あり. まず大動脈弓より頭側で左肺上葉の腫瘍部を胸壁側に残す形で部分切除. 左肺 上葉切除を施行し, 横隔神経, 迷走神経, 肺動脈本幹にテーピングを行い動脈管索を切離したうえでリンパ節 郭清（ND2a-1）施行．その後胸腔内から腫瘍より十分に margin をとり第 2,3 胁骨を切断. 第 2 椎骨腹側の 剥離が必要と整形外科が判断し，やむなく第 2 椎骨より残存肺を離断した．その後腹臥位とし第 2 胸椎骨，第 $2 \cdot 3$ 肋骨を摘出し手術終了. 手術時間 11 時間 31 分, 出血量 $510 \mathrm{~g}$.【術後経過】術後第 3 病日に経口摂取開始, 第 9 日病日に歩行開始. 特に合併症は認めず, 第 35 病日に独歩退院した. 術後病理所見では肺および椎骨に残 存腫瘍細胞なし（ypT0N0M0, Ef.3）。現在術後 8 力月, 無再発生存中である. 術中動画を供覧する. 


\section{V5-3}

\section{第 1 助骨浸潤を伴う superior sulcus tumor の 1 切除例}

○野間 大督、松浦 陽介、加藤 大喜、園田 大、永室 直哉、平田 佳史、一瀬 淳二、中尾 将之、 文 敏景、中川 健、奥村 栄

がん研有明病院 呼吸器外科

【緒言】第 1 肋骨は鎖骨下動静脈、腕神経叢等の重要臟器に接し、その切除には胸郭入口部の正確な解剖学的知 識と良好な手術視野が必要となる。一方、第一肋骨切除を伴う胸壁合併切除を経験する機会は少ないため、実 際の手術で得られた知見を共有することは重要と考える。【症例】 66 歳男性。右胸痛を主訴に前医を受診。精 查の結果、右肺尖部に最大径 $82 \mathrm{~mm}$ の腫瘤を認め、当院へ紹介となった。腫瘍は第 1,2 肋骨背側へ浸潤を認 め、気管支鏡検査にて Sq, cT3N1M0, IIIA と診断した。術前導入化学放射線療法 CDDP+S-1+RTx 40Gy 実施後、第 1,2 横突起合併切除を伴う第 1-3 肋骨 +右上葉切除, ND2a-1 を施行した。術後病理診断は ypT 1aN0M0，IA，Ef2 の判定であった。【胸壁切除】1)開胸法と視野展開：背側の皮膚切開を第 1 棘突起レベルま でためらわず切り上げ後側方開胸をおき、肩甲骨をケント鈎で鈞り上げることで胸郭入口部構造物のうち外側 から確認が必要な後斜角筋、中斜角筋、鎖骨下動静脈に非常に良好な視野でアプローチ可能で、最上肋間動脈 も安全に処理できた。2)横突起の処理 : 脊柱起立筋を椎体より十分剥離することで、骨ノミを垂直にあてがう ことが可能となった。また、胸腔鏡を併用し肋横関節離断ラインを胸腔側より確認した。3) 第 1 肋骨切除 : 胸 腔内からの操作が必要で、特に腹側の視野は不良で操作野の確保が困難である。胸腔鏡を併用し、前斜角筋切 離後に胁骨腹側を確保した後、線鋸を用いて切離した。背側では椎体切離後に交感神経星状神経節、第 1 胸神 経を結紮切離した。【結語】視野の展開と第 1 肋骨の処理を中心とした手技を供覧する。 


\title{
V5-4
}

\section{体外循環補助下の局所進行非小細胞肺癌の肺切除経験}

\author{
渡辺 光、渡辺 勇、金内 直樹 \\ 日本海総合病院 呼吸器外科
}

【はじめに】臨床病期 T4 非小細胞肺癌の外科切除は合併切除臟器により差はあるが、致命的合併症の頻度が高 く、慎重な患者選択が必要である。しかし、完全切除のより長期生存の可能性があり、どこまで治療選択の幅 を広げるかについては議論の余地がある。特に完全切除目的に体外循環を利用した肺切除を行うことに関して は、現在コンセンサスを得られていない。【症例】55 歳の男性。胸痛、呼吸困難感を主訴に救急外来を受診し、 $\mathrm{CT}$ 検查で右肺門に最大径 $70 \mathrm{~mm}$ の腫瘤を認めた。腫瘤は肺静脈内を進展し、左房内に突出する形態を示して いた。気管支鏡検查で扁平上皮癌と診断であった。経胸壁心臓超音波検査で左房内腫瘍は可動性良好であり、 腫瘍塞栓および血行動態の破綻に伴う突然死のリスクが懸念された。体外循環を使用することで致命的合併症 や原疾患の増悪の危険性も考慮されたが、腫瘍切除の有益性が危険性を上回ると判断し、手術の方針とした。 手術は体外循環補助下に左房合併切除を伴う右肺全摘術を施行した。術後は塞栓症などの合併症もなく、術後 10 日で退院した。【結語】担癌患者における体外循環使用については、癌細胞の播種や免疫系への関与による 原病増悪の可能性も懸念され、適否については議論が残るところである。全身状態が良好で一定の予後が期待 できれば、手術の危険性と治療の有益性を慎重に検討したうえで、体外循環下の肺切除を考慮することも許さ れると考えられる。当院での体外循環補助に伴う使用経験 2 例に加え、若干の文献的考察を加えて報告する。 


\title{
V6-1
}

\section{肺癌術後異時性肺転移に対する 5 回の肺転移巣切除術}

\section{Five sequential resections of pulmonary metasta- ses from lung cancer.}

\author{
清水 公裕、永島 宗晃、大瀧 容一、尾林 海、中澤 世識、東 陽子、飯島 岬、高坂 貴行、 \\ 矢島 俊樹、茂木 晃、桑野 博行 \\ 群馬大学医学部附属病院外科診療センター 呼吸器外科 \\ OKimihiro Shimizu, Toshiteru Nagashimz, Youich Ohtaki, Kai Obayashi, \\ Seshiru Nakazawa, Youko Azuma, Misaki lijima, Takayuki Kousaka, Toshiki Yajima, \\ Akira Mogi, Hiroyuki Kuwano \\ Division of General Thoracic Surgery, Integrative Center of General Surgery, \\ Gunma University Hospital, Gunma, Japan
}

第三世代 EGFR-TKI の登場により、EGFR-TKI 治療後の再発病変に対する re-biopsy の必要性も高まり、 今後より再発病巣に対する手術機会が増える事が予測される。しかし、再発病変の部位が、特に術側の胸腔内 にある場合は、強固な癒着などにより剥離操作が難しい症例も多い。さらに、再発病変では、初回手術で肺葉 切除以上が行われている症例が多く、残存肺機能を勘案した術式の検討も必要になる。我々はこれまでに、肺 腺癌術後再発に対する gefitinib 治療後に再燃した、孤立性肺転移に対して、計 5 回の肺切除により局所制御を 行いない gefitinib の投与を続け、再発後約 9 年間の病勢制御を得ている症例を経験している。症例は 62 歳女 性。右肺上葉肺癌に対して右肺上葉切除＋右 S10 部分切除を施行した。術後 1 年 7 ケ月で多発肺転移再発を認 め、EGFR 変異陽性であったため gefitinib を導入した。まず、導入直後に発生した肺肉芽腫に対して右肺 S910 部分切除を行い、その後、肺転移に対して、術後約 5 年目に左 S10 区域切除、術後約 7 年目に右 S8 部分切 除、術後約 8 年目に右 $\mathrm{S} 6+9+10$ 区域切除、術後約 9 年目に左残存 S6 区域切除術を施行した。特に、右 S6 $+9+10$ 区域切除は、複数回の部分切除を行った下葉に対する複雑区域切除であり、さらに左 S6 区域切除に関 しては、同一肺葉内の S10 区域切除後の再区域切除であるため、伴に難易度の高い手術であった。そこで今回 我々は、本症例のビデオを供覧し、再発症例に対する手術の難しさと、再手術における区域切除のコツについ て述べるとともに再発肺癌に対する手術の意義について議論したい。

\section{Abstract}

Significance of re-biopsy for pulmonary metastasis (PM) from EGFR mutation positive lung cancer is increasing due to introduction of 3rd generation EGFR-TKIs. However, resection of PM is a technical challenge when located ipsilaterally to prior surgeries. The patient we present here underwent five pulmonary resections for sequential PMs of lung cancer. The case was a 62-year-old female with primary lung cancer who underwent right upper lobectomy with right S10 wedge resection. Pathological and genomic examinations re- 
vealed that the tumor was an EGFR mutation-positive adenocarcinoma ( $\mathrm{p}^{-}$-stage IB). At 1 year and 7 months postoperatively, bilateral multiple PMs were found, and administration of gefitinib was started. The bilateral PMs decreased dramatically in size, except for the right S10 tumor. Thus, we performed right S10 wedge resection. Pathological examination revealed that the tumor was a caseating granuloma. Therefore, gefitinib treatment was continued, and a complete response was attained. At 5 years after initial surgery, the three PMs in the left S10 increased in size. We performed left S10 segmentectomy. At 7 years after initial surgery, an additional PM was detected in the right S10. We performed right S10 wedge resection. At 8 years after initial surgery, a PM was detected in the right S6. We performed right S6+S9+S10 segmentectomy. At 9 years after initial surgery, a PM was also detected in the left S6. We performed left S6 segmentectomy, which was technically difficult because it was located in the same lobe as the prior left S10 segmentectomy. At the present time, her quality-of-life and pulmonary function are well-maintained. In this session, we would like to present videos of right $\mathrm{S} 6+\mathrm{S} 9+\mathrm{S} 10$ and left $\mathrm{S} 6$ segmentectomies and discuss about significance of repeated resections for PMs. 


\section{V6-2}

\section{当院における再発肺癌に対する手術}

\section{Surgical treatment for postoperative recurrent pulmonary tumor}

○石橋 洋則、川田 悠、杉田 裕介、栗原 泰幸、宇井了子、熊澤 紗智子、高崎 千尋、小林 正嗣、 大久保 憲一

東京医科歯科大学 呼吸器外科

OHironori Ishibashi, Yuu Kawada, Yasuyuke Sugita, Yasuyuki Kurihara, Akiko Ui, Sachiko Kumazawa, Chihiro Takasaki, Masashi Kobayashi, Kenichi Okubo

Department of Thoracic Surgery, Tokyo Medical and Dental University, Japan

肺癌治療成績の向上により、肺癌術後肺腫瘍手術は増加している。再手術、年齢・心肺機能などから治療法 の選択に苦慮する場合も多い。当施設で 2010 年 4 月から 2016 年 11 月に施行した原発性肺癌は 891 例、うち初 回標準手術後肺腫瘍再発に対する再手術は 44 例 $(4.9 \%)$ 。術同側の手術は 23 例。再手術術式は部分切除 10 例、区域切除 9 例、葉切除 2 例 (中葉切除後の中下葉切除 1 例 - 右上葉切除後中葉切除 1 例)、残肺全摘 2 例。 部分切除による病巣摘出不能症例では残肺全摘となることが多いが、肺全摘回避には区域切除など術式に工夫 が必要である。手術ビデオはサルベージ左上葉切除後再発性肺癌に対する左 S6+S10 区域切除術を提示する。 症例は 82 歳、男性。既往歴は高血圧、糖尿病。契煙歴は 10 本 50 年間の current smoker、PS1。76 歳時、左上 葉原発性肺腺癌 cT2aN2M0 に対し、化学療法施行後、当院で開胸左上葉切除+ND2a-2 施行。胸腔内全面癒着 があり肺門リンパ節が肺動脈に浸潤し遮断の上、剥離摘出。術後病理検査は ypT3N2。8 歳時 CT で左下葉に 大動脈に接する長径 $45 \mathrm{~mm} 、$ PETCT で高集積（SUVMax20）の腫瘍指摘。術前呼吸機能検査は VC2190ml (77.6\%)、FEV1.0 1360ml (61.2\%)、DLCO 8.6mL/min/mmHg (75.0\%)。肺血流シンチで左 $11 \%$ 。診断・治療 目的に手術施行。胸腔内は非常に強固な全面癒着で後側方第 6 肋骨床開胸。PA の癒着は非常に強固で、中枢 側 PA 剥離テーピングは困難。 $\mathrm{V} 6 \cdot \mathrm{B} 6$ 処理後 $\mathrm{A} 6$ を結紮切離。 $\mathrm{V} 10 \cdot \mathrm{B} 10 \cdot \mathrm{A} 10$ の順に結紮切離。 B6/10 気管 支断端から肺をインフレートし境界にそって切離、腫瘍を摘出した。最終病理診断は再発性肺癌。術後合併症 なく 8 日目退院、現在外来通院中である。

\section{Abstract}

We retrospectively reviewed the medical records of 23 consecutive patients who had undergone repeated surgery for lung cancer at our institution between April 2010 and September 2016. Surgical treatment for the first tumors consisted of lobectomy in 18 patients and segmentectomy in 5 patients. The second tumors were removed by partial resection, segmentcctomy, lobectomy and completion pneumonectorny in 10, 9, 3 (one case of right lower lobectomy after middle lobectomy, and right middle lobectomy after upper lobectomy), and 2 
patient, respectively. We present a case of left S6/10 segmentectomy after salvage left upper lobectomy. 82year-old male patient received salvage left upper lobectomy after chemotherapy for pT2aN2M0 lung adenocarcinoma at 76 years of age. As hilar lymph nodes were firmly adherent to pulmonary artery, pulmonary artery was totally clamped and lymph nodes were excised. A follow-up chest computed tomography showed a 45-mm mass in the left lower lobe beside aorta (abnormal uptake SUV max 20 by Positron emission tomography). Cytological studies by bronchoscopy were negative. Pulmonary function tests were normal. With the clinical suspicion of recurrent lung cancer, S6/10 segmentectomy was planned. A left 6th intercostal thoracotomy revealed severe inflammatory pleural adhesions throughout the left thoracic cavity. Although the tumor was firmly adherent to aorta, the tumor was dissected from aorta. Pulmonary artery was firmly adherent to parenchymal lung and difficult to be dissected, A6 were dissected after dissection of V6 and B6. S10 and S6 segments were inflated by air blow and resected after dissection of V10, B10 and A10.The patient had an uneventful postoperative recovery and the tumor was diagnosed as recurrent lung cancer. 


\title{
V6-3
}

\section{右上葉切除後右下葉肺内転移に対する抗癌剮治療後のサルベー ジ右下葉切除術の一例}

\section{Salvage right lower lobectomy after right upper lobectomy followed by chemotherapy for T4 (pme) NOMO lung cancer}

\author{
○白橋 幸洋、岩田 尚、山本 裕崇、松本 光善、宮本 祐作、土井 潔 \\ 岐皁大学大学院医学系研究科 高度先進外科学分野 \\ OKoyo Shirahashi, Hisashi Iwata, Hirotaka Yamamoto, Mitsuyoshi Matsumoto, \\ Yusaku Miyamoto, Kiyoshi Doi \\ Department of General and Cardiothoracic Surgery, Graduate School of Medicine, Gifu University
}

症例は 60 歳代, 女性. 6 年前に右上葉肺癌 (adenocarcinoma) と右下葉に多発する未確診の小結節影を認め, 右上葉切除術, 右下葉部分切除術, 縦隔リンパ節サンプリング（\#4R）を施行した. 右下葉結節が肺内転移で あったため pT4N0M0 stage IIIA の診断となり, 術後約 6 年間化学療法を施行された. 右下葉の結節は緩徐に 増大傾向を示したが, 右中葉、左肺に院影を認めなかったため, 右下葉に対し手術する方針となった. 胸部 CT では右 S8 を中心にほほ右下葉全体を占拠する辺縁不整の consolidation を認め, 右中葉には病変を認めなかっ た. PET では腫瘍に一致して SUVmax 6.89 の集積を認めた。換気血流シンチで計算した肺全摘術での予測肺 機能は ppo\% VC=50.8\%, ppoFEV1.0=810ml と可能であった. まずは右下葉切除術を予定し, 葉間肺動脈の剥 離が困難であれば全摘の方針とした，後側方第 6 肋間で開胸した．癒着が高度であることと腫瘍を散布しない ようにするために後方より壁側胸膜外に癒着を剥離し, オリエンテーションが付いたところで胸膜内から下葉 周囲の癒着を剥離した. S6 付近で葉間が確認できたためこれを剥離し葉間肺動脈を露出した. 総肺底動脈を剥 離し stapler で切離し, A6 は前回の手術で炎症性の癒着はあるもののテーピングは可能で stapler で切離し た.下肺静脈、気管支周囲の剥離は可能で stapler で処理した. 横隔膜面の癒着が強く一部横隔膜を合併切除し た. \#7リンパ節を郭清し断端は心膜脂肪織で被覆し手術を終了とした. 術後経過は良好で術後 11 日目に退院 となった. 術後病理は invasive mucinous adenocarcinoma であり, 前回の手術と同様の組織で周囲への浸潤傾 向はなく完全切除された.

\section{Abstract}

A 65-year-old woman who underwent right upper lobectomy, partial resection of the right lower lobe, and mediastinal lymph node sampling for T4N0M0 pulmonary adenocarcinoma 6 years ago was referred to our department. Despite several postoperative chemotherapy sessions, follow-up CT revealed a gradually increasing metastatic nodule leading to consolidation in the right lower lobe, but not the apical segment or the 
posterior site. On PET, the tumor showed a SUV max of 6.89 in the consolidated area. There was no metastasis to the right middle lobe or left lung, and no extrathoracic metastatic lesions were identified. We planned complete right lower lobectomy to preserve her pulmonary function. Predicted postoperative \%vital capacity and forced expiratory volume in 1 second were $50 \%$ and $810 \mathrm{ml}$, respectively, after completion right pneumonectomy using ventilation-perfusion scintigraphy. Through a posterolateral incision in the right sixth intercostal space and after identification of the intrapleural space, we dissected adhesions around the right lower lobe to avoid tumor dissemination. After dissecting the interlobar space between the right lower and middle lobes, the basal artery was identified and cut using a stapler. Although adhesions existed around the apical artery of the right lower lobe, they could be safely dissected and cut using a stapler. The right lower vein and lower bronchus were also cut using a stapler. Since there were severe adhesions around the diaphragm, we performed partial resection of the diaphragm. The bronchial stump was covered with a pericardial fat pad and sub-carinal lymph nodes were dissected. Her postoperative course was uneventful and she was discharged on postoperative day 11. Postoperative pathological evaluation revealed invasive mucinous adenocarcinoma with no metastasis to the resected lymph nodes. Hence, complete resection was achieved. 


\title{
V6-4
}

\section{根治照射後に局所再発を来し救済手術を行った左上葉肺腺癌の 1 例}

\section{Salvage surgery for lung cancer recurrence after stereotactic body radiation therapy}

\author{
○関原 圭吾、青景 圭樹、上田 玩也、沖 智成、三好 智裕、菱田 智之、坪井 正博 \\ 国立がん研究センター東病院 呼吸器外科 \\ OKeigo Sekihara, Keiju Aokage, Takuya Ueda, Tomonari Oki, Tomohiro Miyoshi, \\ Tomoyuki Hishida, Masahiro Tsuboi \\ Division of Thoracic Surgery, National Cancer Center Hospital East, Chiba, Japan
}

\begin{abstract}
症例は 66 歳、男性。 40 本/日、 22 年間の喫煙あり、特記すべき既往歴なし。左上葉肺腺癌 cT1aN0M0 StageIA 0 に対して患者希望で根治照射 (60Gy/30fr) 施行した。 42 か月後に局所再発を来したため、救済手術を行う方 針となった。腫瘍は最大径 $47 \mathrm{~mm}$ 、縦隔と胸壁への浸潤が疑われた。手術は皮切 $15 \mathrm{~cm}$ 、後側方切開第 5 肋間開 胸でアプローチ、第 4 肋骨を後方で切離した。胸腔内は炎症性の全面癒着。腫瘍は胸壁と縦隔に強固に癒着し ていた。横隔神経も巻き込まれており浸潤が疑われた。まず、骨膜を露出する胸膜外の層で剥離した。横隔神 経を尾側で taping して、縦隔脂肪を margin に留意しながら腫瘍を受動していった。横隔神経を温存しながら 可動性を得ることが困難であったため、肺門の処理を先行する方針とした。血管の処理後、胸壁から腫瘍を剥 離していった。胸壁との癒着は非常に強固で内胸動脈を損傷したため clipping した。瘷痕化した縦隔組織を margin に十分留意しながら、腫瘍の頭側で横隔神経を taping した。慎重に剥離を進めて横隔神経を温存し、 左上葉切除を完遂した。手術時間は 236 分、出血は $243 \mathrm{~g}$ であった。術後経過には問題なく退院した。当院で救 済手術を行った症例の成績を含めて、若干の考察を加えて報告する。
\end{abstract}

\section{Abstract}

The patient was 66-year old male with no past serious illness and heavily smoking history of 44 pack-years. He hoped stereotactic body radiation therapy $(60 \mathrm{~Gy} / 30 \mathrm{fr})$ for a treatment of stage IA lung adenocarcinoma and radiotherapy was completed without a major adverse effect. However, primary lesion has been gradually enlarged to $5 \mathrm{~cm}$ mass on computed tomography after 42 months of radiotherapy. The lesion was pathologically diagnosed as an adenocarcinoma recurrence. Salvage surgery was planned and conducted. A $15 \mathrm{~cm}$ postlateral incision was made and the pleural cavity was entered through a fifth intercostal space. There was an inflammatory pleural adhesion in the whole thoracic cavity. The lung parenchyma was rigidly adhesive to the anterior chest wall and mediastinum. Phrenic nerve was also involved in the tight adhesion. Hilar approach was preceded by adhesiotomy because of a tight adhesion to the chest wall, The left upper lobe was then dis- 
sected free from the chest wall and mediastinum with particular attention to surgical margin. Bleeding from the intrathoracic artery were occluded with clipping. Finally, the phrenic nerve was exposed and preserved, and left upper lobectomy was completed. Operation time was 236 minutes and blood loss was 243 grams. Postoperative course was uneventful. The recurrent lung cancer after stereotactic body radiation therapy was successfully resected. 


\section{V6-5}

\section{原発性肺癌再発、第二肺癌に対する同側再切除術における注意 点〜主肺動脈確保の重要性}

\section{Resection of recurrent lung cancer and ipsilateral second primary lung cancer : Role of main pulmo- nary artery isolation}

○園部 誠、村西 佑介、濱路 政嗣、本山 秀樹、土屋 恭子、毛受 暁史、青山 晃博、陳 豊史、 佐藤 寿彦、伊達 洋至

京都大学医学部附属病院 呼吸器外科

OMakoto Sonobe, Yusuke Muranishi, Masatsugu Hamaji, Hideki Motoyama, Kyoko Hijiya, Toshi Menju, Akihiro Aoyama, Fengshi Chen, Toshihiko Sato, Hiroshi Date Department of Thoracic Surgery, Kyoto University Hospital

【背景】原発性肺癌区域切除後の局所再発や同側の第二肺癌に対する手術例が増加している。手術の安全性確保 が強く必要とされる。【対象と方法】2006/1 2016/11に、原発性肺癌切除術後再発例で、他に転移のない術側 と同側の局所再発ないし単発肺内転移に対して根治目的の切除を行った 6 例（M/F=4/2、57-80 yr）と、同側 の肺腫瘍に対する開胸手術歴のある原発性肺癌切除例 25 例（M/F=13/12、43-83 yr）を対象とした。部切 12 (手術時間 47-269 分、出血量 2-586 mL)、区切 6(177-388 分、2-608 mL)、葉切 5(200-568 分、80-2330 mL)、 残存葉切/二葉切/全摘 8 (201-553 分、30-775 mL)。術中の問題点と対策を検討した。【問題点と対策】再手術 が部切例、区切例では胸壁への癒着のみ。葉切、残肺切除 13 例では、1) 気管支断端瘻の危険性大>有茎肋間 筋弁、心膜周囲脂肪織による被覆。2）葉間部の肺動脈剥離が困難 $>10$ 例で主肺動脈確保を優先、肺動脈剥離 中の予期せ女損傷による出血への備えとした。初回手術のビデオで入りやすい血管の層がどこに残っているか の確認も重要。3)気管支断端や葉間切離の自動縫合器断端が血管壁に食い込むように癒着する部分あり>剥離 を断念し、より中枢での切離へ変更もやむを得ない。【ビデオ】右 S8 区域切除後の断端およびリンパ節再発例 への右中下葉切除を示す。【結語】主肺動脈確保を優先することにより肺動脈剥離中の安全性が確保される。自 動縫合器断端周囲の剥離には十分注意すべきである。

\section{Abstract}

Background : Resection of recurrent or second primary lung cancer has increased. During such surgery, avoidance of hazards should be needed. Patients and methods : Between 2006 and 2016, 6 patients undergoing pulmonary resection for recurrent lung cancer $(\mathrm{M} / \mathrm{F}=4 / 2,57-80 \mathrm{yr})$ and 25 receiving resection for ipsilateral second primary lung cancer $(\mathrm{M} / \mathrm{F}=13 / 1,43-83 \mathrm{yr})$ were analyzed. Operation mode was partial resection in 12 pts (operation time : 47-269 min., blood loss : 2-586 mL), segmentectomy in 6 (177-388 min., 2-608 mL), 
lobectomy in 5 (200-568 min., 80-2,330 mL), and completion lobectomy/bi-lobectomy/pneumonectomy in 8 (201-553 min., 30-775 mL), respectively. Results : In partial resection and segmentectomy, only pleural adhesion was impeding factor. In 13 lobectomy and completion lung resection cases : 1) Covering of bronchial stump with pedicled flap was mandatory : 2) Dissection of lobar branches of pulmonary artery was difficult so that, in 10 cases, isolation of main pulmonary artery was preceded so that unexpected bleeding of pulmonary artery was avoided. Prior operation record and video, if available, were helpful to find easily dissecting points. 3) Severe adhesion of surgical stapler line to vascular wall was often observed to give up dissection. Video presentation : Right middle and lower lobectomy after right S8 segmentectomy for recurrent lung cancerConclusion : With preceding taping of main pulmonary artery, dissection of lobar branch of pulmonary artery is performed safely. Adhesion around stapler line should be carefully dissected. 


\title{
V6-6
}

\section{卵巣癌術後転移性肺腫瘍術後再発に対して心衰内血管処理を要 した残肺全摘の 1 例}

\section{Completion pneumonectomy after right upper and middle lobectomy for metastatic lung tumor from ovarian carcinoma}

○王 志明、大内 健弘、鈴木 未希子、平山 俊希、福井 麻里子、小池 悠太郎、鈴木 潤、 小森 和幸、服部 有俊、松永 健志、松澤 宏典、今清水 恒太、高持一矢、鈴木 健司 順天堂大学医学部 呼吸器外科

Shiaki Oh, Takehiro Ouchi, Mikiko Suzuki, Syunki Hirayama, Mariko Fukui, Yutaro Koike, Jun Suzuki, Kazuyuki Komori, Aritoshi Hatori, Takeshi Matsunaga, Hironori Matsuzawa, Kouta Imashimizu, Kazuya Takamochi, Kenji Suzuki Department of General Thoracic Surgery, Juntendo University, Tokyo, Japan

【背景】肺悪性腫瘍術後に肺内再発した場合は、一般的に化学療法や放射線療法が行われることが多い。しかし 切除を必要とする症例もあり、その場合、癒着などにより再切除のリスクは非常に高くなる。今回卵巣癌術後 転移性肺腫瘍に対して、右上中葉切除を施行し、その後残右下葉に再発した症例に対して、心囊内処理を要し た残肺全摘の一例を経験したので、報告する。【症例】症例は 50 歳女性。1993 年に卵巣癌に対して手術施行。 その後 2010 年に肺転移に対して化学療法施行。その後右上中葉切除を施行した。2011 年に右下葉に転移が出 現し化学療法を施行するも効果なく、増大傾向を認めたため、2016 年手術施行。下肺静脈は心囊外で切離する も、上肺静脈断端と肺動脈が癒着していたため、心囊内処理とした。上肺静脈中枢側を心囊内で閉鎖。さらに 右肺動脈を根部で閉鎖切離した。気管支断端は心膜脂肪織で被覆した。術後経か良好で第 8 病日に退院となっ た。【結語】術後再発肺癌に対する手術は癒着などで、出血のリスクが高く、特に肺門処理を行う場合は、心囊 内処理による血管切離など慎重に行う必要があり、手技の向上に努める必要がある

\begin{abstract}
Background : In generally, recurrent malignant lung tumor after lung resection undergo chemotherapy or radiation therapy. But we sometime have to do reoperation. In that case, it is very high risk in operation, for example bleeding, adhesion. Case : Patient was 50 years old woman. In 1993, she underwent operation for ovarian carcinoma. After that, she underwent chemotherapy for lung metastasis in 2010. After chemotherapy we performed right upper and middle lobectomy. In 2011, she had recurrence right lower lobe again. She underwent chemotherapy again, but it was not effective. We performed re-operation. The operation was completion pneumonectomy. No irreversible procedures were performed until resectability was confirmed. We di-
\end{abstract}


vided pulmonary artery and upper pulmonary vein in pericardium and cut inferior pulmonary vein out pericardium. A pericardium fat pad was used to cover the bronchial stump. She discharged eighth post operative day without complication. Conclusion : Re-operation of lung is usually very high risk as adhesion, bleeding. In particular, when we remove hilar organ for example pulmonary artery, pulmonary vein and bronchus, we have to be careful. Furthermore, completion pneumonectomy is very high risk. We have to select a patient very highly to operate more safely. 


\section{V7-1}

\section{Transmanubrial Approachにより摘出した神経原性腫瘍 の 3 手術例の検討}

○杉田 裕介、石橋 洋則、栗原 泰幸、川田 悠、宇井 了子、熊澤 紗智子、高崎 千尋、小林 正嗣、 大久保 憲一

東京医科歯科大学附属病院 呼吸器外科

【はじめに】 Transmanubrial Approach（以下 TMA）とは Grunenwald が発表した肺尖部腫瘤へのアプローチ 方法の 1 つである。Pancost 腫瘍や頸胸部境界領域に発生した縦隔腫瘍に対し良好な視野展開ができるアプ ローチ方法として知られている。今回、TMAにより摘出した神経原性腫瘍を 3 例経験したので報告する。症 例 1】 24 歳女性。神経線維腫 1 型にて当院耳鼻科フォローされていた。フォローCTにて右頚部から胸腔内に まで進展する腫瘤を認め、一部右 Th1 神経と連続していた。術前診断神経線維腫 1 型悪性転化にて TMAによ る縦隔腫瘤摘出術を施行した。病理診断は神経線維腫であった。【症例 2】72 歳男性。既往は悪性リンパ腫、S 状結腸癌、気管支喘息。S 状結腸癌術前 CT で右上縦隔、傍椎体部に $26 \times 24 \mathrm{~mm}$ 大の腫瘤性病変を指摘された。 腫瘍内側は右 Th1 神経との連続性が疑われた。術前診断 Th1 発生神経原性腫瘍疑いに対し TMAによる腫瘍 摘出術を施行した。病理診断は神経鞘腫であった。【症例 $3 】 54$ 歳女性。健診にて胸部異常陰影指摘。胸部 CT では左上縦隔に境界明暸な $34 \times 22 \mathrm{~mm}$ の腫瘍を認め、腫瘍内側は $\mathrm{Th} 1 / 2$ 左神経孔にはまり込んでいた。術前診 断 Th1 発生神経原性腫瘍疑いに対し TMAによる腫瘍摘出術を施行した。病理診断は神経鞘腫であった。3 例とも術前 CT にて Th1 との連続性が疑われ、神経根での処理が必要と予想された。また、動静脈や神経叢が 密集し、十分な視野展開が難しい頸胸部境界領域において、良好な視野展開ができ、安全な手術が可能であっ た。術後も 3 例とも大きな合併症なく自宅退院となっている。【考察】高位胸椎より発生する神経原性腫瘍には TMA が有用である。 


\title{
V7-2
}

\section{両側胸腔に進展した巨大縦隔脂肪肉腫を clamshell ap- proach で摘出した 1 例}

\author{
○杉浦 八十生、藤本 博行、橋詰 寿律、加勢田 靜、根本 悦夫 \\ 独立行政法人国立病院機構 神奈川病院
}

症例は 50 歳、男性。主訴は労作時息切れであった。 5 年前の入社時健康診断で心拡大を指摘されたが医療機 関を受診していなかった。胸部 CT では腫瘍は縦隔から両側胸腔に進展し肺を著しく圧排し、大半が脂肪濃度 で一部石灰化を認めた。MRI では T1 強調、T2 強調画像ともに high intensity、脂肪抑制では low intensity であった。脂肪腫、脂肪肉腫、奇形腫が考えられ、clamshell approachによる腫瘍摘出術を予定した。両側の 第 5 肋間・前腋窩線を結ぶように乳頭の 2 横指尾側を経由して皮膚切開を設けた。胸骨を横切開しケント鈎で 頭側の胸壁を釣り上げ視野を展開した。胸壁と腫瘍との癒着剥離に大半を要したが肺、胸壁、縦隔への浸潤は 無かった。腫瘍重量は $3400 \mathrm{~g}$ 、手術時間 4 時間 25 分、出血量 $280 \mathrm{~g}$ であった。術前肺活量・1 秒量が $1.35 \mathrm{~L} 、 1.11$ Lであったが、術後 5 ケ月にはそれぞれ 3.04L、2.60L に改善した。病理所見は、大小不同の脂肪細胞様細胞か らなり奇怪な核を持つ腫瘍細胞を認めた。脱分化脂肪肉腫のマーカーの MDM2、cdk4 の発現は認めず高分化 型脂肪肉腫と診断した。術後 9 力月現在無再発で経過している。腫瘍病変に対して clamshell approach を用い た本邦での報告は、病変部位が気管分岐部にある症例に対して Sleeve pneumonectomy を行った症例が 3 例、 前縦隔の腫瘍に対して 4 例、両側腫瘍に対して 5 例であった。 1 つの腫瘍が両側胸腔に進展する本症例におい ても clamshell approach は有効であった。 


\title{
V7-3
}

\section{肺塞栓症で発症し、上大静脈・右房に進展していた胸腺腫}

\author{
○尾辻 瑞人?、小林 亜紀'、小野里 優希?、江花 弘基?、松永 裕樹'、輿石 晴也 ${ }^{2}$
} '都立墨東病院 胸部心臟血管外科、2都立大塚病院 外科

【はじめに】胸腺腫は胸膜や心膜、肺の隣接臓器への局所浸潤性が強く, 上大静脈内をポリープ状に腫瘍が進展 する報告は少ない. 今回, 肺塞栓症をきっかけに発見され、左腕頭静脈を閉塞、上大静脈・右心房まで進展し た胸腺腫に対し、化学療法に加えて 2 回の手術を施行した症例を経験したので報告する。【症例】 62 歳男性。 20xx 年 9 月カプセルホテルで倒れているところを発見、救急外来に搬送された。意識は回復したものの、造影 $\mathrm{CT}$ で両側肺動脈塞栓及び上大静脈の陰影欠損、9 $\mathrm{cm}$ 大の辺縁不整な前縱隔腫瘍を認めた。生検では胸腺腫が 疑われ、ヘパリン+ウロキナーゼの血栓溶解療法にて肺動脈主幹の血栓の消失を確認した。主たる塞栓が腫瘍 塞栓ではないと判断、1 か月後、胸骨正中切開下に腫瘍摘出、両側肺部分切除、左横隔神経合併切除、左腕頭 静脈合併切除・再建術を施行した。本手術において上大静脈から右房内の腫瘍が残存。invasive thymoma B3 であった。術後、全身状態回復後に化学療法を 2 クール施行。しかし翌 1 月には腫瘍の増大傾向、顔面・上肢 のむくみが出現した。突然死のリスクに加え、放射線治療では心筋障害の可能性が高いため、2 月残存腫瘍摘 出術を施行した。人工心肺を確立後、上大静脈前方を頭尾方向に切開し、内腔を確認、腫瘍の大部分は内腔側 にポリープ状に伸展し、右房に向かっていた。右心耳も切開し、ポリープ状の腫瘍を摘出した。術後、上大静 脈症候群は改善し、術後 1 か月退院。微小肺転移に対し化学療法を施行した。集学的治療の一環として本例は 完全切除ではなかったが、腫瘍負荷量を減らし、少なくとも突然死のリスクを下げることができた。 


\section{V7-4}

\section{上行大動脈に広く接した胸腺癌を心膜腔内からの剥離により完 全切除した一例}

○山本 直宗、上田 和弘、吉田 久美子、村上 順一、田中 俊樹、濱野 公一 山口大学 第一外科

【背景】上行大動脈に浸潤が疑われる胸腺癌は時に経験する. 心膜翻転部から腕頭動脈分岐直下までの大動脈で は, 心膜が大動脈壁へ生理的に癒着している. 同癒着は鋭的に剥離可能であり, 腫瘍を安全に切除するために は理解するべき局所解剖である，画像上、上行大動脈への浸潤が否定できなかったが，心膜の生理的癒着を鋭 的に剥離して腫瘍切除が可能であった症例を報告する.

【症例】75 歳, 男性. 半年間続く咳嗽に対する精査の胸部 CT で前縱隔に $75 \times 50 \times 50 \mathrm{~mm}$ の分葉状腫瘤を認め, CT ガイド下針生検で未分化癌と診断された。前縦隔腫瘍を疑い, 胸骨正中切開アプローチで手術を施行し た. 腫瘤は左腕頭静脈, 左内胸動静脈, 左横隔神経, 左肺上葉, 上行大動脈及び心膜に浸潤が疑われた. 左腕 頭静脈, 左内胸動静脈, 左横隔神経は中枢側及び末梢側でそれぞれ結紮または自動縫合器で切離した. 左肺上 葉は一部自動縫合器で合併切除した. 上行大動脈及び心膜では浸潤が疑われる部位より尾側の心膜を切開し, 心膜翻転部の内側から上行大動脈と心膜の生理的癒着を剥離する層へ侵入した. 腫瘍は上行大動脈壁へ浸潤し て抢らず完全切除できた．ビデオ発表では同部位剥離に関する手技を提示する，手術時間は 280 分，出血は $1015 \mathrm{cc}$ で, 術後経過に問題はなかった．胸腺原発大細胞性神経内分泌癌, 正岡分類 IVb 期, TNM 分類 IVb 期（T3N2M0）と診断し, 術後補助化学療法を計 4 コース施行した。術後 6 ケ月間経過し, 再発はない.

【結論】前縦隔腫瘍が上行大動脈に広く接する症例では, 一旦心膜腔内へ入ってから上行大動脈と心膜の生理的 癒着を鋭的に剥離すると切除が比較的容易となることがある. 


\section{V7-5}

\section{弓部大動脈置換および肺部分切除により完全切除し得た重症筋 無力症合併浸潤型胸腺腫}

○荒牧 直? 吉田 浩一'、村上 浩太郎? 、神谷 健太郎?、鈴木 隼? 丸野 恵大? 、矢野 由希子? 梶原 直央? 、大平 達夫? 、荻野 均? 、池田 徳彦 1

'東京医科大学 呼吸器- 甲状腺外科学分野、 ${ }^{2}$ 東京医科大学 心臟血管外科学分野

胸腺腫を合併する全身型重症筋無力症に対し, 拡大胸腺摘出術が推奨される。しかし, 大血管浸潤を伴う浸 潤型胸腺腫の手術報告は稀である。今回, 我々は大動脈に浸潤する重症筋無力症合併胸腺腫を切除し得た症例 を経験したため, 文献的考察を加え報告する。症例は 68 歳女性。眼瞼下垂と複視および與下困難で発症し, 前 医精查にて重症筋無力症と診断された。CT 画像で腕頭動脈・左総頚動脈・左鎖骨下動脈を取り巻く最大径 46 $\mathrm{mm}$ の前縱隔腫瘍と左頸部リンパ節の腫脹を認めた。穿刺吸引細胞診で胸腺腫が疑われた。神経内科・心臓血 管外科との討議を行い, 手術適応と判断した。胸骨正中切開および左頸部切開にて手術開始。腫瘍は左肺上葉, 左横隔神経, 左迷走神経, 無名静脈, 頸部 3 分枝, 左鎖骨下静脈, 左内澒静脈まで浸潤していた。弓部大動脈 置換, 無名静脈置換, 上葉部分切除を伴う拡大胸腺摘出術を行い, 胸腺腫を切除し得た。手術時間は 11 時間 41 分, 出血量は $3908 \mathrm{~mL}$ であった。術後 1 日目に人工呼吸器離脱・抜管。神経合併切除により反回神経麻痺 · 横隔神経麻痺を生じたが, 術後 2 週目には経口摂取可能となった。病理診断は, 胸腺腫, WHO 分類の B2 型, 正岡分類 III 期, pT4N3M0（pStageIV）であった。正岡分類 III〜 IV 期の胸腺腫は, 完全切除例で 5 年生存率 $90 \%$ の報告もあり，可能ならば外科切除が望ましい。 


\section{V7-6}

\section{右室流出路再建を伴う右肺全摘を行つた原発性肺動脈肉腫の 1 例}

○山本 陽子、新谷 康、舟木 壮一郎、谷口 聖治、久能 英法、神崎 隆、川村 知裕、南 正人、 奥村 明之進

大阪大学大学院 医学系研究科呼吸器外科学

【背景】原発性肺動脈肉腫は比較的稀な疾患であり、外科的切除を行わない場合は極めて予後不良とされてい る。今回我々は原発性肺動脈血管肉腫の一例を経験したので報告する。【症例】 30 代女性。右背部痛と血痰を 主訴に近医を受診。造影 CT で右肺動脈主幹部を閉塞する低吸収域を認め、肺動脈血栓塞栓症の診断で抗凝固 治療が開始された。しかし治療効果を認めず、PET-CT で同部位に FDG 集積立進を認めた。1 週間後の造影 CT では腫瘤影の明らかな増大を指摘されたため、肺動脈血管肉腫が疑われ当科紹介となった。右肺動脈はほ ほ腫瘍に占拠され急変の可能性が高いと判断し手術適応とした。【手術及び術後経過】胸骨正中切開を行い、人 工心肺を確立し心停止とした。肺動脈本幹を確認し切開し右主肺動脈の入口部を確認すると血栓とは異なる黄 白色の腫瘍が肺動脈に充満していた。肉眼的に腫瘍から離して右主肺動脈を起始部で離断し、肺動脈本幹側、 左主肺動脈側断端を術中迅速病理に提出したが両者とも陽性であった。肺動脈弁を含めて右室流出路および左 肺動脈は第一分枝 A3 直前まで切離し、生体弁と人工血管による再建を施行し、右肺全摘も追加した。術後病 理組織所見では肺動脈原発の intimal sarcoma、断端部は免疫染色で MDM2 陽性細胞を少数認めた。術後経過 は良好で術後 27 日目に退院し術後 4 ケ月現在外来で慎重に経過観察を行っており、再発を認めない。【まとめ】 原発性肺動脈血管肉腫の予後改善のためには完全切除を目指した積極的な切除が有効とされ、本症例では緊急 で右室流出路再建を伴う右肺全摘を施行した。切除断端陽性と判断し、慎重な経過観察を行っている。 


\section{V8-1}

\section{診断治療に苦慮した肺動眽原発血管肉腫の 1 例}

$\bigcirc$ 名部 裕介、今西 直子、由良 冴希子、小林 健一、松宮 弘喜、金山 雅俊、平良 彰浩、 篠原 伸二、桑田 泰治、竹中 賢、近石 泰弘、岡 壮一、平井文子、米田 和恵、田嶋 裕子、 黒田 耕志、田中 文啓

産業医科大学 第2外科

肺動脈原発血管肉腫は稀で予後不良な疾患である. 右室流出路狭窄による右心不全を呈し, 頓死することが ある，有効な放射線化学療法は確立されておらず，根治的手術療法が最も期待される，我々の経験した切除不 能の 1 例を報告する.【症例】 64 歳女性, 意識消失発作にて救急搬送. 単純 CT で肺癌の縦隔リンパ節転移と 肺動脈内進展を疑われて当院転院. 造影 CT で縦隔病変の主体は肺動脈本幹から両主肺動脈の第一分岐まで及 ぶ肺動脈内の造影欠損と判断され, 主肺動脈レベルで切迫閉塞状態であった. 心臓エコーで推定肺動脈収縮期 圧は $71 \mathrm{mmHg}$ と肺高血圧症を認め, 気管支鏡下肺生検や経静脈的カテーテル下生検は適応困難と判断され た. 臨床診断は肺動脈原発の血管内腫瘍となった，診断と治療，延命目的に手術を行った。【手術】PCPS下に 全身麻酔導入し, 胸腔鏡下右肺生検を施行. 迅速診断で血管肉腫の肺転移と診断されたが, 原発巣の可及的切 除を試みる方針．胸骨正中切開を行い人工心肺下に肺動脈本幹を切開したところ，血管内を充満する表面ゼ リー様灰白色の柔らかい腫瘍を認めた。腫瘍は広基性連続性に, 右は葉間肺動脈内まで, 左は下葉肺動脈内ま で達しており，中枢は肺動脈直上に及んだ。腫瘍は肺動脈壁に固着しており，腫瘍抜去は困難であった。肉眼 的完全切除には肺動脈弁置換と広範の肺動脈再建を要し, これは術式として成立しないと判断し切除を断念し た。心膜パッチを用いて肺動脈を形成し, 狭窄改善を図った。【経過】POD2PSPC を離脱, POD9 人工呼吸器 離脱, 術後肺動脈圧は $35 \mathrm{mmHg}$ まで改善し, POD62 独歩退院した. POM6 自宅療養中である. 


\section{V8-2}

\section{神経線維腫症 1 型に合併し、血管脆弱性が疑われた縦隔悪性神 経鞘腫の 1 切除例}

○村 奈緒子、若原 純一、山本 玲央那、森 遼、宮原 聡、早稲田 龍一、吉田 康浩、平塚 昌文、 山下 眞一、白石 武史、岩㟝 昭憲

福岡大学 呼吸器·乳腺内分泌·小览外科

44 歳男性。神経線維腫症 1 型の経過観察中に、縦隔腫瘍を指摘された。増大傾向があり、気管・左鎖骨下動 脈への圧排所見を認めたため、手術目的に当院紹介受診となった。CT で頸胸境界部、左鎖骨下動脈周囲に表 面平滑で不均一に造影される $6 \mathrm{~cm}$ の囊胞性腫瘤を認め、神経線維腫を疑い手術を行った。頸部襟状切開掞よび 胸骨正中切開で手術を開始。左頸部で総頸動脈、内頸静脈、迷走神経を同定し、腫瘍から剥離した。腫瘍は大 動脈弓頭側に存在し、左鎖骨下動脈、総頸動脈を圧排していたが剥離可能であった。腫瘍の剥離がすすみ可動 性がよくなったことで、鎖骨下動脈に過度の緊張がかかり損傷したが、直接吻合可能で修復しえた。術後は特 記すべき合併症なく退院された。病理診断は悪性神経鞘腫であった。神経線維腫症 1 型は $1 / 3500$ と比較的頻度 の高い常染色体優性遺伝であるが、悪性神経鞘腫の合併率は $2 \sim 6 \%$ と報告されており、胸腔内に発生した例は 比較的少ない。さらに、近年神経線維腫症 1 型における血管破綻のリスクに関する警鐘事例が報告され、神経 線維腫症 1 型のなかには血管脆弱性をもたらす血管病変が存在する事が報告されている。神経線維腫症 1 型合 併例を手術する際は、血管脆弱性を念頭に置き、慎重な手術操作が必要と考えられた。 


\title{
V8-3
}

\section{肺内型および縦隔型の気管支原性囊胞に対する完全胸腔鏡下手 術の 2例}

\author{
土井 健史、阪本 俊彦 \\ 神戸赤十字病院 呼吸器外科
}

【はじめに】気管支原性囊胞は発生部位により肺内型・縦隔型と分けられる。その両者に対し完全胸腔鏡下に襄 胞切除を行えた症例を経験したので報告する。【症例 $1 】 22$ 歳女性。健診で胸部異常陰影を指摘され当院紹介と なった。胸部 CT で肺動脈に接する襄胞性腫瘍が見られ、位置的に中縦隔の襄胞性腫瘍が高いと判断し診断・

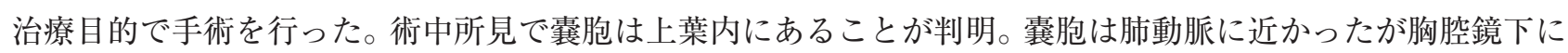
縦隔・肺動脈から剥離して襄胞核出を行うことができた。症例 2】56 歳男性。左胸水貯留の精查加療目的で当 院紹介となった。胸部 CT で中縦隔左側に囊胞性腫瘍が見られた。胸水貯留は囊胞破裂の影響も否定できず診 断・治療目的で手術を行った。術中所見で囊胞は肺外に存在し縱隔腫瘍であることを確認。周囲組織との癒着 は強かったが、胸腔鏡下に癒着を剥離し襄胞摘出を行えた。症例 1,2 とも病理所見で気管支原性囊胞と確定 し、術中所見から症例 1 は肺内型、症例 2 は縦隔型と診断した。【考察】気管支原性囊胞は成人では無症状のこ とが多いが、囊胞感染により症状が出現する場合もあり、特に肺内型の方で症状出現の頻度が高いとされてい る。症状出現後は高度炎症により囊胞と周囲組織が強く瘉着して囊胞のみの摘出が困難となり、肺葉切除など のより侵襲の高い手術が必要となる場合がある。症例 1 では囊胞が完全に上葉内に存在していたが、炎症所見 にそしかったこともあり、胸腔鏡下に襄胞核出のみを行い上葉を温存することができた。【結論】気管支原性囊 胞は、肺内型や炎症を起こした症例でも低侵襲手術が可能なことがあり、まずは囊胞のみの切除を試みるべき と思われる。 


\title{
V8-4
}

\section{重症能無力症に対する胸埶鏡下手術（単孔式手術の経験を含め て)}

\author{
嘉数 修、大田 守雄、當山 鉄男 \\ 中頭病院 呼吸器外科
}

【はじめに】重症筋無力症 (以下 $M G$ ) の手術手技はかなりの施設で胸腔鏡下手技が行われるようになった。手 技として胸骨吊り上げ法、剣状突起下法、一側アプローチ法、両側アプローチ法などがあり、それぞれ、手技 の工夫がなされている。当科では胸腔鏡下の一側アプローチを基本手術としており、澒部襟状切開を加えな い。最近では種々の工夫により単孔式による拡大胸腺摘出術も可能となった。われわれの手技の変遷と単孔式 手術について報告する。【対象および方法】当科で 2009 年 6 月から 2014 年 12 月まで当科において胸腔鏡下拡 大胸腺摘出術が行われた重症筋無力症 9 例を対象とした。【結 果】 2 例は 1port \& 1mini-thoracotomy, 7 例には単孔式胸腔鏡拡大胸腺摘出術を施行した。性別は男性 3 例、女性 6 例、年齢は 19 歳から 81 歳で平均 64.8 歳、手術時間は 113 分から 354 分で平均 237.2 分、出血量は 0 から $200 \mathrm{ml}$ で平均 $72 \mathrm{ml}$ 。胸腔ドレーンの留置は 最初の 4 例でその後の 5 例は留置していない。術後在院日数は 2 から 8 日で平均 4.3 日。胸骨正中切開への術 式変更はなかった。術前診断（Osserman 分類）は眼筋型（I 型）4 例、軽度全身型（IIA 型）2 例、中等全身 型 (IIB 型) 2 例、急性劇症型（III 型）1例であった。【手技の工夫】1. 体腔外での術者と助手の器具の干渉を 回避する目的でL 型コネクターおよびV ein harvest を使用した。2. 術者と助手の高さを変えることも器具の 干渉回避に役立った。3. 器具を先に胸腔内に挿入し続いて胸腔鏡で追尾する。【まとめ】1. 当科での拡大胸腺 摘出術の手技の変遷および術式の工夫について報告した。2.一側からの単孔式アプローチでも拡大胸腺摘出術 は充分可能である。 


\section{V8-5}

\section{CO2 送気下胸腔鏡下手術を行った多発性䯣外造血巣の 1 例}

$\bigcirc$ 桂 浩?、百武 威 1,2

りりんくう総合医療センター 呼吸器外科、䭪ヶ丘医療医療センター

髄外造血巣（以下、本症）は、時に、後縦隔の腫瘍性疾患との鑑別となる稀な疾患である。今回、画像上は 本症を疑ったが、典型的な随伴疾患を認めないため、外科的精査を行った症例を経験した。手技の供覧ととも に、若干の考察を加え報告する。【症例】76 歳男性。既往症は、高血圧、高脂血症、軽度肝機能異常。甲状腺 癌の術前 CT で、右後縦隔腫瘍を疑われ、当科を紹介された。腫瘤は、CT、MRIでは、第 9、第 10 胸椎右側 に最大 $5.6 \times 2 \mathrm{~cm}$ 、分葉状、内部不均一で、多発性であった。PETでは、2 程度の集積であった。なお、111 In シンチグラフィーでは、最大腫瘤と思われる部位に集積を認めた。手術は、 $\mathrm{CO} 2$ 送気下胸腔鏡下手術で行っ た。腫瘤は、画像通り、第 9、10 胸椎右側を中心としし、赤褐色調、壁側胸膜に覆われ、弾性軟、広基性であっ た。近傍にも、同様の病変が、散在していた。本症であれば、完全切除は不要と判断し、シンチグラフィーで 集積部と考えられたサイズの大きい第 10 胸椎腫瘤は避けて、より小さい第 9 胸椎腫瘤を選択した。En block の摘出を試みたが、腫瘤被膜は脆弱で、可及的摘出となった。術中は、CO2 送気で安定した術野が確保できた。 手術時間は 1 時間 54 分、出血は微量。術後経過に問題なく、 5 日目に退院した。病理学的には、骨髄類似の所 見であった。術後、血液内科での精査も異常なく、術後 2 年 5 ケ月経過の現在、放置した腫瘤にも変化なく、 経過観察されている。【まとめ】切除に際しては、詳細な画像検査とともに、十分な術野の確保、胁間静脈など の副損傷含めた出血に注意することで、易出血性との報告が多い本症だが、胸腔鏡下手術は、安全に実施可能 であった。 


\section{V8-6}

\section{当院における降下性壊死性縦隔炎に対する胸埶鏡下手術の工夫}

有賀 直広、壶井 貴朗、橋本 諒、矢ヶ崎 秀彦、松崎 智彦、大岩 加奈、濱本 篤、中川 知己、 河野 光智、増田 良太、岩崎 正之

東海大学医学部 外科学系呼吸器外科学

降下性壊死性縦隔炎 (descending necrotizing mediastinitis：DNM) は、歯科口腔領域の感染や咽喉頭感染が 降下性に縦隔まで波及した炎症性疾患である。重篤化しやすく予後不良な疾患であり、死亡率は 30 ～40\% とす る報告もある。治療は抗生剂治療と、早期の外科的ドレナージが最も重要な処置とされ、炎症の波及に応じて 積極的にドレナージを行う必要がある。Endo らの報告に基づく、Type $2 \mathrm{~A} / 2 \mathrm{~B}$ といった広範囲に膿瘍をともな う症例に関しては、胸骨正中切開や側方開胸によるアプローチが推奨されてきた。しかし骨の切除を伴い、皮 切が大きくなるような創部では術後骨髄炎や創部閉鎖不全などを合併し長期に感染コントロールが必要に なった症例も報告されている。また、DNM は敗血性ショックの合併例も多く、循環動態に配慮したより侵襲 の少ないアプローチが望ましいと考えられる。我々の施設では 2005 年 1 月から 2016 年 12 月までに Endo ら の報告にもとづく Type $2 \mathrm{~A} / 2 \mathrm{~B}$ の症例 9 例（Type $2 \mathrm{~A}: 1$ 例、2B $: 8$ 例）に対して積極的に胸腔鏡下手術を行 いこれれでの報告と遜色ない良好な結果を得てきた。創が小さくなる事により開閉胸の時間を短縮し低侵襲 に手術を行う事ができるとともに、胸腔鏡による拡大視や近接効果、開胸手術へのコンバートの容易さから安 全性も高められると考えている。当院での DNM に対する胸腔鏡下アプローチの工夫を実際の症例を交えて紹 介する。 


\section{V9-1}

\section{3 歲児の肺葉内肺分画症に対する完全鏡視下左下葉切除および 異常動眽切断術}

○奥村 典仁、大月 康弘、中園 千晶、本多 陽平、田崎 拓朗、山梨 恵次、高橋 鮎子、中島 尊、 松岡 智章

倉敷中央病院 呼吸器外科

乳幼児に対する完全鏡視下肺葉切除の報告は未だ少ない。これは 1. 分離肺換気が困難、2. Working Space が狭い、3. 小児用胸腔鏡 Instrument が開発されていない、等の点によるところが大きい。しかしながら、1. 微細血管・気管支の拡大視、2. 手術創の cosmetic な merit、3. 開胸による発育時の胸郭変形の回避、4. 創痛 軽減による術後管理の容易さ、等乳幼児ゆえのVATSの有用性も大きいものと思われる。今回われわれは 3 歳児の肺葉内肺分画症に対して、完全鏡視下左下葉切除㧍よび異常動脈切断術を施行し、良好な結果が得られ たため、その稀な手術動画を供覧する。【症例】 歳男児。出生時より胎児エコーで肺分画症を疑われていた。 正常分婏で正常出生後、呼吸状態も安定していたため、児の成長を待って待機的手術の方針とされた。胸部造 影 CT で PryceIII 型肺葉内肺分画症の診断で手術目的に当科へ紹介。【手術】Arndt 5 Fr の気管支ブロッカーを 用いた分離肺換気で全身麻酔。第 5 肋間前腋䆚線に皮切 $3 \mathrm{~cm}$ の 1 Window と第 $7 \cdot 8$ 肋間に $5 \mathrm{~mm}$ の 3 ports を扮き、 $5 \mathrm{~mm}$ 斜視鏡を用いてVATS を開始。開始後約 30 分は分離換気が不良で、手術操作不能であったが、 ブロッカーの微調整で改善した。まず下行大動脈から分岐する異常血管を同定し慎重に確保、自動縫合器で切 断。次いで葉間を剥離後、肺底動脈を自動縫合器で切断、さらに $\mathrm{A} 6$ を中枢側 2 重結紮切断。下肺静脈・下葉 気管支の順に自動縫合器で切断し、下葉切除を完了した。術翌日胸腔ドレーンを抜去。術後 3 日目からプレイ ルームで元気に遊ぶようになり、7 日目に退院となった。結語】分離肺換気が可能であれば、乳幼児に対して も本術式は安全に施行可能で、有用性も高いと思われた。 


\section{V9-2}

\section{ICG 蛍光ナビゲーションを用いて分画肺を切除した両側肺葉内 肺分画症の 1 例}

○山梨 恵次、奥村 典仁、大月 康弘、本多 陽平、中園 千晶、田崎 拓朗、高橋 鮎子、中島 尊、 松岡 智章

倉敷中央病院 呼吸器外科

肺葉内肺分画症の多くは片側であり両側肺葉内肺分画症は非常に稀である. 今回, 喀血を主訴に入院となっ た両側肺葉内肺分画症に対し, 喀血の責任病巣である左側に対して準緊急手術として完全鏡視下左下葉切除を 施行後, 二期的に右側に対して ICG 蛍光ナビゲーションを用いて完全鏡視下右分画肺切除を施行し, 良好な結 果が得られたので報告する.【症例】 38 歳男性. 幼少時より肺炎を繰り返していた. 2016 年 9 月喀血を主訴に 当院受診. 胸部 CT で, 下行大動脈から左肺底区に流入する異常血管および, 腹腔動脈から右肺底区に流入す る異常血管を認め, 両側 pryce III 型肺葉内肺分画症と診断した. また, 左 S6 に吸い込み像を認め, 左分画肺 が喀血の原因と考えられた，入院後も，喀血が継続したため，完全鏡視下左下葉切除を施行した，術後経過は 良好で一旦退院とし, 待機的に右分画肺の手術を行う方針とした。術式は左下葉切除施行後を考慮し, ICG 蛍光ナビゲーションを用いた右分画肺切除を選択した。【手術】第 5 肋間前腋窝線に $3 \mathrm{~cm}$ の小開胸創を置き, 第 7 肋間後腋窩線上, 第 7 肋間肩甲下角下, 第 8 肋間中腋窩線上にそれぞれポート作成を行い完全鏡視下で手 術を開始した．S10背側に分画肺を疑う領域を認めたが，正常肺との境界は不明瞭であった．異常血管を切離 後, 異常肺領域より下肺静脈に流入する静脈を切離した. ICG $(5 \mathrm{mg})$ を静注し, ICG 蛍光内視鏡を用い分画 肺と正常肺の境界を同定し, 境界を電気メスでマーキング後, 分画肺を摘出した. 経過は良好で, 呼吸状態も 安定したため, 術後 7 日目に退院とした. 


\title{
V9-3
}

\section{左肺動脈 $A 8 b+9 b+10 b$ が左主肺動脈から分岐した左肺下葉 S8+9 区域切除の 1 例}

\author{
$\bigcirc$ 持永 浩史、徳永 隆幸、田川 努
}

長崎医療センター 呼吸器外科

肺の血管分岐様式は多様であり、中でも手術時に注意を要するものの 1 つとて左肺動脈の縦隔型分岐があ る。今回我々は、 $\mathrm{A} 8 \mathrm{~b}$ と $\mathrm{A} 9 \mathrm{~b}$ と $\mathrm{A} 10 \mathrm{~b}$ が共通幹となって左主肺動脈より分岐した症例において、 $\mathrm{S} 8+9$ 区域切 除を行った極めて稀な 1 例を経験したので報告する。

症例は 60 歳男性。胸部単純レントゲン写真にて肺結節影を指摘。CTにて両肺全葉に結節影を認めた。右下 葉の solid 結節影に対して気管支鏡下生検を行い肺癌の診断。右上葉 S2 と左下葉 S8 には mixed GGA を認 め、他肺葉の結節影は pure GGA もしくは 5mm 以下の solid 結節影であった。Three Dimensional CT (3D-CT) 画像では左主肺動脈から A8b+9b+10b が縦隔型分岐を示していた。同時性原発性多発肺癌、cT1bN0M0 stage IA と判断し、右肺手術ののちに左肺手術を 2 期的に行うこととした。

2016 年 9 月、胸腔鏡下右肺下葉切除 $+N D 2 a-1+$ 右肺 $S 2$ 区域切除施行。経過良好にて術後 7 日目に退院。 2016 年 11 月、胸腔鏡下左肺 S8+9 区域切除 + 左肺上葉部分切除施行。術中所見では、S $8+9$ 区域切除に掠いて 3D-CT で認めた下葉肺動脈分岐の破格以外にも分岐を認めた。S8-9への区域肺動脈を各々結紮処理して区域 切除施行。経過良好にて術後 7 日目に退院。

今回、我々は左肺動脈下葉枝の一部が縦隔型分岐を有するという極めて稀な解剖学的破格を伴った下葉区域 切除を経験した。術前 3D-CT で肺血管分岐の破格を認識し、また術中にも $3 \mathrm{D}-\mathrm{CT}$ では認めない破格が存在し うる可能性を念頭において手術を行うことで、安全に胸腔鏡下肺区域切除を施行できた。 


\section{V9-4}

\section{遊離腹直矨皮弁で根治し得た慢性膿胸の 1 例}

○古賀 智子?、加藤 雅人?、高木 誠司 ${ }^{3}$ 、黒木 英男?、湯ノ谷 誠二 ${ }^{1}$

1唐津赤十字病院 外科、2ひらまつ病院 外科、 ${ }^{3}$ 福岡大学 形成外科

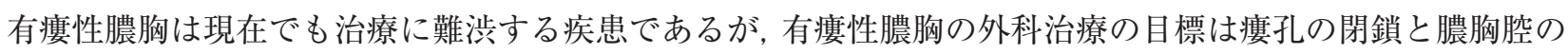
閉鎖である，この場合，大網や広背筋，大胸筋などが利用されるが，今回これらの組織が前回までの手術で使 用されていたために使用できず, 遊離腹直筋皮弁で膿胸根治術を行った症例を経験したので報告する.【症例】 47 歳男性【現病歴】1989 年に肺分画症に対し A 病院にて開胸下に右肺下葉切除術を受けたが, その後肺瘻を 併発し, 肺瘦閉鎖+右横隔神経切断術を施行された. その後も膿性痰が持続し, 23 年後に有瘦性膿胸を発症. $\mathrm{B}$ 病院で，大網＋前鋸筋充填術を受けた。しかし膿胸は完治できず， $\mathrm{C}$ 病院で右残肺全摘出術を受けたが，気 管支断端瘦による膿胸となり開空術と気管支断端に大胸筋被覆術を受けた. その状態で 2015 年 10 月に当院紹 介となった.【手術】左第 3 肋間で内胸動静脈を同定. 左腹部より $7.5 \times 28 \mathrm{~cm}$ 大の腹直筋皮弁を採取して膿胸腔 に充填した後, 深下腹壁動静脈と内胸動静脈を各々血管吻合した。気管支断端瘻は残存する大胸筋で被覆し た.【経過】術後は問題なく経過し術後 29 日目に退院した.【結語】3 度の手術で肺瘦からの膿胸を完治できず, 遊離腹直筋皮弁を用いることで完治し得た慢性有瘻性膿胸の一例を経験したので報告する。 


\section{V9-5}

\section{胸骨正中切開術後の縌郭咨に対しデブリドマンと一期的閉鎖に て制御した一手術例}

○下田 清美、中川 隆行、平松 美也子、吉田 勤、白石 裕治、荒井 他嘉司 結核予防会複十字病院呼吸器セン夕一 呼吸器外科

【はじめに】胸骨正中切開術後の縦郭炎は致死率の高い Surgical Site Infection である。今回我々は胸腺腫に対 する胸腺摘出術後に発症した縦郭炎に対してデブリドマンと一期的閉鎖にて制御しえた一例を経験したので 報告する。【症例】症例は 56 歳、男性。喫煙歴なし。糖尿病など背景疾患なし。人間ドックにて胸部異常陰影 を指摘され、当院へ紹介された。胸部 CT、MRIにて胸腺腫と診断され、胸骨正中切開下に胸腺摘除術を施行 した。術中、縦隔胸膜を破ったため両側開胸となった。術後 5 日目に発熱、6 日目からドレーン排液が膿性と なり、排液の培養結果から MSSAによる縦隔炎と診断された。術後 8 日目に再開創し、十分なデブリドマンを 行った後、縦隔にドレーンを 2 本留置し、胸骨を吸収糸 (PDS, $1 \mathrm{~mm}) 5$ 本にて縫合して、創を一期的に閉鎖 した。術後はドレーンに $-20 \mathrm{H}_{2} \mathrm{O}$ の強陰圧をかけ、ドレーンから生理食塩水による洗浄を $(500 \mathrm{ml}, 1$ 日 2 回) 行った。胸骨下スペースの縮小とドレーン排液の培養陰性化を確認して、再手術後 22 日後にドレーンを抜去し た。抗生剤(MEPM5 日間、SBT/ABPC25 日間、AMPC/CVA14 日間内服)は術後計 44 日間継続した。【考察】 本例はドレーンからの逆行性感染が発症機序として推定される。胸骨の骨䯣炎が成立する前であったこと、糖 尿病などの背景疾患がないこと、起因菌がMSSA であったことなどが幸いして感染制御が可能であったと考 える。我々が行なった方法は、適応となる病態は限られるが、再開創となる可能性も含めて患者に十分に説明 し、患者の理解と同意が得られるならば、試みてもよいと考える。 


\section{V9-6}

\section{胸骨プレート固定後に再手術を要した外傷性胸骨骨折の 1 例}

○城所 嘉輝、窪内 康晃、万木 洋平、若原 誠、三和 健、荒木 邦夫、谷口 雄司、中村 廣繁 鳥取大学医学部 胸部外科

外傷性胸骨骨折は比較的まれな骨折であり, 多くは保存的に治癒することが多い. 一方で転位が大きい場合 や, 疼痛が強い場合には手術適応となる，今回，外傷性胸骨骨折に対して観血的整復術を施行した 1 例を経験 したため, 若干の文献的考察を加えて報告する. 症例は 70 歳代男性. 自家用車で走行中に障害物を避ける際に ハンドル操作を䛊り受傷し, 胸部外傷にて前医へ救急搬送された。前医で CT を施行され, 胸骨骨折 GradeIV （I. Johnson \& T. Branfoot 分類）と診断されて加療目的に当院へ転院となった．入院後，胸骨骨折に対して全 身麻酔下で手術を施行した。胸骨整復後, ロッキングプレート（Sterna Lock Blu）を用いて固定した. プレー トは 12 穴タイプを使用し, 骨折線上を除いて合計 9 本のスクリューで片側の骨皮質のみを固定した. 術後は速 やかに疼痛が軽減し良好に経過したが, 術後 6 日目に前胸部の腫脹を認め, 胸部 X 線および CT でプレートの 脱落と胸骨再脱臼を認めた。翌日に再手術を施行し, プレートを除去して胸骨ワイヤーを 3 本使用して再固定 した. 再固定後は良好に経過し, 再手術後 8 日目に退院した。術後 7 ヶ月現在, 再脱臼等なく状態は良好であ る. 胸骨骨折に対しては従来, 胸骨ワイヤーによる固定法が行われてきた. 胸骨プレート固定は胸骨縦切開後 に用いる方法であるが, 近年では, 外傷性胸骨骨折に対する報告が散見され, 胸骨裏面の剥離が不要なことや 固定が容易であるため有用とされる. しかしながら, 本症例ではプレート固定術後早期に implant failure によ る再脱臼を認めため, プレート固定の適応やその際の注意点などを慎重に検討する必要があると考えられた. 


\section{V9-7}

\section{鳩胸に対して漏斗胸の金属プレート留置術(Nuss 法)を応用し た乎術}

○三浦 隆1、阿南 健太郎 1 、中城 正夫 ${ }^{2}$

'国家公務員共済組合連合会新別府病院 呼吸器外科、杵築中央病院

【はじめに】漏斗胸に対する Nuss 法は、変形肋軟骨の切除や胸骨の骨切りは行わずに正常胸壁の形状に合わせ た金属プレートを陥凹胸壁下に留置して矯正する方法で広く行われるようになった，一方、鳩胸の外科治療で は変形胁軟骨の切除、骨切りによる形成術(Ravitch 法)が行われているが、近年 Nuss 法を応用した金属プレー 卜留置術が報告されている. 今回、我々は沜胸の治療に対して当施設では初めて金属プレートによる矯正術を 行ったので報告する.【症例】 27 歳、男性. 剣状突起やや左側を中心とする突出変形と代償性に両側肋骨弓部 の陥凹を呈する. Nuss 法で用いる金属プレートを突出部では前方から圧迫し、陥凹部では胸壁下から挙上して 矯正することにした、【手術】胸壁の突出部で専用のテンプレートで胸壁の型どりを行い、専用ベンダーでプ レートの弯曲を作成. 貫通孔は陥凹部の両外側と突出部の両外側の計 4 力所に作成。突出部両外側の第 5 肋間 部を貫通して胸壁を押さえ、陥凹部両外側第 6 肋間部から外側胸壁にプレートを留置してスタビライザーで固 定することにした. 胸腔鏡も併用して専用のイントロデューサでガイドテープを留置後にプレートを左側から 胸腔 $\rightarrow$ 突出部前面 $\rightarrow$ 右胸腔 $\rightarrow$ 右胸壁へ誘導した. 弯曲プレート端を右胸腔から胸壁外へ誘導する際にかなりの 力を要した。両外側端は胸壁外でスタビライザーで固定した．矯正後の外観はほぼ正常の胸壁を呈し、矯正効 果は良好であった，手術時間 1 時間 27 分, 出血量 $26 \mathrm{ml}$. 【結語】鳩胸に対して Nuss 法を応用した金属プレー 卜留置術は、比較的簡便に低侵襲に行われ、十分な矯正効果も期待できることから有用な手技と考える. 


\section{V10-1}

\section{S6 区域切除+フラップ気管支形成術を行った気管支内過誤畽 の一例}

○川上 行奎'、青山 万理子'、河北 直也 ' 澤田 徹'、坪井 光弘 '、梶浦 耕一郎? 、鳥羽 博明?

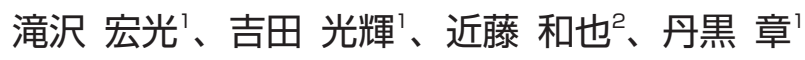

'徳島大学 胸部内分泌腫瘍外科、2徳島大学大学院 臨床腫瘍医療学

60 歳台，男性．契煙歴なし．PSO，HJI. 頻繁な咳を主訴に開業医受診. 投薬受けるも改善なく前医へ紹介さ れた. 胸部 CT にて左 B6 根部にポリープ状の腫瘍を指摘される. 内部は脂肪濃度が大部分であった. 気管支鏡 検査で B6 は表面平滑な腫瘍でほぼ閉塞しており, 腫瘍は可動性にそしかった。擦過細胞診が行われ classII. 画像所見から気管支内発生の過誤腫と思われ，治療目的に当院紹介となる. 良性腫瘍であり内視鏡的切除も検 討したが, 腫瘍の末梢側が観察不可能であり，S6 区域切除の方針とした．ただし腫瘍の局在から B6 気管支断 端の処理は下葉気管支へ切り込む必要があり，気管支形成を付加することを想定した．術中所見から B $6 \mathrm{a}, \mathrm{B}$ 6b は腫瘍とは離れており B6c に腫瘍の基部を確認できた. B6a, B6b の壁を温存しフラップ状にトリミング. これを下葉気管支壁の欠損部にあてがい縫合閉鎖した. 術後経過に問題なく第 8 病日に気管支鏡検査を行った 所, 気管支形成部の血流障害や変形もなく治癒過程は良好であった. 組織学的検査では術前診断通り脂肪成分 主体の良性過誤腫と診断された。 フラップ気管支形成術は楔状切除や管状切除に比べて合併症が少ないとさ れ，本症例の様な良性腫瘍に対する術式として有用であった。 


\section{V10-2}

\section{右肺スリーブ全摘術後、皮下気腫を契機に確認し修復しえた心 臓脱の 1 例}

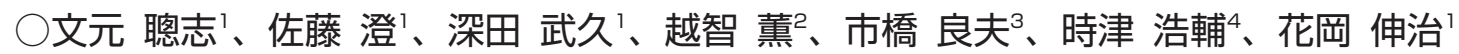
'大阪医科大学附属病院 呼吸器外科、 ${ }^{2}$ 北摄総合病院 呼吸器外科、 ${ }^{3}$ 八尾徳洲会総合病院 呼吸器外科、 ${ }^{4}$ 市立ひらかた病院 胸部外科

心膜切開を伴う肺癌術後の心臓脱は致死率の高い合併症として知られ治療には早急な外科的修復が必要と なる。我々は再発肺カルチノイドに対し右肺スリーブ全摘術を施行後、心臓脱を認め、再開胸により修復した 症例を経験したので文献的考察を加え発表する。症例は 59 歳女性。 8 年前に右上葉に生じた定型的肺カルチノ イドに対し胸腔鏡下右上葉切除術及びリンパ節郭清術を施行している。本年に入り労作時の息切れを主訴に来 院したため精査を行ったところ、肺カルチノイドの再発転移と診断された。腫瘍が気管分岐部に迫っていたた め、右肺スリーブ全摘術の方針とした。術中、下肺静脈は心囊外にて切離したが、上肺静脈と右主肺動脈は $\mathrm{T}$ 字に心膜を切開し心囊内で切離した。血管処理終了後、心膜は縫合閉鎖した。心膜と残存肺との間に癒着があっ ため頭側に $3 \mathrm{~cm} \times 2 \mathrm{~cm}$ の心膜欠損部が生じた。右主気管支と気管を切離し残存肺を摘出した後に、気管と左主 気管支を切離し端々吻合により再建した。吻合部に心膜脂肪織を被覆し手術を終了した。術後、激しい咳嗽を 契機に皮下気腫が出現し血圧も徐々に低下傾向を示したため術後 2 日目に再開胸とした。心膜欠損部から縫合 閉鎖した心膜を乗り越えるようにして心臓が右胸腔へと脱出、反時計回転し上大静脈は絞扼していた。心膜を 再度切開し心臓を元の位置に戻した後に Gore-Tex patchをあて修復した。術後経過は良好で術後20日目に 退院となった。心臓脱は予防が第一であり、肺全摘後の心膜欠損に対してはパッチによる閉鎖を考慮するとと もにドレーン管理や体位交換などの術後管理に対し細心の注意を払う必要がある。 


\section{V10-3}

\section{左肺上葉切除後の肺静脈断端血栓予防一左上肺静脈の心囊内結 紮一}

○朝井 克之、望月 孝裕、武井 健介、籾木 茂 浜松医療センター 呼吸器外科

左肺上葉切除後の肺静脈断端血栓は脳梗塞の原因となりうる重要な合併症として周知されつつある。現在、 日本呼吸器外科学会による「肺切除術後脳梗塞に関する周術期、手術因子の解析 : 多施設共同研究」が進行中 である。肺静脈断端血栓は長い残存左上肺静脈が主原因とされており、またいつでも生じうるという危険性を 孕む。予防策としては術後抗凝固療法または残存左上肺静脈を短くすることが考えられる。前者は常に出血の リスクを伴い、また半永久的となる可能性もあり、現時点では後者の方が現実的である。我々は、これまでに 左肺上葉切除後の肺静脈断端血栓の重要性を強く認識させられた以下の 2 症例を経験し、肺静脈断端血栓は肺 静脈を胸腔内で短く切離するだけでは予防できないという結論に達した。「左肺上葉切除術の翌日に内頝動脈 塞栓による広範な致死性脳梗塞を来し左上肺静脈断端血栓の関与が強く疑われた 1 例」「肺静脈を胸㛊内で短 く切離したにもかかわらず生じた左肺上葉切除後の左上肺静脈断端血栓の 1 例（大岩ら、日呼外会誌 2015 ; $29:$ 667-72.) 」。そのため、現在では左残存上肺静脈が長くなると判断された症例では、左上肺静脈を胸腔内で 切離後に心囊内での結紮を追加し断端を短くしている。肺静脈の心囊内処理は確立された手術手技であり、約 15 分の追加処置で半永久的な抗凝固療法が回避できる可能性がある。比較的容易な手術手技であるが、ビデオ で供覧する。 


\title{
V10-4
}

\section{Vessel-sealing System による血管・気管支損傷}

\author{
○前田 啓之、松居 真司、高木 雄三 \\ 鳥取県立中央病院 呼吸器乳腺内分泌外科
}

【はじめに】Vessel-sealing System（以下 VS）は胸腔鏡下手術の発展に大きく寄与し欠かせないものであるが 使用法には十分に注意する必要がある. 当院でもVS を積極的に活用しているが操作に関連した奇静脈・肺動 脈・気管支損傷例を 4 例経験し反省をふくめ報告する。【対象】 2013 年 1 月から 2016 年 11 月に当院で施行し た区域切除以上の原発性肺癌手術 195 例.VS は全例 Ligasure ${ }^{\mathrm{TM}}$ (Covidien Japan) で当初は Blunt Tip, 現在 は Maryland Jaw を使用している.【症例 1】奇静脈損傷例. 66 才男性. VATS 右肺上葉切除術. 術中出血量は $5 \mathrm{ml}$ であったが麻酔覚醒時の咳嗽を契機に胸腔ドレーンより多量出血があり再開胸. 奇静脈下縁の胸膜剥離の 際に奇静脈壁を一部 seal していたことによる後出血と判明し奇静脈を切断した. 【症例 2】肺動脈分枝損傷例. 65 才男性. VATS 右肺中葉切除術. 術前評価困難であった中葉肺動脈分枝をデバイス先端部で損傷し出血. 心 囊切開右主肺動脈クランプ後に縫合止血. 総出血量 $1250 \mathrm{ml}$. 【症例 3】気管支損傷例. 69 才男性. CVATS 左肺上葉切除術. リンパ節剥離操作の際に気管支膜様部を損傷. 損傷部中枢側で気管支切断.【症例 4】気管支 損傷例. 66 才男性. VATS 左肺上葉切除術. 気管支切断後の sealing テストにて切断部中枢側から空気漏れが 判明. 縫縮および心膜前脂肪による補強で閉鎖.【考察】血管鞘から血管を十分に剥離し先端を確認した上で使 用する必要があり, キャビテーションがないことを過信しての使用は危険である. 


\title{
V10-5
}

\section{術中心静止を来した 2 例の検討}

\author{
○塩谷 俊雄、久保 友次郎、片岡 和彦
}

独立行政法人国立病院機構岩国医療セン夕一 胸部外科

呼吸器外科領域の手術において不用意な操作は重大な合併症を招くこととなる可能性がある. 今回我々は, 術中操作が原因と思われた心静止を 2 例経験したため報告する.

症例 1 は 68 歳女性, 既往歴に特記事項はなく, 術前心電図でも異常所見は認めなかった. CT で左 S9に 19 $\mathrm{mm}$ 大の結節影を認めた. 左下葉肺癌（cT1aN0M0 Stage1A） と診断し完全胸腔鏡下左下葉切除術+ND2a-1 を施行した. 左下葉切除は定型通り終了し, 縦隔リンパ節郭清を行うため迷走神経本幹をテーピングしょうと 把持した. その瞬間, 突如心静止となった.アトロピン $0.5 \mathrm{mg}$ をすぐに投与し, 開胸の用意を進めた. その間, コットンで心臓を直接刺激したところ心拍再開を得た. 心静止時間は約 25 秒であった. その後循環動態の安定 が保たれたため，手術を続行し完遂した。術後は問題なく経過し独歩で退院した.

症例 2 は 52 歳女性, 既往歴に特記事項はなく, 術前心電図でも異常所見は認めなかった. CT で右 S3 に 33 mm 大の part solid GGN を認めた. 右上葉肺癌（cT2aN0M0 Stage1B）と診断し完全胸腔鏡下右上葉切除術+ ND2a-1 を施行した，右上葉切除は定型通り終了し，上縦隔リンパ節郭清を行っていた。迷走神経心臓枝をエ ネルギーデバイスで切離した瞬間, 突如心静止となった。すぐにコットンで直接心臟を刺激したところ心拍再 開を得た。心停止時間は約 15 秒であった，その後循環動態の安定が保たれたため，手術を続行し完遂した，術 後は問題なく経過し独歩で退院した.

術中心静止を来した報告は少ない. しかし, 対処が遅れると重大な事態を招く可能性も高いと考えられるた め, 日頃より予防策や対処方法を議論しておく必要があると思われた. 


\section{V10-6}

\section{拡大胸腺摘出手術施行後に胸骨ワイヤーの一部が右室内に迷入 し、摘出し得た一例}

○宮本 詩子、武田 雄二、岡本 祐介、野上 英次郎、島内 浩太、古川 浩二郎 佐賀大学医学部 胸部 · 心臓血管外科学

症例は 48 歳、男性。2010 年に重症筋無力症に対して胸骨正中切開下に拡大胸腺摘出術を施行され、以後、 ステロイド投与及び血漿交換などの内科的加療を継続されていた。本人の自覚症状はないものの、2015 年の胸 部レントゲンで頭側より第 $1 、 2$ 胸骨ワイヤーの破損と心陰影に重なる線状陰影を指摘された。胸部 CT 検査で は、胸骨は頭側で離開しており、右心室内に高輝度な線状異物の所見を認めた。胸部外傷や、重症筋無力症に 対する治療以外に特記すべき既往はなく、画像検查にて確認された異常陰影は、破損した胸骨ワイヤーの一部 が右心室内に迷入したものと判断し、一定期間の経過観察を行ったものの、今後の更なるワイヤーの変位に伴 う危険性を考慮し、2016 年に心腔内異物除去術を施行した。手術は、体外循環下に行い、右室心室中隔に埋没 していた同異物を抜去した(総体外循環時間 208 分、大動脈遮断時間 41 分)。異物は、肉眼的にも胸骨ワイヤー の一部と確認できた。今後、胸骨固定を必要とする手術術式において留意すべき点を、若干の文献学的考察を 踏まえて報告する。 


\section{V10-7}

\section{生体肺移植における肺静脈カフ形成術}

$\bigcirc$ 本山 秀樹、栢分 秀直、陳 豊史、郷田 康文、尾田 博美、上田 聡司、濱路 政嗣、土屋 恭子、 毛受 暁史、佐藤 寿彦、青山 晃博、園部 誠、伊達 洋至 京都大学医学部付属病院 呼吸器外科

【背景】生体肺移植ではドナーから左右どちらかの下葉をグラフトとして摘出し移植するが、ドナーの下肺静脈 の走行や分岐の形態により静脈カフの離断や短縮といったトラブルを生じ、肺静脈カフの形成を必要とする場 合がある。【対象】 2008 年 6 月から 2016 年 9 月に当院で施行した生体肺移植症例 (レシピエント 74 例、ドナー 134 例）の内、肺静脈形成を施行した 11 例について検討した。【結果】形成を必要としたグラフトは右下葉が 6 例、左下葉が 5 例で、術前造影 CTにていずれの症例も肺静脈の走行が確認可能であった。術前の状態は $\mathrm{V}$ 6 が底区枝の中枢で分岐していた症例が 3 例、V10 が下肺静脈の中枢付近から分岐していた症例が 2 例、V6 と底区枝が完全に分離していた症例が 2 例、V2 が下肺静脈に流入していた症例が 1 例、残り 3 例は正常分岐で あった。グラフト摘出時の状態は下肺静脈の分枝の完全離断が 6 例、不完全離断が 6 例（1 例は重複）であっ た。完全離断ではV 6 と肺底区枝が 4 例、V10 単独が 1 例、不完全離断ではV V 6 と肺底区枝が 4 例、V10 が 1 例、V6 と肺底区枝の不完全離断とV10 の完全離断の合併例が 1 例であった。形成方法は側々吻合によるカフ 形成が 6 例、レシピエント心膜による形成が 4 例、側々吻合 +レシピエント心膜による形成が 1 例で、いずれ も7-0proline による連続縫合を使用していた。再潅流後に吻合に起因するトラブルは認めなかった。結論】ド ナー肺静脈カフのトラブルは主に解剖学的理由により生じていたが、正常解剖例においてはクランプ位置など 技術的問題があった可能性がある。全ての症例で肺静脈形成により安全に対処可能であった。 


\section{V11-1}

\section{Wedge あるいは Flap 気管・気管支形成を工夫した肺癌切除 術}

○後藤 行延、荒木 健太郎、上田 翔、佐伯 祐典、北沢 伸祐、小林 尚寛、菊池 慎二、鈴木 久史、 市村 秀夫、佐藤 幸夫

筑波大学 呼吸器外科

気管・気管支形成を伴う肺切除では、近年、術前 3D 画像を含めたシミュレーション可能な術式である一方 で、術中判断により、最適な気管支形成デザインの変更・考慮を要する症例も少なくない。当科でこれまでに 行った肺癌に対する気管・気管支形成術のうち、腫瘍進展の具合から、術中判断にて、そのデザインを工し た 2 例を提示し、供覧する。症例 1 は 65 歳、男性。血痰を主訴に近医受診し、右下葉原発低分化型肺腺癌と診 断。CT にて CPFE を合併、右 S6 から中葉上葉肺門部背側に浸潤、LN11s と一塊になって右主気管支中枢まで 進展する大きさ $60 \mathrm{~mm}$ 大の腫瘍を認め、SUVmax : 22.7/28.3。LN11s 以外のリンパ節、その他に集積なし。気 管支鏡検査では下葉支は閉塞、右主気管支の mapping biopsy は negative であった。cT3N1M0, stage IIIA の診断で右肺全摘とした。術中所見で、右主気管支膜様部側の腫瘍浸潤は中枢に及ぶも剥離にて右主気管支は ステープラー切離可能、断端 negative となったものの、肉眼上、断端の腫瘍近接と、縫合部過緊張を伴う針穴 からのエアリークを認め、結果として、気管 deep wedge resection による右肺全摘とした。症例 2 は 71 歳、男 性。左肺下葉 S6に B6 入口部へ突出する腫瘍を認め、生検で扁平上皮癌の診断、cT2aN0M0 stage IB の診断で 手術の方針となった。下葉気管支から腫大したLN\#121 と一塊になった腫瘍を剥離するも、B6 から中間幹へ進 展する腫瘍を認め、術中所見にて B6 側中間幹から底区側に斜めに気管支を切離して、底区側の気管支面を flap として断端閉鎖に用いる flap-bronchoplastyによる下葉切除とした。 


\section{V11-2}

\section{S6 中枢肺癌に対して気管支切除断端の閉鎖を工夫した 2 例}

○小林 尚寛、荒木 健太郎、上田 翔、佐伯 祐典、北沢 伸祐、菊池 慎二、後藤 行延、佐藤 幸夫 筑波大学附属病院 呼吸器外科

気管支 B6 は下葉気管支の中枢で分岐するため, 右では中下葉分岐部, 左では上下葉分岐部に近接する. 従っ て, S6 の中枢肺癌では気管支断端が分岐部にかかってしまい, しばしば気管支狭窄の原因となる. 狭窄を避け るために気管支管状切除を行う方法もあるが, 糖尿病等の末梢血流障害の懸念がある場合には縫合不全等の合 併症が危惧される. 今回, 我々は糖尿病, COPD, 慢性腎不全等の併存疾患を有した S6 中枢肺癌で気管支断端 閉鎖を工夫した 2 例を報告する。症例 1. 75 歳，男性．右肺下葉 S6 中枢の扁平上皮癌 (cT2aN0M0 stage IB) で閉塞性肺炎を伴い，併存疾患で糖尿病，糖尿病性腎症，COPD 等を有していた。気管支切離に際し，切離線 を尾側（B7/8 側）は底区入口部から末梢に $5 \mathrm{~mm}$ ，頭側（B6 側）は中間気管支幹と B6 の分岐部とした斜め線 に設定した. 術中迅速診断で気管支断端陰性を確認し, 縫合閉鎖した. 術後中間気管支幹はやや狭くなったが, 開存は良好で問題なく経過した。症例 2. 71 歳, 男性. 左肺下葉 S6 中枢の扁平上皮癌 (cT1bN1M0 stage IIA) で, COPD, 慢性腎不全 (透析), 糖尿病等を伴っていた。気管支は, 背側 (B6 側)を上下葉分岐部で切離し, B8 側では断端閉鎖に用いるための Flap を作成しながら切離した。術中迅速診断で断端陰性を確認し、作成し た Flap を用いて気管支断端を縫合閉鎖した，術後は気管支狭窄もなく順調に経過した．S6 中枢肺癌症例にお いて, B6 の対側気管支壁 $(B 7,8$ 側)をやや長く残す工夫で気管支断端を合併症なく閉鎖することが可能であっ た. 


\section{V11-3}

\section{気管支・肺動脈管状切除を伴う左肺上葉切除、右肺上中葉切除 における肺血流遮断、気管支・肺動脈吻合の工夫}

○山田 徹、植田 充宏、熊田 早希子、篠原 周一、分島 良、渡辺 梨砂、松岡 隆久、長井 信二郎、 松岡 勝成、宮本 好博

NHO姫路医療センター 呼吸器外科

【背景】気管支・肺動脈管状切除を伴う左肺上葉切除、右肺上中葉切除では通常の肺葉切除手術手技に加えて血 管遮断、気管支、肺動脈吻合に工夫を必要とする。【症例】症例 173 才男性。左肺上葉完全無気肺を伴う上葉 気管支入口部の扁平上皮癌。症例 251 才男性。縦隔リンパ節腫大。LN\#4R より EBUS で肺扁平上皮癌と診 断。術前導入化学療法 CBDCA+nabPTX を 3 コースで縮小認めたが SD、cyT2aN2M0。右上葉気管支入口部 に腫瘍の浸潤を認めた。手術】硬膜外麻酔チューブは手術前日に留置。症例 1 では胸腔鏡下に葉間の肺動脈剥 離、左肺全摘回避が可能であることを確認したのちに後側方切開第 4 肋間開胸。上肺静脈の切断、リンパ節郭 清、および葉間切離まで終了した上でヘパリン $300 \mathrm{u} / \mathrm{kg}$ 静脈内投与し、5 分間の両肺換気。主肺動脈は血管鉗 子で遮断、下肺静脈を血管テープ、ターニケットで遮断。肺動脈末梢側の遮断は行わない。気管支吻合は 3-0 Vicryl 糸 RB-1 針を用いて症例 1、2 ともに 16 針の全周単結紮縫合。肺動脈吻合は 6-0 Prolene 糸を用いて 2 点支持連続縫合。【結果】症例 1、2 の手術時間は 225 分、311 分、術中出血は $212 \mathrm{~g} 、 281 \mathrm{~g}$ 、主肺動脈遮断時間 は 70 分、57 分であった。症例 $1 、 2$ ともに術後 2 日目に胸腔ドレーン抜去。症例 1 で吸痰のため 2 回の気管支 鏡の後に輪状甲状勒帯切開チューブを 4 日間留置したが、術後 13 日目、7 日目に退院。病理組織診断結果は症 例 1 は LN\#12u に転移を認め pT2aN1M0。症例 2 は EF2、ypT2aN2M0 であった。【結語】気管支・肺動脈管 状切除を伴う左肺上葉切除、右肺上中葉切除における当科での血管遮断、気管支、肺動脈吻合の工夫を供覧す る。 


\section{V11-4}

\section{左右腕頭静脈合流部に浸潤した肺癌に対する血行再建の工夫}

○岡本 龍郎、庄司 文裕、松本 拓也、古山 正、豊川 剛二、上妻 由佳、松原 太一、原武 直紀、 高森 信吉、赤嶺 貴紀、高田 和樹、桂 正和、前原 喜彦

九州大学 消化器·総合外科

【背景】上大静脈に浸潤する肺癌に対しては、人工血管を用いた切除再建術が行われることが多いが、人工血管 は術後に閉塞することが多く、長期経過において問題になることがある。【症例】 70 歳男性。右上葉原発肺腺 癌、右腕頭静脈から上大静脈に広く接しており、cT4N0M0、StageIIIAの診断となった。術前化学放射線療法 を施行され、手術の方針となった。【手術所見】胸骨縦切開にて手術を開始。腫瘍は右腕頭静脈から上大静脈遠 位部まで背側に浸潤を認めた。まず右前胸部第 3 肋間に横切開を加え、浸潤部位を残した上葉切除を行った。 腫瘍浸潤は右腕頭静脈から合流部付近の上大静脈までにとどまっていた。左腕頭静脈は温存可能と考えられた が、血管形成時に上大静脈の全血流遮断が必要と判断し、一時バイパスを置くことにした。左腕頭静脈から上 大静脈へ径 $8 \mathrm{~mm}$ のヘパリンコート・リング付き PTFE 人工血管を端側吻合にて一時バイパスを作成した。次 に右腕頭静脈から SVC の血流を遮断後、左腕頭静脈から SVC の左側壁を残しつつ、浸潤部位の血管を腫瘍と 共に切除し上葉切除を完了した。残した SVCを直接縫合し左腕頭静脈を再建した。さらに、一時バイパスで用 いた人工血管の末梢部を左腕頭静脈より切離し右腕頭静脈の切離端に端々吻合し、右腕頭静脈を再建した。術 後経過は良好で、 2 週間後に造影 CTにて人工血管の開存を確認した。【まとめ】左右腕頭静脈合流部に浸潤し た肺癌に対し、術前治療後に上大静脈の血行再建を工夫することで、人工血管の使用を最小限にし、既存の血 管を温存することができた。 


\section{V11-5}

\section{左鎖骨下動脈合併切除・人工血管置換を伴った左上葉肺腺癌の 一例}

$\bigcirc$ 中道 徹、橋本 昌樹、黒田 鮎美、多久和 輝尚、松本 成司、近藤 展行、長谷川 誠紀 兵庫医科大学病院 呼吸器外科

はじめに:肺尖部原発性肺癌は主要血管への浸潤をしばしば認め、完全切除のために人工血管置換を必要とす ることがある。症例：60 歳代、男性。咳嗽を主訴に受診し、CT で左肺尖部結節を指摘。気管支鏡を施行する も診断には至らなかった。腫瘍は左鎖骨下動脈と大動脈弓に接するも画像上は明らかな浸潤はないと判断し、 診断治療目的に左上葉切除術+リンパ節廓清を計画した。右側臥位で手術を開始。術中、大動脈弓への直接浸 潤は認めなかったが、左鎖骨下動脈への直接浸潤を認めたため、腫瘍を一部離断する形で左上葉切除を施行 し、仮閉創。仰臥位へ体位変換した後に第 2 肋骨上縁までの L 字型胸骨部分切開を置き、第 1 胁骨を腹側で離 断した後、残存腫瘍にアプローチ。L 字型胸骨部分切開、第 1 肋骨離断によって鎖骨下動脈の基部を含めた良 好な視野を得ることができ、人工心肺を用いずに左鎖骨下動脈の部分遮断のみで合併切除・人工血管置換 (リ ング付きゴアテックス $8 \mathrm{~mm}$ 人工血管、約 $8 \mathrm{~cm}$ ) が可能であり腫瘍の完全切除を得た (手術時間 : $9 \mathrm{~h} 48 \mathrm{~min}$ 、出 血量 $270 \mathrm{~g})$ 。術後に左反回神経麻痺、軽度 Horner 症候群を認めるもおおむね経過に問題なく、POD17に軽快 退院となった。病理診断の結果、鎖骨下動脈への浸潤を認める肺腺癌であり、pT4N0M0 との診断に至った。 人工血管閉塞予防にバイアスピリンの内服を行い、現在術後 5 か月経過するも、人工血管閉塞を含めて特に合 併症なく経過している。まとめ: 左鎖骨下動脈合併切除・再建によって完全切除可能であった左肺腺癌を経験 したので手術ビデオを供覧する。 


\title{
V11-6
}

\section{導入照射化学療法後, 上大静脈・左腕頭静脈合併切除置換術を 要した胸腺癌の 1 切除例}

\author{
○伊部 崇史 1 上吉原 光宏 $、$ 河谷 菜津子'、大沢 郁1 、吉川 良平 ${ }^{1}$ 、清水 公裕 $^{2}$ \\ 1前橋赤十字病院 呼吸器外科、群馬大学付属病院 外科診療也ン夕一
}

はじめに: 胸腺腫瘍は, 上大静脈や左腕頭静脈へ浸潤することがあり, 合併切除を要する場合は右心耳への血 行再建方法が問題となる. 今回我々は, 左腕頭静脈, 上大静脈を $\mathrm{Y}$ 字状に血行再建を施行した胸腺癌の 1 切除 例を経験したので報告する。症例 : 66 才男性. 他疾患精査の際, 胸部異常陰影を指摘され当科紹介. 胸部 CT で前縦隔に径 $78 \mathrm{~mm}$ の腫瘤を認めた，左腕頭静脈・上大静脈・上行大動脈に広く接し腫瘍浸潤が疑われた. CT ガイド下腫瘍生検により胸腺癌と診断された。放射線療法 60Gy・化学療法 (CBDCA+PTX) 2 コース後, 腫瘍が縮小 $(\mathrm{PR})$ し外科的切除術を施行した. 手術 : 胸骨正中切開で施行. 腫瘍は大動脈とは剥離しえたが, 左腕頭静脈, 上大静脈, 右肺上葉への浸潤を認めた. 左腕頭静脈, 上大静脈の両者を Y 字状に血行再建して腫

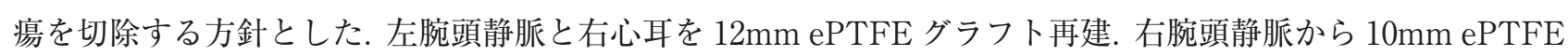
を先のグラフトへ端側吻合し Y 字再建とした. 血行再建後, 上大静脈, 左腕頭静脈, 奇静脈を切除し腫瘍を摘 出した. 手術時間 7 時間 0 分, 出血量 $240 \mathrm{ml}$. 抗凝固療法を術当日より開始し軽快退院. 術後 4 力月現在外来 通院中である. まとめ: 左腕頭静脈・上大静脈と右心耳を $\mathrm{Y}$ 字状に血行再建することで, より生理的な血行動 態がえられ静脈圧増大を回避することが可能となる. 


\title{
V $11-7$
}

\section{気道狭窄を来した気管浸潤甲状腺癌に対し頚部気管 4ring を 合併切除した 90 歳女性の一例}

\author{
○立道 佳祐、清水 淳三、林 沙貴、守屋 真紀雄、亀水 忠 \\ 北陸中央病院 呼吸器外科
}

気道狭窄を伴う気管浸潤甲状腺癌に対し䅡部気管 4ring の合併切除および端々吻合による一期的な再建を 施行し良好な経過を得た一例を報告すると共に，その手術手技をビデオで供覧する.【症例】 90 歳女性. 血痰 および喘鳴を主訴に近医を受診し, 精査の結果, 甲状腺癌の気管浸潤による気道狭窄と診断され, 手術の目的 で当科紹介となった，頝部 CT 検査では，甲状腺右葉に石灰化を伴う $2.5 \times 2.0 \mathrm{~cm}$ 大の結節を認め，これが気管 内腔に露出し著明な気道狭窄を呈していた，気管支鏡検查では，易出血性の甲状腺癌の突出を認め, 気道狭窄 の程度は最大で気管断面の約 $75 \%$ と判断した。気管浸潤範囲は約 $2 \mathrm{~cm}$ で, 総頚動脈および内頚静脈への浸潤 はなかった.【手術】皮切は䅡部襟状切開に上部胸骨正中切開を追加, 甲状腺右葉切除に第 $2 \sim 5$ 気管軟骨輪を 合併切除して甲状腺癌の完全切除を行い, 気管を一期的に端々吻合して再建した．断端の挫滅を回避するた め, 気管の切離はすべてメスを用いて鋭利的に行った。再建時, 術野で口腔に向け逆行性に無菌の挿管チュー ブを挿入し直すことで, 以降の無菌的な手術操作の継続に努めた. 術後 1 週間はミニトラック II を留置して吸 痰処置を行い, 頚部は前屈位に固定した。術後の経過は良好であり, 第 28 病日に退院した。【考察】気管管状 切除・端々吻合術を行う際には, 気管を愛護的に扱う, 栄養血管を温存する, 無菌的な手術操作に努める, 気 管の授動を行い確実な縫合操作に努めるなどに留意し, 縫合不全や吻合部狭窄などの合併症の発生を減少させ る努力が必要である。本症例は 90 歳という超高齢者であったが良好な術後経過が得られた。 


\title{
V 12-1
}

\section{左下葉切除術後の肺癌気管支断端再発に対する completion pneumonectomy}

\section{Left completion pneumonectomy for the recurrent lung cancer : Surgical skill and daily training}

\author{
後藤 太一郎、中込 貴博、樋口 留美 \\ 山梨県立中央病院呼吸器外科 \\ OTaichiro Goto, Takahiro Nakagomi, Rumi Higuchi \\ Dept. of General Thoracic Surgery, Yamanashi Prefectural Central Hospital
}

肺癌術後の再発症例に対して再手術を行う際、術後の癒着、特に血管処理において困難な局面に遭遇するこ とが多い。よって、術前の画像/臨床所見から癒着、腫瘍浸潤を想定し、適切な手術戦略を計画することが肝要 である。今回、我々は左下葉切除術後の肺癌気管支断端再発の一例を経験した。通例、左下葉切除術後の再手 術においては初回手術の及ぼす影響は限定的とされるが、本症例では気管支断端部の再発巣が上肺静脈、肺動 脈、食道に浸潤していたため、心囊内血管処理、気管支切離、最後に食道からの腫瘍剥離の順を選択した。心 囊は一部合併切除し、腫瘍を完全切除した。手術手技を中心にビデオを供覧し、心囊内血管解剖、適切な手術 戦略の構築につき考察を加え、発表する。一方、左上葉切除術後の再手術においては、胸腔内で肺動脈と大動 脈との癒着が想定されるため、“PA elongation”の手技が必要とされる。我々は、定期的に豚生体を用いた手 術トレーニングを行い、PA elongation など高難度手技の習得を試み、安全な手術の実践へ還元したいと考えて いる。豚生体トレーニングにおける PA elongation 手技のビデオを供覧し、手技のポイント・注意点につき考 察を加え、発表する。

\section{Abstract}

Adhesion caused by the initial surgery often makes the following completion pneumonectomy challenging, especially when the major pulmonary vessels strongly adhere to the surrounding tissues. Elaborate preoperative assessment of the adhesion site and careful planning for the surgery is mandatory to achieve a safe and curative treatment. We present a case of recurrent lung cancer located at the bronchial stump of the initial left lower lobectomy. Although the completion pneumonectomy after the left lower lobectomy, as a rule, is not so complicated, in this case, the recurrent cancer directly invaded the upper pulmonary vein, pulmonary artery, and the esophagus, requiring intra-pericardial surgical procedures followed by the tumor dissection from the esophagus. Thus, en-bloc resection of the tumor was performed without any complications. Herein, we will demonstrate the surgical skills used and how we elaborated the preoperative plan, with a review and consideration of intra-pericardial vessel anatomy. On the other hand, the completion pneumonectomy after 
the left upper lobectomy is far more critical and almost contraindicated in some cases due to the adhesion between the pulmonary artery and the aorta. In preparation for such critical cases, we make it a rule to perform periodical training using a live porcine. Utilizing the animal model, we will show the technique of so-called PA elongation, and elucidate the critical point of that procedure. 


\section{V12-2}

\section{右 S3 区域切除後に右 S2 に発生した二次肺癌に対して残存肺 上葉切除を行った一例}

\section{Completion right upper lobectomy for secondary lung cancer after right S3 segmentecomy}

○和田 啓伸、伊藤 祐輝、椎名 裕樹、佐田 諭己、豊田 行英、畑 敦、稲毛 輝長、田中 教久、 坂入 祐一、藤原 大樹、中島 崇裕、鈴木 秀海、岩田 剛和、千代 雅子、吉野一郎 千葉大学大学院医学研究院 呼吸器病態外科学

OHironobu Wada, Yuki Ito, Yuki Shina, Yuki Sata, Takahide Toyoda, Atsushi Hata, Terunaga Inage, Norihisa Tanaka, Yuichi Sakairi, Taiki Fujiwara, Takahiro Nakajima, Hidemi Suzuki, Takekazu Iwata, Masako Chiyo, Ichiro Yoshino General Thoracic Surgery, Chiba University Graduate School of Medicine

症例は 50 歳代の男性。約 6 年前に多施設共同臨床試験に登録し右上葉肺腺癌に対して右 S3 区域切除 +リン パ節郭清（ND2a-1）を行った。病理病期 T1aN0M0， stage IA で経過観察されていたが、約 2 年前より右 S2 に緩徐に増大する結節を認め気管支鏡検查で肺腺癌と診断された。二次肺癌（cT1aN0M0, IA）と診断し、可 能な限り右中下葉を温存する方針で手術に臨んだ。後側方切開をおき第 5 肋骨床で開胸した。初回手術時の第 4 肋間開胸創の強固な癒着は胸膜外で剥離した。上縱隔にも強固な癒着を認め、心囊内で上大静脈の確保を試 みたが、裏面の癒着が強く肺門処理を先行した。上中葉間分離のためトンネリングを試みたが葉間肺動脈から 出血したため、先に確保していた V1+2 を切離し、心膜剥離後に右肺動脈本幹を遮断、下肺静脈を遮断、さら に上中葉間をステープルで形成し、葉間肺動脈を遮断し止血を得て肺動脈損傷部位を修復した。背側から奇静 脈を切離すると、上大静脈と上葉の癒着部位が展開されたので鋭的に剥離した。上幹肺動脈を切離した後に葉 間から $\mathrm{A} 2 \mathrm{~b}$ の確保を試みたが、上葉気管支分岐部は㓔痕化しており剥離困難で、最終的には A2b 肺実質と ともに結紮後切断した。上葉気管支管状切除・再建を考慮したが、周囲の癒着が強く過大侵襲になると判断 し、上葉支末梢を区域枝レベルで切断して残存上葉切除を完了した。手術時間は 4 時間 53 分、出血量は 835 $\mathrm{g}$ であった。術後乳び胸水を認めたが脂肪制限食と癒着術で軽快した。第 7 病日にドレーンを抜去し第 9 病日 に退院となった。最終病理診断はAd,、pT1aN0M0、IA で完全切除を確認した。

\section{Abstract}

A patient, who underwent right S3 segmentectomy for adenocarcinoma (cTlaN0M0, IA) about 6 years ago registered multicenter randomized clinical trial, had a gradually increasing nodule in remnant right upper lobe in his fifties. The nodule was diagnosed as adenocarcinoma with bronchoscopy and other imaging modalities revealed no metastasis, leading to the diagnosis as secondary lung cancer (cTlaN0M0, IA). Completion 
right upper lobectomy was planned. Posterolateral skin incision was made and thoracotomy was performed via fifth inter-costal space. Severe adhesion was observed between the lung and chest wall due to the initial thoracotomy and was dissected extrapleurally. Upper mediastinum was also severely adhered and superior vena cava (SVC) could not be encircled. While dividing upper and middle lobe, interlobar pulmonary artery (PA) was injured requiring isolation of $\mathrm{V} 1+2$, clamping the stem of right PA and peripheral PAs branching from the interlobar PA, and inferior pulmonary veins. After the repair of PA and separation of upper and middle lobes, azygos vein was desected which was effective to divide the upper lobe and SVC. The first branch from the PA was isolated, however, ascending A2 could not be identified due to severe adhesion, leading to tie and cut it with surrounding lung parenchyma. Right upper segmental bronchi were stapled together, leaving scar tissue surrounding bifurcation between upper and intermedius bronchi because bronchoplasty was determined to be avoided due to its invasiveness. The operative time was 4 hours and 53 minutes, the bleeding was $835 \mathrm{~g}$. Postoperative chylothorax was recognized and successfully treated with fat suppressed meal and pleurodesis. The chest tube was removed on post-operative day (POD) 7 and he went home on POD9. The pathological diagnosis was adenocarcinoma, completely resected, pTlaN0M0, IA. 


\section{12-3}

\section{右肺下葉切除後の S5 区域切除術}

○橘 啓盛、渋谷 幸見、三ツ間 智也、長島 鎮、田中 良太、武井 秀史、近藤 晴彦 杏林大学医学部 外科学 (呼吸器·甲状腺)

症例は 79 歳の女性, 4 年前に右下葉肺癌に対して右下葉切除, ND2a- 2 , 肋間筋弁による気管支断端被覆術 を施行した. 浸潤性粘液性腺癌, 腫瘍径 $10 \mathrm{~cm}, \mathrm{pT} 3 \mathrm{~N} 0 \mathrm{M} 0$ stage IIB であった. 術後に UFT を 2 年間内服し, 以後は経過観察されていた. 術後 4 年経過したところで, 右 S5 に浸潤影が出現し, 徐々に増大してきたため, 気管支鏡下生検を行い粘液性腺癌と診断された。リンパ節転移や遠隔転移はなく, 局所再発もしくは肺転移の 診断にて再切除の方針とした。 下葉切除後かつ気管支断端には肋間筋弁が被覆されており, 中間気管支幹や葉 間での中間肺動脈切離を必要とする残中葉切除は困難であると予想されたため, マージンを確保した S5 区域 切除の予定で手術を行った。 開胸創背側や肋間筋弁付近などに癒着がみられたが, それ以外には癒着を認めな かった. 上肺静脈周囲は前回手術でそれほど操作していなかったが, 胸膜に炎症性変化がみられ剥離にやや難 渋した. V5， B5，A5 を切離した後に V4 の枝を一部切離しながら，自動縫合器で葉間や区域間を切離し， S 5 区域切除を行った. 残 S4 の拡張は良好で, 合併症なく術後 9 日目に軽快退院した. 術後時間が経過し残中葉 の容積が大きくなっている場合は，中葉の区域切除も選択肢の 1 つと考えられた. 


\section{V12-4}

\section{右上葉切除後の残存下葉に発生した第 2 癌に対する術式選択に ついて}

\section{Selection of surgical procedure for second pri- mary lung cancer occurring in the remained right lower lobe after right upper lobectomy}

$\bigcirc$ 橋本 雅之、赤澤 彰、苗村 佑樹、賀来 良輔、片岡 瑛子、川口 庸、五十嵐 知之、大塩恭彦、 寺本 晃治、手塚 則明、花岡 淳

滋賀医科大学 呼吸器外科

OMasayuki Hashimoto, Akira Akazawa, Yuki Namura, Ryosuke Kaku, Yoko Kataoka, Yo Kawaguchi, Tomoyuki Igarashi, Yasuhiko Oshio, Koji Teramoto, Noriaki Teduka, Jun Hanaoka

Division of Thoracic Surgery, Shiga University of Medical Science, Otsu, Japan

初めに: 右上葉肺癌に対する右上葉切除後に、残存右下葉に第 2 癌が発生した場合、解剖学的切除術は難度が 高い。特に残存肺全摘を避け、中葉を温存する際には高難度手術となる。これは先行手術時の血管処理やリン パ節郭清、葉間作成等により胸壁・葉間が癒着するだけでなく、肺門部肺動脈の確保が困難なことや、切除後 に胸腔内の死腔が大きくなること、切離した下葉気管支断端への血流不全など様々な問題点をはらんでいるた めである。今回、残存右下葉に発生した第 2 癌に対し中葉を残した上で、異なる術式を選択した 2 症例を提示 する。症例 $1: 61$ 歳、男性。2009 年に右上葉肺癌に対し開胸右上葉切除術を施行された。2015 年に右残存下葉 に結節影が出現し増大したため、気管支鏡検查を施行。診断は得られず、手術による診断加療の方針とした。 後側方切開第 5 肋骨床開胸とし、右 S9+10 区域切除術を施行した。気管支断端は絹糸で単結紮切離した。現在 術後 1 年半経過したが再発なく、術前と変わりない生活を送っている。症例 $2: 73$ 歳、男性。2015 年に右上葉 肺癌に対し VATS 右上葉切除術を施行された。2016 年 3 月右残存下葉の増大した陰影より CT 下生検で肺腺 癌を認め、第 2 癌と診断、手術加療の方針とした。後側方切開第 5 肋骨床開胸とし、右下葉切除術を施行した。 B6 は絹糸で単結紮切離し、底区支は自動縫合器で切離した。術後 4 か月目に底区支断端瘻から膿胸を発症し、 開空術を施行した。現在も連日の包交を要している。結語：縮小手術を選択する理由として腫瘍の性状、残存 肺機能が理由となることが多いが、上記のような複雑な状況では、手術の安全性や合併症の観点から、より積 極的に縮小手術を考える必要がある。

\section{Abstract}

INTRODUCTION : If a second primary lung cancer occurs in the remained right lower lobe (RLL) after right upper lobectomy for the right upper lobe (RUL) lung cancer, an anatomical resection is difficult. Especially 
when preserving middle lobe to avoid completion pneumonectomy, the operation is highly difficult. This is not only because of the adhesion of the chest wall or lobe caused by a prior surgery, but It is because it has various problems such as the difficulty to secure the pulmonary artery in the hilar region, remaining the large dead space in the thoracic cavity and the failure of blood flow to the bronchial stump. In this study, we present two cases in which selected different surgical procedures for a second primary cancer occurring in the remained RLL. CASE 1: A 61-year-old man. Since the nodular shadow appeared and increased in the remained RLL after right upper lobectomy, the right S9+10 segmentectomy was performed. The segmental bronchus was ligated and cut off. Currently, he is living well without recurrence of the tumor. CASE 2 : A 73year-old man. Because a pulmonary adenocarcinoma was diagnosed by CT-guided biopsy in the remained RLL, right lower lobectomy was performed. The 6th segmental bronchus was ligated and cut off, and the basal segmental bronchus was cut with staplers. Four months after the surgery, an empyema developed from the basal bronchus fistula and the open window surgery was performed. CONCLUSION : When selecting sub-lobar resection or not, it is considered about the tumor character and the residual lung function. However, from the viewpoint of safety and complications of surgery, we should consider a sub-lobar resection in these complicated situation. 


\section{V12-5}

\section{右 S6 区域切除術の 2 年後に右下葉切除術を施行した 1 例： 酸化再生セルロースシートの癒着防止における有効性}

○水谷 栄基、中原 和樹、宮永 茂樹、清家 彩子

東京逓信病院 呼吸器外科

手術に㧍ける癒着防止材として, 酸化再生セルロースは安全に癒着発生を減少することが示されている (Lancet2014；383：48-59). また, 気胸再手術において周囲組織への癒着が見られないことを経験する. 我々 は, 区域切除術の 2 年後に右肺下葉切除術を施行し, 再手術時の癒着防止において酸化再生セルロースシート が有効であったと考えられた 1 例を経験したので報告する. 症例は 44 歳女性. 既往歴は帝王切開のみ. 喫煙歴 なし. 42 歳時に肺ドックの胸部 CT で右肺 S6 区域に $1.5 \mathrm{~cm}$ 大のすりガラス様陰影を認めた。その他の両肺野 に $5 \mathrm{~mm}$ 以下の淡い陰影が多発していた，半年間で陰影変化を認めず，高分化肺腺癌の疑いにて胸腔鏡下右肺 S6 区域切除術を施行した. minor air leak の制御及び癒着防止目的に, 区域間形成面に酸化再生セルロース シートを貼付した. 組織学的には minimally invasive adenocarcinoma と診断した. 術後 2 年目の CT 検査で右 肺残下葉内に新規に多発する小陰影を認めた。診断と治療目的に手術を施行した。まず胸腔鏡で胸腔内を観察 し，癒着の程度で開胸へ移行する方針とした，手術所見では，葉間部の癒着はほぼ認められず，葉間部肺動脈 を確認できた．前回手術の影響と考えられる組織肥厚を認めたが，完全鏡視下に下葉切除が可能であった．組 織学的には最大病変が $1 \mathrm{~cm}$ 大であり, 肺胞上皮置換性成分を主体とし管状や乳頭状の成分を伴う高分化〜中 分化腺癌であった. 数年前から我々は, 再手術が予想される症例に扔いて切離面に酸化再生セルロースシート を貼付している，その有効性については，今後の症例の蓄積により明らかになっていくと考えている. 


\section{V12-6}

\section{肺癌術後気管支断端瘦に対し胸腔鏡下にて断端バルーン閉鎖洗 浄後に大網断端牽引固定が奏功した 1 例}

○古屋敷 剛'、須田 一晴1、近藤 晴彦²、吳屋 朝幸²

1新潟厚生連長岡中央線合病院呼吸器外科、2杏林大学医学部附属病院 呼吸器外科

【要旨】気管支断端瘦は肺癌術後最も治療が困難となる合併症のひとつである。今回同合併症の非侵襲的な手術 的アプローチを経験し奏功したので報告する。【症例】 65 歳男性。2013 年 7 月右下葉肺炎にて当院へ入院治療 され外来通院していた。2016 年 3 月肺炎部の瘷痕が腫瘍変化し PET 検査などで肺癌が疑われ当科へ紹介と なった。同一肺葉内に転移が疑われ T3N0M0 STAGE IIB 診断にて同年 4 月 25 日に完全鏡視下右下葉切除 ND 2-a2 郭清を施行した。腺癌 pT3 (PM) NOM0 STAGE IIB の診断であった。 5 月 10 日発熱にて受診。気管支鏡 検查にて気管支断端瘦と診断され 5 月 13 日胸腔鏡下にて断端を小児用尿道バルーンカテーテルにて閉鎖し、 ウロキナーゼ洗浄を数日施行。炎症反応が落ち着いたところで 5 月 20 日完全鏡視下にて経気管切開的に大網 を気管支断端瘦に谹引固定胸腔内充填を施行した。再手術後感染傾向なく、気管支鏡検査にて断端部大網の固 定を確認し術後 20 日にて退院となる。 


\section{13-1}

\section{血友病 A 患者の大腸癌肺転移に対する完全胸腔鏡下右肺中葉・ S3 畽瘍切除}

○齋藤 雄史、立松 勉、千馬 謙亮、佐竹 章、山川 洋右

卜ヨ夕記念病院 呼吸器外科

【はじめに】先天性血友病 $\mathrm{A}$ 患者に対する完全胸腔鏡下右肺中葉・ $\mathrm{S}^{3}$ 腫瘍切除手術を経験したので報告する。 【症例】 67 歳男性、他院にて大腸癌術後に右転移性肺腫瘍を認め紹介となった。既往歴： 4 年前に直腸癌手術、 2 年前に肛門部播種再発巣の手術歴。幼少時からの出血症状歴はなかった。CT では、右肺 $\mathrm{S}^{4}$ の $30 \mathrm{~mm}$ 大の充 実性結節が不全分葉の上中葉間を超えて $\mathrm{S}^{3}$ へ浸潤、 $\mathrm{S}^{3} \mathrm{~b}$ には $18 \mathrm{~mm}$ 大の別の充実性結節を認めた。術前検査で APTT 40.5 秒、再検查でも延長有り、血液凝固因子の精査を行った。第 8 凝固因子活性は $17 \%$ 一低下、第 9 、 11、12 因子、フォン・ウイルブランド因子は正常值内、第 8 凝固因子インヒビターは検出しなかった。初期の 後天性血友病 A も鑑別となったが、前医問い合わせにて以前より APTT 延長が確認され、先天性血友病 A 軽症と診断した。血友病患者に対する止血治療ガイドラインに準拠して、周術期は第 8 凝固因子製剂を補充し 右肺中葉切除 $+\mathrm{S}^{3}$ 区域 ( $\mathrm{S}^{3} \mathrm{~b}$ 亜区域) 切除の方針とした。手術は、 $\mathrm{V}^{4+5} 、 \mathrm{~B}^{4+5} 、 \mathrm{~A}^{4+5}$ 、中下葉間の順に切離、中葉 気管支血管処理を終えたが、易出血性の術野環境であったため、区域切除手術操作を控え、 $V^{3} a b$ 処理後、 $V^{2}$ c、 $V^{1} b$ を温存して、 $S^{3}$ 領域を 3 葉合流部から肺門前面に向けて大きく肺部分切除して右中葉・ $S^{3}$ 腫瘍切除を 行った。手術時間 4 時間 29 分、術中出血量 356ml、周術期はAPTT 確認しながら術後 7 日目まで第 8 凝固因 子製剂を使用した。【まとめ】血友病 $\mathrm{A}$ 軽症患者に凝固因子製剤を補充して手術を行ったが、術野では易出血 傾向を認め、術中に手術術式の再検討を要した。凝固系が問題となる頻度はまれであるが、過小評価しないよ う注意する必要がある。 


\section{V13-2}

\section{$\mathrm{B}^{2}$ 転位気管支を伴う右上葉肺癌に対する完全胸腔鏡下右肺 $\mathbf{S}^{1+3}$ 区域切除術}

千馬 謙亮、齋藤 雄史、立松 勉、佐竹 章、山川 洋右 卜ヨ夕記念病院 呼吸器外科

【はじめに】まれな気管支分岐異常（右 $\mathrm{B}^{2}$ 気管支が $\mathrm{B}^{4+5}$ 基部へ転位）を伴う右上葉肺癌手術を経験したので、 術前評価、手術手技、気管支転位について報告する。【症例】72 歳女性、検診胸部異常陰影にて紹介となった。 $\mathrm{CT}$ 検査では右肺 $\mathrm{S}^{1}$ に長径 $2.7 \mathrm{~cm}$ 、左肺 $\mathrm{S}^{3}$ に長径 $1.2 \mathrm{~cm}$ の辺縁スリガラス陰影を伴う結節と左肺 $\mathrm{S}^{1+2}$ 中枢に 1 $\mathrm{cm}$ の限局性スリガラス陰影、PET 検査では右肺 $\mathrm{S}^{1}$ 腫瘍に SUVmax1.6 の軽度 FDG 集積を認めた。右 $\mathrm{B}^{1+3}$ 気管 支は主気管支より通常分岐したが、右 $\mathrm{B}^{2}$ 気管支は $\mathrm{B}^{4+5}$ 基部より起始し肺動脈裏側を通り背側へ上行してい た。右上葉肺動脈は、上幹 $\mathrm{A}^{1} \mathrm{ab}+\mathrm{A}^{3} \mathrm{ab}$ 以外に $\mathrm{A}^{4+5}$ から $\mathrm{A}^{2} \mathrm{~b}$ 枝、 $\mathrm{A}^{6}$ から $\mathrm{A}^{1} \mathrm{a}$ 枝と $\mathrm{A}^{2} \mathrm{a}$ 枝が分岐する変異を認め た。上下葉間は外側面に一部分葉あるが、上中葉間には分葉を認めなかった。両側上葉腫瘍に対し、完全胸腔 鏡下に右 $\mathrm{S}^{1+3}$ 区域切除、2 期的に左上大区切除の方針とした。右肺手術は、分葉不全が強いため前方アプローチ で手術を進め、血管・気管支処理後 $\left(V^{1} b 、 V^{3} \mathrm{cV}^{3} b V^{3} a 、 V^{2} \mathrm{cV}^{1} a 、 \mathrm{~A}^{1+3} 、 \mathrm{~B}^{1+3} 、 \mathrm{~A}^{1} \mathrm{a}\right.$ の順)、最後に上葉 $\mathrm{S}^{3} /$ 中葉間、 $\mathrm{S}^{3} / \mathrm{S}^{2} 、 \mathrm{~S}^{1} / \mathrm{S}^{2}$ 区域間を切離した。【まとめ】気管支分岐異常例では、気管支のみならず分葉や血管分岐に解剖学 的変化を伴う事があり、肺切除手術に際して注意を要する。本症例では、CT 画像、3D 構築画像による解剖学 的条件の充分な理解、手術手順の術前検討により安全な胸腔鏡下手術を行う事ができた。 


\section{V13-3}

\section{分葉不全症例に対する完全鏡視下解剖学的右 S3 区域中葉一塊 切除術}

○石角 太一郎1、片場 寛明'、伊藤 哲思'、池田 徳彦 2

1戸田中央総合病院 呼吸器外科、2東京医科大学 呼吸器甲状腺外科

【はじめに】悪性腫瘍に対して区域手術を行う際には、断端再発を防ぐために病変と切離断端との距離を十分に 確保しなければならない。しかしながら、鏡視下手術では媣部に存在する腫瘍の切除マージンを確認すること はしばしば困難であり、断端再発の誘因となる。我々の施設では術前に $3 \mathrm{D}-\mathrm{CT}$ を用いてシミュレーションを 行い、マージンを確実に担保できる切除区域を予め決定している。今回我々は、上中葉完全不全分葉症例にお ける S3 と中葉にまたがる腫瘍に対して完全鏡視下右肺 S3 区域中葉一塊切除術を施行した。【症例】84 歳女 性。左肺 $\mathrm{S} 1+2$ に $2.5 \mathrm{~cm}$ 大の結節と右肺 $\mathrm{S} 3$ から中葉にまたがる $2 \mathrm{~cm}$ 大の $\mathrm{GGO}$ 病変を認めた。画像上は共に肺 癌を強く疑う所見であった。まず左肺結節にて対して左肺上大区域切除およびND2a-1 を施行した。術中迅速 にて腺癌の診断を得た。p-T1bN0M0 stage IA。術後の全身状態が良好であったため右肺病変に対しても手術の 方針となった。CT 所見では上中葉間は分葉不全であり腫瘍は S3 から中葉に及んでいた。術前に $3 \mathrm{D}-\mathrm{CT}$ を用 いたシミュレーションを行い、S3+中葉合併切除でサージカルマージンを確保できることを確認した後、完全 鏡視下解剖学的右 S3 区域中葉一塊切除術を施行した。術中迅速にて腺癌との診断を得た。p-T1bN0M0 stage IA で切除断端陰性を確認した。分葉不全症例における拡大区域切除の術前評価ならびに手術手技を供覧す る。 


\section{V13-4}

\section{完全鏡視下での安全な左肺動脈上幹 stapling について〜実証 と理論}

○伊藤 温志、高尾 仁二、小林 晶、島本 亮、新保 秀人

三重大学医学部附属病院 胸部心臟血管外科

【背景】左肺動脈上幹 $(\mathrm{A} 3, \quad \mathrm{~A} 1+2 \mathrm{a}, \mathrm{b})$ は分岐様式が多様で剥離できる距離も短く、鏡視下による上幹 stapling は血管損傷リスクが高い操作のひとつである。目的と方法】完全鏡視下での自動縫合器による左肺動脈上幹切 離において、肺門前方あるいは肺門後方からの左肺動脈上幹に対する stapling 操作を比較し、安全な処理法を 考察する。【結果】当科のアプローチは第 7 肋間中腋窩線上からの $30^{\circ}$ 斜視鏡を用いた見上げ式 VATS である が、左肺動脈上幹に対する stapling 方向は術者間あるいは同一術者においても統一されていなかった。 $<1>\mathrm{A}$ 3 が比較的中枢で亜区域枝に分岐した場合や A 3 と A1+2 が共通幹の場合では、肺門前方からの視野では血管 分岐部の確認が困難であった。肺門後方からの視野では血管分岐部が比較的容易に視認でき、安全に自動縫合 器を挿入しやすい。<2>左肺動脈上幹を肺門前方から背側に向かうアプローチでは肺動脈本幹長軸に対して 上幹分枝は垂直方向に stapling され、肺門後方から腹側に向かうアプローチでは肺動脈本幹長軸に対して上幹 分枝は平行に stapling される。上幹断端 (stump) に働く剪断力は肺動脈本幹長軸に対して垂直方向に stapling された場合の方が強く、肺動脈本幹に近接して stump が短く stapling された場合には stump 閉鎖部の破たん の可能性が危惧された。結語】左肺動脈上幹の stapling は肺門後方からのアプローチが安全であると考えられ た。しかし、本アプローチにも自動縫合器の先端を確認しにくいという問題点もあり、留意すべき操作上のコ ツについても併せて述べる。 


\title{
V13-5
}

\section{完全胸腔鏡下右下葉・中葉切除における\# $11 \mathrm{~s} \rightarrow 12 \mathrm{u} \rightarrow 10$ 連続廓清手技をマスターするための当院での取り組み}

\author{
$\bigcirc$ 平野 豊、鷲尾 一浩 \\ 公立学校共済組合中国中央病院 呼吸器外科
}

【はじめに】連続したリンパ節廓清を意識した右下葉または中葉切除を行う場合、特に完全胸腔鏡下に行う場合 には\#11s $\rightarrow 12 \mathrm{u} \rightarrow 10$ 廓清を正確に行うことにしばしば難しさを感じるが、Asc.A2 を温存しつつ\# $12 \mathrm{u}$ 廓清を 行う事に原因があると考えている。当院では Asc.A2 を切離する右 $\mathrm{S} 2$ 区域切除時の＃ $12 \mathrm{u}$ 廓清を経験した後に $\# 11 \mathrm{~s} \rightarrow 12 \mathrm{u} \rightarrow 10$ 連続廓清を伴う右下葉または中葉切除を行うようにしている。【方法】手術は 1 window（2３ $\mathrm{cm})+3$ ports で行っている。右 S2 区域切除時には、Asc.A2 切離し、Tr.superior ・右上肺静脈・右上葉気管支 を taping し適切に牽引しつつ B3 同定しながら\#12uを一塊で廓清している。Asc.A2 を切離しているため視野 確保もしやすく鉗子操作の制限も軽減され比較的容易である。また Rec.A2 切離しているため Tr.superior の テーピングも幾分容易となる。右下葉または中葉切除時には、Asc.A2・Tr.superior・右上肺静脈 (中葉切除に はV1〜3）・右上葉気管支を taping し牽引しながら B3 同定後に\# $12 \mathrm{u}$ を一塊にして廓清している。【結果】現在 まで 3 名の術者が上記手順で手技を安全・正確に行えるようになった。【考察】右 S2 区域切除を行う際に Asc. $\mathrm{A} 2$ 切除する $12 \mathrm{u}$ 廓清を経験した後に Asc.A2 を温存しながら\#11s $\rightarrow 12 \mathrm{u} \rightarrow 10$ 廓清を伴う右下葉または中葉 切除をマスターしていくのが合理的と考えられる。【とめ】当院での取り組みを若干の考察を加え報告する。 


\section{V13-6}

\section{完全鏡視下縦隔腫瘍切除術における CO2 送気による人工気胸 の長所と短所}

○内田 嚴、松原 寛知、市原 智史、松岡 弘泰、佐藤 大輔、山元 奏志、塚原 悠、鈴木 章司、 中島 博之

山梨大学 第二外科

近年完全鏡視下による縦隔腫瘍切除術は一般的なアプローチの一つとなっている。その際に CO2 送気によ る人工気胸は視野展開の一つの手段として用いられている。当科における完全鏡視下縦隔腫瘍切除例について の成績と CO2 送気の有効例、無効例についてビデオ供覧する。成績は 2005 年 3 月より 2016 年 8 月において完 全鏡視下縦隔腫瘍切除を行った 39 例について後方視的に検討した。CO2 送気の有無により患者背景（性別、 年齢、腫瘍の位置)、手術デー夕 (体位、手術時間、出血量、ポート数、創長)を比較検討した。CO2 送気に よる人工気胸は肺の虚脱と胸腔の拡大により視野が改善することや出血の軽減が図れるといった長所がある とされる。一方で、呼吸循環動態が不安定化することや、空気塞栓の懸念があるといった短所が指摘されてい る。残念ながら視野の改善が手術デー夕の改善に直結するわけではなく、統計学的に CO 2 送気による人工気胸 の有効性について示すことは難しい。今回当院における完全鏡視下縦隔腫瘍手術においても統計学的にCO2 送気例の CO2 非送気例に対する有用性を示すことはできなかった。しかし、はっきりと視野の改善を認めた症 例は存在し、CO2 送気による有害事象も特に認めなかった。完全鏡視下手術において良好な視野を得られるこ とは明らかに有用な点である。それにより視野展開に要するポートを減らすことができ、手術時間の短縮が望 める。考察する中で腫瘍の存在する解剖学的位置が有効か否かを分ける一つの要因と考えられた。当科の成績 と有効例と無効例についてビデオで供覧する。 


\title{
V 13-7
}

\section{剣状突起下アプローチ拡大胸腺胸腺腫摘出術の一例}

\author{
○立松 勉、齋藤 雄史、千馬 謙亮、佐竹 章、山川 洋右
}

卜ヨ夕記念病院 呼吸器外科

【はじめに】当院では 2016 年から前縦隔腫瘍に対し積極的に剣状突起下アプローチ手術を施行している。今 回、重症筋無力症合併胸腺腫に対し剣状突起下アプローチで拡大胸腺胸腺腫摘出術を施行した 1 例を経験した ので報告する。【症例】 62 歳、女性。1 か月前から右眼瞼下垂が出現し近医より当院紹介受診となった。右眼瞼 下垂以外の症状はなく、テンシロンテストは陰性であったが、抗アセチルコリンレセプター抗体は 1.5 と陽性 で重症筋無力症 (MGFA 分類：1）と診断された。精查の胸部造影 CT で前縦隔の左腕頭静脈下に長径約 $5 \mathrm{~cm}$ の境界明瞭な充実性腫瘤を認めて重症筋無力症合併胸腺腫の術前診断で、剣状突起下アプローチ拡大胸腺胸腺 腫摘出術を施行した。体位は砕石位とし、剣状突起下に約 $3 \mathrm{~cm}$ の創 $(\mathrm{EZ}$ アクセスポート) +両側側胸部に 5 $\mathrm{mm}$ の 1 ポートを挿入した。CO2 送気を併用 $(8 \mathrm{mmHg})$ し、分離肺換気は行わなかった。術中、左腕頭静脈 から胸腺上極の視野は良好で、安全な血管処理と確実な胸腺上極・左腕頭静脈周囲脂肪織の切除が可能であっ た。胸腔鏡の挿入部位を剣状突起下から状況に応じて両側側胸部のポートに変更することで両側の横隔神経の 確認や手術操作が容易になった。手術時間 288 分、出血量 $12 \mathrm{ml}$ で術中、術後とも問題なく術後 4 日目に退院、 鎮痛薬としてアセトアミノフェン $(1500 \mathrm{mg} /$ 日)を 2 週間投与後術後疼痛は消失した。病理組織診断で B 2 胸腺 腫、正岡分類 I 期と診断された。【結語】剣状突起下アプローチは頸部領域を含めた視野が良好で安全に胸腺周 囲脂肪組織の切除が可能となり術後疼痛も少ない点からよい方法と考えられた。 


\title{
V 13-8
}

\section{胸腔鏡下に切除した転移性助骨睡場の 1 例}

\author{
○舘 秀和、田中 亨 \\ 関西電力病院 呼吸器外科
}

【緒言】胸腔鏡下手術は肺悪性腫瘍、良性肺腫瘍以外にも広く応用されている。転移性骨腫瘍に対する胸腔鏡下 切除を経験した。胸腔鏡を併用することで、皮膚切開・胸壁筋切開範囲を縮小することができ、低侵襲な手術 を行うことが可能であった。【症例】 81 歳男性【既往歴】直腸癌、腎臓癌【現病歴】腎臓癌手術後、経過観察 中に CT で右第 6 胁骨に $35 \mathrm{~mm}$ 大の骨融解像を伴う腫瘍腫瘤陰影が出現した。CT ガイド下生検で腎臟癌の骨 転移と診断した。泌尿器科と治療方針を確認し、腫瘍摘出の予定となったが、高齢であり皮虐切開範囲が少な い胸腔鏡下に行う方針とした。【手術所見】第 9 肋間から胸腔鏡を挿入し、胸腔内を観察して胁骨腫瘍の位置を 確認した。第 6 肋骨切除のための皮虐切開を前胸部と肩甲骨下に置いた。胸腔鏡を併用し胁骨を胁間筋から剥 離し、胁骨切断を行った。手術時間 140 分、出血量 $16 \mathrm{ml}$ であった。【経過】術後経過良好で術後 4 日目に退院 となる。【結語】肋間筋以外の胸壁筋浸潤を認めない胁骨腫瘍切除に際して、胸腔鏡を併用することは皮虐皮下 組織と胸壁筋への損傷軽減に寄与すると考える。 


\title{
V14- 1
}

\section{後方浸潤を主体とする SST に対する傍㾑柱弧状切開による助 骨切除と胸腔鏡補助下肺門処理}

\author{
○田川 努、持永 浩史、徳永 隆幸、辻 博治
}

国立病院機構長崎医療セン夕一 呼吸器外科

【目的】後方浸潤を主体とする Superior sulcus tumor (SST) の切除では、高位後側方切開による切除が一般的 である。傍脊柱弧状切開による肋骨切除と胸腔鏡補助下肺門処理にて胸部筋肉および骨性胸壁の損傷軽減と機 能温存を目的に胸腔鏡を利用した低侵襲アプローチで切除を行っているので報告する。【症例 1 】 72 才、男性、 左肺上葉扁平上皮癌、第 $2,3,4$ 肋骨浸潤あり、cT3N0M0, stageIIB。手術は傍脊柱弧状切開に 3 ポートで左 肺上葉切除、第 $2,3,4$ 肋骨切除、肺門・縦隔リンパ節郭清施行した。手術時間 : 6 時間 40 分, 出血: $490 \mathrm{~g}$ 【症例 2】 84 才、男性、左肺上葉多形癌、第 $2,3,4$ 肋骨浸潤あり、cT3N0M0, stageIIB。手術は傍脊柱弧状 切開に $11 \mathrm{~cm}$ 側方切開を加え、2 ケ所の開胸で左肺上葉切除、第 $2,3,4$ 肋骨切除、肺門・縦隔リンパ節郭清施 行した。手術時間 : 5 時間 43 分, 出血 : $570 \mathrm{~g}$ 。【結果】手術の特徴は胸腔鏡補助下に肺動静脈・気管支切離、 肺門・縦隔リンパ節郭清を行い、浸潤胁骨直上に最小限の皮膚切開を挔き肋骨切除し同部より病変を取出す。 通常の手術であれば後側方切開開胸のように長い皮虐切開と肋間開胸、広背筋や前鋸筋の切離を必要とする手 術であるが、胸腔鏡を利用することにより、より小さな皮虐切開で胸部筋肉の切離と長い肋間開胸をせず切除 できた。特に広背筋は後に筋弁として利用することが可能であり、予期せ女合併症時に有効利用できる。また 胸壁浸潤範囲を胸腔内から観察し切除予定線を明確に決定できる利点もある。【結論】肺門部胸腔鏡補助下処理 と浸潤胸壁直上の最小限皮膚切開により、胸壁損傷の少ない低侵襲手術が可能である。 


\section{14-2}

\section{高位背側胸壁浸潤癌に対する胸腔鏡・直上小切開併用アプロー チによる胸壁合併切除}

○萩原 優、小野 祥太郎、福田 賢太郎、牧野 洋二郎、垣花 昌俊、梶原 直央、大平 達夫、 池田 徳彦

東京医科大学 呼吸器・甲状腺外科学分野

【背景】骨性胸郭への浸潤を伴う原発性肺癌に対する根治切除術は、胸壁合併切除を伴うため通常開胸手術によ り行われる。高位背側胸壁合併切除の場合、高位後側方開胸（Paulson 法）など開胸創を拡大するアプローチ が一般的で、胸郭を大きく開大させ操作性、視認性を確保している。切除後の創は胸壁切除部から胁間開胸部 分に続く大開胸創となり、胸郭へのダメージは大きく、術後疼痛も強い。当科では侵襲および疼痛の低減のた め、胸腔鏡下操作を併用し、切除胸壁の直上に開胸創を限局する方法で胸壁合併切除を行っている。【目的】当 科で施行した胸腔鏡・直上小切開併用アプローチによる胸壁合併切除の 2 例の手技、手順など、動画にて供覧 する。【症例】1）63歳男性、左上葉原発の cT3N0M0 stageIIB の腺癌。腫瘍は肋横関節近傍に及ぶ第 2 4 後胁骨へ浸潤。2) 76 歳女性、左上葉原発の cT3N0M0 stageIIB の腺癌。腫瘍は第 $2 \sim 3$ 後胁骨へ浸潤。【手術】 2 例とも 4 ポートでの胸腔鏡下操作により肺門処理を先行し肺の可動性を確保した後、胸腔内から胁間筋の切 離など、骨の切断以外の胸壁切離操作を可及的に行った。浸潤部直上には頭尾側方向に約 $10 \mathrm{~cm}$ の皮切を加え 骨性胸郭に達し、浸潤範囲を胸腔内所見と合わせて確認し肋骨を切断、胸壁と左肺上葉を en-blockに摘出し た。2 例とも術後経過は良好で、術後 1 か月には鎮痛剂不要となっている。【考察】本アプローチは浸潤部を直 視で確認することはできないが、胸腔鏡により浸潤部の視野はむしろ良好に得られる。浸潤範囲など一定の条 件のもとでは、胁間の開大を要する開胸操作を行わずに施行することができ、侵襲、疼痛の低減への貢献が期 待される。 


\section{V14-3}

\section{術前導入療法後の肺尖部胸壁浸潤癌に対して行った胸腔鏡・開 胸融合手術の 1 例}

○出嶋 仁、黒田 浩章、坂田 省三、有村 隆明、水野 鉄也、坂倉 範昭、坂尾 幸則 愛知県がんセンター中央病院 呼吸器外科部

当院では 2012 年以降積極的に胸腔鏡手術を導入しており現在は約 380 例/年の手術症例のうち約 7 割に胸 腔鏡手術を行っている。ただ術前にリンパ節転移の疑う症例（cN1-2）または局所進行肺癌（cT2a-4）に対し ては手術の安全性や腫痬学的根治性のために開胸手術を基本としている。しかし局所進行肺癌の手術は時に過 大な手術侵襲を伴うことがあるため、胸腔鏡手術を融合することによって安全性と根治性を保ちつつ手術侵襲 の軽減を図る工夫をしている。2014 年より肺尖部胸壁浸潤癌、腫瘍感染を繰り返す巨大肺癌、横隔膜浸潤癌、 前方縦隔浸潤癌の 4 例に対して施行しており今回はその中の 1 例につきビデオを供覧する。6 0 歳代男性、左肺 尖部前方浸潤癌（cT3N2M0, stageIIIA）。放射線化学療法 $(C D D P+V N R \times 2$, RT40Gy）後に ycT1bN2M0, stageIIIA の評価で手術を行った。放射線化学療法後の肺尖部操作と肺門部の転移リンパ節郭清を同時に行う ためには hemi-clamshell 開胸による door-open method が必要であったが、肺尖部操作に胸腔鏡を用いること で側方開胸のみで施行可能であると判断した。手術は胸腔鏡先行で開始した。開胸の視野で肺尖部は胸腔内の 最深部にあたり、視野と作業スペースを確保するために大開胸が必要となるが、胸腔鏡では死角に回り込みか つ拡大視ができるため手術操作を安全かつ確実に進めることができた。開胸へ移行した後は肺動脈本幹を確保 し安全に肺門部の転移リンパ節郭清をおこなう事ができた。また、創も約 $10 \mathrm{~cm}$ 程度の側方開胸のみで行え た。病理所見は pathological CR であり、現在は追加治療なく 1 年経つが無再発である。複雑化する呼吸器外科 手術に対してさまざまな手技に精通し適切に行うことが求められる。 


\section{14-4}

\section{VATS を適応した低侵襲拡大手術-TMA と VATS アプロー チで切除した肺尖部胸壁浸潤癌の 1 例-}

$\bigcirc$ 奥村 典仁、大月 康弘、中園 千晶、本多 陽平、田崎 拓朗、山梨 恵次、高橋 鮎子、中島 尊、 松岡 智章

倉敷中央病院 呼吸器外科

近年、肺尖部胸壁浸潤癌（SST）で適応される事が多くなった Transmanubrial approach（TMA）は鎖骨や 胸鎖関節の離断を要せず、筋肉切断量も少ないそれ自体は低侵襲なアプローチであるが、一般に肺門処理には 他の開胸法の併施を要する。今回 cIIIB 期 SST に対して導入化学放射線療法後に TMA と VATS アプローチ で完全切除を行い、術後の良好な QOL と長期無再発生存が得られている症例を経験したので報告する。症例】 56 歳男性。左肩痛と左上肢㾝れ感にて当院へ紹介。PET/CTにて左肺尖部に第一胁骨の融解と FDG 高集積を 伴う 65mm 大の腫瘤ならびに LN \#-6 6 に FDG 集積を伴う腫大リンパ節を認めた。造影 CT および MRIにて 鎖骨下動脈、腕神経叢（Th1）への浸潤も疑われた。気管支鏡にて非小細胞肺癌の診断（cT4N2M0）。CBDCA +PAC 3 コースおよび 50Gy の同時化学放射線療法を施行した後に手術を施行。【手術】右側臥位で左腋窩に約 $4 \mathrm{~cm}$ の皮切と 2 ポートでVATSを開始。Resectability 確認後、胸壁浸潤部を残して、左上葉の血管・気管 支・葉間の処理と ND2a 郭清を完了。続いて体位を仰臥位とし TMAを行なった。浸潤の疑われた鎖骨下動 脈・腕神経叢は剥離が可能であり、腫瘍とマージンをとって第 $1 \cdot 2$ 肋骨を含む胸壁を合併切除し、左上葉を摘 出した。術後病理診断では切除断端陰性、y-pT1bN0M0（EF2）であった。術翌日から上肢の挙上は可能であ り、術後 1 週間で軽快退院。術後約 3 力月後に遅発性乳糜胸で再入院となったが、その後は経過良好で術後 5 年の現在、無再発で復職している。 


\title{
V 14-5
}

\section{拡大手術と眴腔鏡下手術のコラボレーション}

\author{
○西田 達、三上 厳、藤井 祥貴、竹内 千枝
}

石切生喜病院 呼吸器外科

【はじめに】hook approach や hemi - clamshell approach は適応範囲が広く、体位変換を行わずに良好な術野を 確保できる優れたアプローチである。我々は肺尖部胸壁浸潤肺癌や中縦隔腫瘍のような外科切除に対し、これ らのアプローチに定型化した胸腔鏡下手術をコラボレーションすることで、さらに良好な手術操作が可能にな ると考えており、その実際をビデオで供覧する。【症例 1】56 歳男性。H24.9 月、胃穿孔に対し他院にて緊急手 術。術直後より右肩関節痛を訴えていたが、NSAIDsにて経過観察されていた。H25.2 月、症状が増悪したため 胸部 CT を施行。右肺尖部を首座とし胸椎へ浸潤する $8 \mathrm{~cm}$ 大の塊状影が検出され、H25.3 月当院紹介受診。 TBB にて肺腺癌と診断され、化学療法 $(\mathrm{CBDCA}+\mathrm{PTX}$ ：3 コース）と放射線療法 40Gy を先行。胸腔鏡下手術にて 胸腔内の観察と血管の露出を行った後、hook approach にて右上葉切除・胸壁合併切除（第 1-4 肋骨、小胸 筋）、胸椎浸潤巣掻爬、胸壁再建を施行した。【症例 2】63 歳男性。H27.11 月上旬、咳嗽を主訴に近医を受診。 胸部異常陰影を指摘され、精查加療目的に当院紹介受診。胸部 CT で中縦隔に $8 \mathrm{~cm}$ 大の塊状影を検出、 TBB にて胸腺癌と診断され、化学療法 $(\mathrm{CBDCA}+\mathrm{PTX}: 2$ コース) 先行。胸腔鏡下手術にて胸腔内の観察と中縦隔 腫瘍背部の剥離および奇静脈弓切離を行った後、hemi-clamshell approach にて胸腺癌摘出、SVC・奇静脈弓 合併切除およびSVC 再建を施行した。【結語】肺尖部胸壁浸潤肺癌や中縦隔腫瘍に対し hook approach や hemi - clamshell approach に定型化した胸腔鏡下手術をコラボレーションすることで、さらに良好な手術操作 が可能になると考える。 


\section{V14-6}

\section{胸壁浸潤肺癌に対する完全胸腔鏡下胸壁合併切除}

\section{○森山 重治、葉山 牧夫、清水 大、柳光 剛志、梅田 響}

岡山赤十字病院 呼吸器外科

【はじめに】胸壁浸潤肺癌に対し肋骨を含む胸壁を合併切除する際必要なことは, 1) 肋間動静脈の切離，2）肋 骨の切離，3）肋骨の背側にある呼吸筋群の切離である。1）は最近のエネルギーデバイスの進歩により容易と なった。2) は我々が行っている $3 \mathrm{~cm}$ の小開胸から開胸で用いる肋骨剪刀を入れることは不可能と考えていた が, マイダスレックス (メドトロニック社)を用いて可能となった。3）については体表面からアプローチする と僧帽筋，前鋸筋，大・小菱形筋など大きな上肢の運動筋を切離しなければ骨性胸郭に到達できないが, 肋骨 に外側から付着する筋肉は前鋸筋の部分を除けば後鋸筋, 短肋挙筋など小さな筋のみで, これらを内側から切 ることができれば骨性胸郭を合併切除することが可能である。我々は完全鏡視下に第 2,3 肋骨を含む骨性胸郭 の合併切除を試みたのでビデオで供覧する。【症例】71歳, 男性。大腸癌の術前精査で左上葉に腫瘤を指摘。 結腸左半切除後当科紹介となる。肺腫瘤が急速に増大し術前には第 2 肋間筋に浸潤を認めた。第 1 肋間筋, 第 2,3 肋骨・肋間筋は完全鏡視下に切離できたが, 術中に胁骨と腫瘍が分離したため分割して切除した。【考察】 大開胸で行うと肩胛骨上縁まで切り上げ，前鋸筋，僧帽筋，大・小菱形筋など大きな胸壁筋群を切離しなけれ ばならず，術後の上肢運動に支障を来す。胸腔内アプローチでは切離マージンが一目で分かり, 切離する筋も 最小限で済み侵襲が少ない。胁間動静脈の切離はエネルギーデバイスにより安全かつ容易であった。小開胸創 からの鏡視下肋骨切離は容易であった。背側筋群からの骨性胸郭の切離に課題が残った。 


\section{V15-1}

\section{当院における完全鏡視下肺区域切除}

○田尻 道彦、荒井 宏雅、椎野 王久、亀田 洋平、森田 順也 神奈川県立循環器呼吸器病セン夕一呼吸器外科

【はじめに】当院における完全鏡視下肺区域切除症例について, 臨床的特徴と術式について検討し, 手術手技を ビデオにて供覧する。

【症例】当センターにおける 2007 年 1 月から 2016 年 11 月までの呼吸器外科手術症例 3159 例を対象として検 討した。

【成績】全症例中区域切除は 166 例であった. そのうち完全鏡視下 159 例, 胸腔鏡胸補助下 4 例, 開胸 3 例であっ た.

完全鏡視下区域切除術の対象疾患は原発性肺癌 123 例, 炎症性肺疾患 14 例, 転移性肺腫瘍 14 例, 良性結節 5 例, その他 3 例であった.

多かった切除区域は上大区 38 例, 左 S1+2 25 例, 舌区 20 例, 右 S6 22 例, 右 S2 19 例, 左 S6 13 例であった. 複合区域切除は 14 症例に施行した.

原発性肺癌に対する完全鏡視下区域切除の手術時間は $231.9 \pm 61.8$ 分, 出血量は $21.3 \pm 33.1 \mathrm{ml}$ であった

【手技】従来, $5 \mathrm{~mm}$ スコープを使用し 4 ポートから行っていたが，最近では $3 \mathrm{~mm}$ スコープを用いた Needlescopic VATSを, Wound Retractor, 3mm ポート, $2 \mathrm{~mm}$ ポートを使用した 3 ポート法で行っている. 基本的 に鉗子は $2 \mathrm{~mm}$ 鉗子を使用している。 区域間形成は，中枢側を鈍的剥離したり電気メス，エネルギーデバイス を用いて形成した後に, 末梢側を stapler を使用して形成している. 区域肺動静脈の露出は, 基本的には葉間か らアプローチして行うが, S10などでは下肺静脈から追求することもある.

【ビデオ】完全鏡視下肺区域切除症例のうち，代表的症例をビデオにて供覧する. 


\section{V15-2}

\section{低侵襲のための完全鏡視下肺区域切除の取り組み}

○浜川 博司、坂之上一朗、伊達 直希、齋藤 伴樹、南 和宏、高橋 豊 神戸市立医療センタ一中央市民病院 呼吸器外科

【はじめに】低侵襲性を求めるため、2012 年より完全鏡視下区域切除を行っている。当院の区域切除適応のコ ンセプトは、“低侵襲”であるので、低肺機能、併存する重篤な合併症、複数区域を切除する必要がある多発 GGN や転移性肺腫瘍症例等を対象としている。原発性肺腫瘍に対する標準術式は、あくまでも肺葉切除である と言う立ち位置により、電気入入を用いた完全区域間切離は行わず、肺動静脈\&気管支処理の後、自動縫合器 を用いた肺実質切離を行っている。【区切のまとめ】 $\mathrm{n}=97$ 、年齢 $66.1 \pm 11.1$ 歳、男/女 $=47 / 50$ 、原発性肺癌/

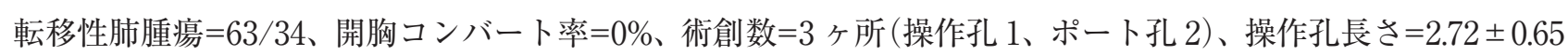
$\mathrm{cm}$ 、手術時間 $=188.9 \pm 55.5$ 分、出血量 $=16.8 \pm 31.3 \mathrm{ml}+\mathrm{g}$ 、【葉切のまとめ】 $\mathrm{n}=281$ 、同一時期の肺葉切除では、 操作孔長さ $=3.02 \pm 0.85 \mathrm{~cm}$ 、手術時間 $=164.6 \pm 60.8$ 分、出血量 $=29.8 \pm 53.2 \mathrm{ml}+\mathrm{g}$ 【結果】 区切 vs 葉切では、手術 時間は、葉切が短く $(\mathrm{p}<0.001)$ 、出血量と最長創長さは、区切が有意に少なく $(\mathrm{p}<0.01)$ 短かった $(\mathrm{p}<0.001)$ 。 【結語】当院では胸壁合併切除を除くほほ全ての肺切除症例に対し完全鏡視下手術を心がけている。幾つかの手 術を供覧し、手技をより磨き上げる為のご意見を頂きたいと考えています。 


\section{V15-3}

\section{胸腔鏡下肺区域切除における合気虚脱線作製の工夫}

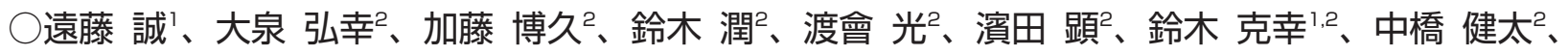
鑓水 佳? 捧 貴幸 2 塩野 知志? 、貞弘 光章 ${ }^{1}$

'山形県立中央病院呼吸器外科、年山形大学医学部 第二外科

【背景】解剖学的肺区域切除術では坪田らが報告した切除側含気法が広く用いられている. Slip knot 法（以下 SK 法）による切除側含気法は大泉らが報告した区域切除術の補助手段で，利点は HFJV や細径気管支鏡など の設備が不要で, 術中気管支鏡が容易に行えない状況でも術野からの操作のみで含気虚脱線の描出が可能な事 である.【方法】2010 年以降に SK 法を導入して以来, 区域切除 221 例を経験した. 後方視的に臨床背景を解析, 適応と課題を検討する。【結果】SK 法の適応症例は 147 例 $(67 \%)$, 非適応症例は 74 例 $(33 \%)$. 非適応理由は 定型的区域切除 (肺底区，S6，上大区，舌区) が 30 例，腫瘍局在が明らかで区域間肺静脈のみで区域切除可能 な症例 11 例, 肺気腫 4 例, 炎症癒着 3 例, 気管支内病変 2 例, その他 24 例. SK 法適応 147 例の $96 \%$ で良好 な含気虚脱線の描出を得た。描出困難症例は 5 例，原因は慢性気管支炎による喀痰貯留 2 例，切除予定肺の炎 症性変化 1 例, 肺気腫 1 例, CCAM1 例.【結語】SK 法は定型的区域切除より小さい範囲の区域切除や帚区域 切除で適応されていた. 炎症性変化や肺気腫例では含気虚脱線描出が不十分になることが課題である. SK 法を 用いた肺区域切除術をビデオにて供覧する。 


\section{V15-4}

\section{区域間結合織切離による左肺 S10に対する胸腔鏡下解剖学的 肺区域切除術}

○玉里 滋幸、五明田 匡、太田 紗千子、吉村 誉史、寺田 泰二 京都桂病院呼吸器セン夕ー 呼吸器外科

【背景】当科では術前に肺動静脈と気管支の走行を 3D-CT で確認し、気管支の分岐部から区域間静脈に沿って 区域間結合織を切離する解剖学的肺区域切除術を行っている。この術式で施行した、左肺 S10 の胸腔鏡下解剖 学的肺区域切除術を提示する。症例】症例は 75 歳男性。胸部 CT で左肺 S10a に $10 \mathrm{~mm}$ の増大傾向のある GGN を指摘された。【手術方法】第 5 肋間前腋窩線上に $4 \mathrm{~cm}$ の小開胸と、第 7 肋間中腋窩線上と肩甲下角にそれぞ れポートを作成して完全鏡視下で手術を施行し、術中迅速病理診で肺癌の診断を得た。A10を結紮切離して、 B6 と B10 の分岐部から末梢に向けて区域間結合織を鈍的に分け、さらに背側から V $6 \mathrm{c}$ の下縁に沿って中枢か ら末梢に切離した。術前の CT で腫瘍と V6c の距離が $2 \mathrm{~cm}$ 以下であったため、 surgical margin を確保するた めに胸膜直下の S6c の一部を切り込む形で自動縫合器にて切離した。続いて同様の手順で S9 と S10 の区域間 を, B9 と B10の分岐部からの切離と V9 の背側面での切離で作成した。B10 と V10 をそれぞれ自動縫合器で切 離し、S10 を摘出した。S6 の区域間面からの leak は無く、S9 の区域間面から 2 か所の minor leak は 3-0 Vicryl で縫合閉鎖し、フィブリン糊やシートは不要であった。術後経過は良好で、術後 3 日にドレーンを抜去し、術 後 9 日に軽快退院した。病理組織診断は adenocarcinoma in situ でpT1aN0M0 であった。【結語】肺動静脈と 気管支の走行を術前 3D-CT で確認して区域間面を術前に把握できれば，区域間結合織の切離で完全鏡視下で も正しい解剖学的区域切除を行うことが可能である。 


\title{
V15-5
}

\section{胸腔鏡補助下右 S3 区域切除術一区域間静脈末梢剥離 \& ICG 溶 液区域気管支注入による区域間面同定精度向上の工夫一}

\author{
○原田 匡彦、奥井 将之、浅川 文香、堀尾 裕俊
}

がん・感染症センター都立駒込病院 呼吸器外科

【症例】 77 歳女性呼吸苦契機発見の肺癌疑い c-T1aN0M0 stage IA、低肺機能（FVC1.421，FEV1.0 1.061）で消 極的に右 S3 区域切除施行。区域切除病変は HRCT で rt.S3b 未梢 $12 \mathrm{~mm}$ consolidation TDR=0.75 未確診。【手 術】前側方切開\#4 肋間開胸 hybrid VATS、PL0E1 (-) 確認、V1-3 を末梢へ追いV1，2，3 をテーピング。V 2a，V2b，V2c を確認し V2c 末梢へ剥離しつつ S2-3 間肺実質を切離。V1a，V1b 分岐確認後 V1b 未梢へ剥離 しつつ S1-3 間肺実質を切離。 V3 を切離、葉間 asc A3a と前方 A3b を確保後切離。 \#10, 11s, 12uLN を廓清 しつつ(迅速陰性確認)右上葉支を末梢へ剥離、B3 確保し中枢結紮・末梢解放切離、末梢側に 4-0 prolene stay suture をかけ切離端より $10 \mathrm{ml}$ シリンジ $18 \mathrm{G}$ サーフロー外套を装着し ICG25mg + 生食 $100 \mathrm{ml}$ 溶解液を B3a, B $3 \mathrm{~b}$ に半量づつ注入、切除肺染色した上で区域間ラインを凝固 100\% 電気メスで焼灼切離、S2 側に若干切り込ん だため V2c 切離し標本摘出。\#2R-4R, 7 を廓清。術後肺瘦予防の為タコシール貼付 $19 \mathrm{Fr}$ Blake drain 挿入し閉 創。2h59min 120g 8POD 抜管 11POD 退院。rt.S3b 7mm Ad. mixed subtype (acinar $>$ pap $>$ BAC) G2 $>$ G3 $>$ G 1 PLOEs1 (-) D0PM0Ly0V0 標本上マージン 10mm。【考察】ICG 注入法は肺表面だけでなく肺実質の色調変化 が認められ区域間同定しやすい利点がある一方で、区域支のみならず覀区域支入口部を肉眼で確認しそれぞれ に相当量注入しないと super selective になりやすい (S3 の場合 S3a もしくは S3bのみの染色)、極めて緩徐に 注入しないと脇漏れする、症例によっては区域間静脈からのロスがあるなどの欠点がある。肺区域・亜区域間 静脈の可及的末梢剥離+肺実質切離の併用がこの欠点を補完しうると思われた。 


\section{V15-6}

\section{単孔式完全鏡視下 S6 区域切除}

○上吉原 光宏1、伊部 崇史1、河谷 菜津子'、大沢 郁1、吉川 良平1,2、矢島 俊樹²、清水 公裕 ${ }^{2} 、$ 茂木 晃 ${ }^{2} 、$ 桑野 博行 ${ }^{2}$

'前橋赤十字病院 呼吸器外科、2群馬大学外科診療センター 呼吸器外科

【はじめに】完全胸腔鏡下肺区域切除（VATS lobectomy）は，現在盛んに行われるようになってきた，当科で は以前より「Reduced port surgery」をコンセプトに，さらなる低侵襲化を目指した単孔式胸腔鏡手術（単孔 式VATS)を報告してきた，単孔式VATS は肋間神経損傷が 1 肋間に限られ，疼痛の軽減が期待できる。呼吸 器外科領域では縦隔腫瘍, 肺部分切除で単孔式 VATS の報告が散見されるが, 肺葉切除の報告はまだ少ない. 今回我々は, 単孔式完全胸腔鏡下（皮切 $3 \mathrm{~cm}$ のみ）に解剖学的肺区域切除を行ったので報告する.

【症例】 50 代, 女性. 大腸癌術後 CT でフォロー中, 8 力月後に左肺 S6 に転移巣が出現, 切除目的に当科へ紹 介された。経過観察中に増大傾向を認めたため, 外科治療の方針となった.

【手術手技】1）第 6 肋間, 中腋窩線上に $3 \mathrm{~cm}$ の皮切。 2) 主な使用器具は径 $5 \mathrm{~mm}$ フレキシブル型胸脉鏡, 径 $5 \mathrm{~mm}$ 把持鉗子・剪刀・エネルギーデバイス. 3) 葉間 $(\mathrm{S} 1+2$ と S6 の間)をエネルギーデバイスで切離. 4) 葉 間側より A6 をステイプラーで切離. 5) 前縦隔側より V6 をステイプラーで切離. 6) 切除肺を膨張させて葉間 側より B6 をステイプラーで切離. 7) 区域間を電気メス及びステイプラーで切離. 8）肺をビニールバッグヘ 入れて体外へ摘出.9）区域切離面はポリグリコール酸シートで被覆. 10) 胸腔内へ $19 \mathrm{Fr}$ シリコン製ドレーン を 1 本留置. 手術時間 147 分, 出血量 $30 \mathrm{ml}$ 未満.

【経過】翌日に胸腔ドレーン抜去し, 術後 4 日目に退院. 術後病理診断にて, 大腸癌からの転移性肺腫瘍であっ た.

【まとめ】従来の胸腔鏡用器具を使用し特殊な器具は必要としなかったが, 手技上の工夫を要した. また, 適応 に際しては，適切な症例の選択をするべきと考える. 


\title{
V16-1
}

\section{上中葉の分葉不全を伴う中葉に発生した肺癌に対して胸腔鏡下 に S3+4+5 切除を施行した 1 例}

\author{
○水野 幸太郎、田中 宏紀
}

名古屋市立東部医療セン夕一 呼吸器外科

【はじめに】右上中葉間の不全分葉を伴う中葉に発生した原発性肺癌に対し, 胸腔鏡下に右肺 $\mathrm{S} 3+4+5$ 切除を施 行し上中葉切除を回避し得た症例を報告する.【症例】63歳女性. 胸部異常影を指摘され来院. CT で右 S4 に $2.0 \times 1.7 \mathrm{~cm}$ の充実性結節を認めた. cTlaN0M0 の原発性肺癌と判断し手術予定となった. 画像上は上中葉間 が不全分葉であり, かつ腫瘍が S 3 に近いため上中葉切除が標準術式であるが, 小型肺癌であり術中迅速診断で $11 \mathrm{~s} ， 12 \mathrm{u}$ リンパ節への転移が否定されれば根治的縮小手術として S $3+4+5$ を行う方針とした.【手術】第 7 肋間後腋窩線に $3 \mathrm{~cm}$ の access port, 第 4 およよ゙ 6 肋間前腋窩線に $12 \mathrm{~mm}$, 第 6 肋間肩甲骨下角に $5 \mathrm{~mm}$ のポー トで手術を開始．葉間から上下葉間を切離して $11 \mathrm{~s}$ リンパ節を迅速診断に提出 (陰性). A4 を切離．中下葉間

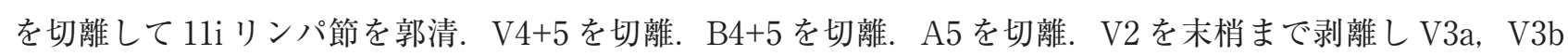

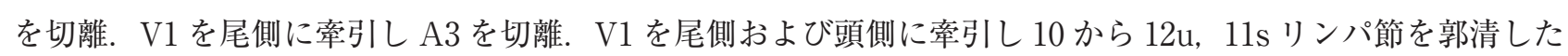
のち B3 を切離. 尾側からステープルを用いて S3 の区域間を切離し S3+4+5 を摘出. 上縦隔および 7 リンパ節 を郭清し手術を終了. 手術時間 250 分, 出血量 $30 \mathrm{~g}$.【術後経過】術後 2 日目に胸腔ドレーンを抜去し 6 日目に 退院. 病理診断は腺癌で pTla $(2.0 \mathrm{~cm}) \mathrm{N} 0 \mathrm{M} 0$ であった.【まとめ】小型肺癌の治療機会増加とともに, 根治的 縮小手術の適応を検討する症例が増えている. 本症例のように不完全分葉で 2 葉切除が考慮される症例に対し ても，胸腔鏡下に区域切除術を行うことで根治性と低侵襲性を確保でき有用と思われた. 


\section{V16-2}

\section{術前の 3D 解析が有用であった不全分葉部に発生した小型の膵 癌肺転移に対する胸腔鏡下左舌区+S8 区域切除}

○水谷 尚雄、澤田 茂樹

姫路赤十字病院 呼吸器外科

【緒言】不全分葉部に発生した転移性肺腫瘍に対し，胸腔鏡下舌区 $+\mathrm{S} 8$ 区域切除を施行した。【症例】72 歳，女 性. 膵癌術後 4 年 8 か月目に左肺 S5/8 の不全分葉部に空洞を有する $8 \mathrm{~mm}$ 大の結節が出現. 画像的には原発性 肺癌も疑ったが，B8 からの気管支鏡下生検で膵癌肺転移と診断された。【術前 3D 解析】VINCENTを用いた 解析で B5b と B8b の分枝が腫瘍に流入し, 肺動脈は底区枝から A5 が分岐し, その末梢で A8+9 と A10 に分岐 していた．CTで葉間線は背側で確認できるが，腫瘍の部位では消失していた．葉間を形成すると腫瘍に切り 込むため, 舌区 $+S 8$ 切除を予定した.【手術手技】胸腔鏡下では肺の脱転回数を少なくし, 区域間形成は血管 と気管支の走行確認を重要視している. $6 \mathrm{~cm}$ の小開胸と 3 ポートで, (1)肺門腹側で下肺静脈, $V 4+5$, 舌区及 び下葉気管支を露出，（2）肺門背側で下肺静脈を末梢まで露出，（3）葉間では不全分葉部に切り込まぬように 最小限に肺動脈を露出. A4 を切離し, 舌区気管支根部を露出, (4)肺門腹側で V4+5を切離し, 舌区気管支の 背側で A4 断端を確認後に気管支を切離，（5)末梢側から stapler で区域間を形成し，舌区を尾側へ脱転すると 底区肺動脈を露出され，（6）A5 を切離後に A8+9 をテーピングし，A8a を切離，（7）B8 と V8a， b を露出, （8）血管・気管支の走行から S8/9 間の切離予定線をマーキング，（9）A8b を切離後，含気虚脱線を確認して B8 を切離，（10）B8 断端を周囲から十分に浮かせて，その背側でV8a を切離，（11）末梢側から区域間を staplerで切離し, 術前のプラン通りに手術を完了. 術後の病理診断も膵癌肺転移であった.【結語】不全分葉部は 気管支と血管のバリエーションも多く, 術前の $3 \mathrm{D}$ 解析は大変有用であった. 


\section{V16-3}

\section{見下ろし視野が有効であった胸腔鏡下右 S9 区域切除術の 1 例}

$\bigcirc$ 三澤 賢治'、三島 修'、橋都 正洋、牛山 俊樹? 、北野 司久' '相澤病院 呼吸器外科、相澤健康セン夕ー

【はじめに】肺底区における区域切除術は、肺動脈を露出する際、葉間から深部に向かって肺実質を切開してい く必要があり、胸腔鏡下に行う際にはさまざま工夫が必要となる。今回、第 2 肋間にカメラポートおよび操作 ポートを置くことで、良好な視野を確保し、安全に手術を完遂できた胸腔鏡下右 S9 区域切除術の 1 例を経験し たので報告する。【症例】 68 歳、女性。胸部 CT にて右 S9 の不整形病変を指摘され紹介となった。TS-CT にて右 S9 に part-solid nodule を認め、FDG-PET/CTにて同部にSUVmax 1.3 の淡い集積を認めた。早期肺癌 の疑いにて手術を予定した。病変の視認掞よび触知の困難が予想された為、VAL-MAPによる術前マーキング を行った。手術手順】第 5 肋間中腋窩線/第 6 肋間前腋窩線/第 8 肋間後腋窩線にそれぞれ $3 \mathrm{~cm} / 2 \mathrm{~cm} / 2 \mathrm{~cm}$ の皮 切を置き、3 創で手術を開始した。見上げの視野にて葉間肺動脈を露出しテーピングを行った。その後、第 2 肋間に 2 本の $5 \mathrm{~mm}$ ポートを追加した。1 本をカメラポートとして、もう 1 本を操作ポートとして利用した。下 葉肺を見下ろす視野で A9、B9、V9a の順に露出、切離した。切離した B 9 断端より空気を挿入し、S8 および S10 との区域間面を作成した。見上げの視野に戻り、区域間切離を行った。切離は電気メス $(70 \mathrm{~W})$ にて行い、 切離面の処理には PGA シートとフィブリン糊を用いた。第 6 肋間より胸腔ドレーンを留置し手術終了した。手 術時間は 4 時間 41 分、出血量は $20 \mathrm{cc}$ であった。【結語】第 2 肋間に 2 つのポートを置くことで、見下ろしの視 野の確保と血管走行に沿った手術器具の挿入が可能であった。深部に向かって伸びる血管および気管支を安全 に処理することが可能であり大変有用な方法と考えた。 


\title{
V16-4
}

\section{左肺底区動眽の一部が左主肺動脈から分岐した症例に底区域切 除を施行した肺癌の 1 例}

\author{
○片岡 和彦、久保 友次郎、塩谷 俊雄
}

岩国医療センター 胸部外科

【はじめに】肺動静脈の分岐走行には破格（variation）が存在し、その可能性を念頭に置いておかないと切離し てはいけない血管を切離してしまう可能性がある。その中で左下葉肺動脈の分岐破格の報告は極めて少ない。 今回は左底区動脈の一部が左主肺動脈の第 1 枝として分岐していた肺癌に、左底区域切除を施行したので報告 する。【症例】76 才女性。検診で精査となり、CT で左 $\mathrm{S} 9$ に $1.5 \mathrm{~cm}$ の結節影と、右 $\mathrm{S} 8$ にも小結節影を指摘され た。PET では左がSUVmax 1.99、右がSUVmax 0.46 であった。術前 3DCT で左底区動脈の一部が左主肺動脈 の第 1 枝として分岐していた。完全胸腔鏡下にまず左側の手術を施行した。術中針生検で腺癌と診断された。 前方の縱隔胸膜を切開すると上下肺静脈の間に aberrant の肺底区動脈を認め、結紮切離した。通常の分岐を示 す底区の肺動静脈と気管支を切離した後に ICG を静注し、区域間をマーキングし stapler で切離した。pTlaN $0 \mathrm{M} 0$ stage1A であった。術後経過良好で、4 4 月後に右下葉の病変を胸腔鏡下に部分切除し、腺癌と診断され た。再発を認めず、PS も良好である。【考察】左下葉肺動脈の破格はまれではあるが報告されている。本症例 は左底区動脈の一部が縦隔型で独立して分岐していた。術前の 3DCT で同定していたため、安全に手術を施行 することができた。結語】左底区動脈の一部が左主肺動脈の第 1 枝として分岐するきわめてまれな肺動脈分岐 破格を伴った肺癌症例に底区域切除を施行した。術前の 3DCT が破格の同定に有用であった。 


\section{V16-5}

\section{非結核性抗酸菌症に対する胸腔鏡下右上葉切除+S6 区域切除}

○鈴木 潤、大泉 弘幸、加藤 博久、濱田 顕、渡會 光、中橋 健太、貞弘 光章、貞弘 光章 山形大学医学部 第二外科

くはじめに>非結核性抗酸菌症では、胸腔鏡下手術は低侵襲、整容性の点から良い適応となるが、癒着剥離や 剥離時の肺損傷の際の菌流出の可能性と肺門の血管新生等による易出血性など手術困難が予想される。当科で はこのような症例に対し積極的に胸腔鏡下手術を行っており、最近の 26 症例で開胸移行した症例は 1 例のみ である。<症例＞63 歳男性。B.I 840 の重喫煙者。2009 年から次第に増大する右上葉から S6 に及ぶ最大計 $8 \mathrm{~cm}$ の空洞病変。吸引痰の抗酸菌培養から M.intracelluare が検出された。7 月間の三剂併用療法 (CAM、RFP、 $\mathrm{EB}$ 後に当科紹介。<手術＞術者は患者の前方に立ち、4 ポートでアプローチした。胸腔内の密な癒着を剥離

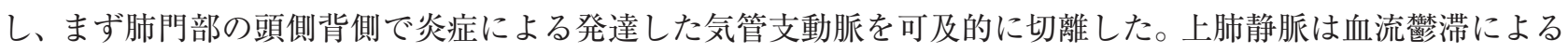

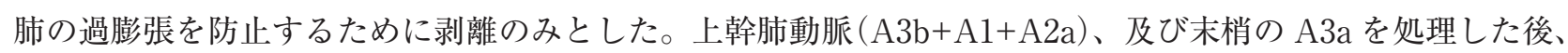
上中葉間分葉不全を自動縫合器で切開した。上葉気管支を自動縫合器で処理し。その後に $\mathrm{A} 2 \mathrm{~b}$ 、次いで上肺静 脈を処理した。中葉と S6 の癒着部を切開し、三葉合流部を明らかとした後、前方から A6、B6そしてV6a を処理した。肺を換気しおおよその区域間を確認し、V6b、c に沿って肺門側の肺実質を切開し、S6肺底区域 間を自動縫合器で切開し上葉及び S6 en-bloc に切除した。手術時間 169 分、出血量 $100 \mathrm{ml}$ 第 1 病日に胸腔 ドレーンを抜管し、第 5 病日に退院した。＜結論＞本症例のような下葉に及ぶ広範な非結核性抗酸菌症に対 し、右上葉と S6 区域の en-bloc 切除は胸腔鏡下に完遂可能であった。また出血量軽減、明瞭な術野確保のため 気管支動脈処理を先行してて行うことが肝要と考えられた。 